\title{
Simulation and Analysis Plan to Evaluate the Impact of CO Mitigation Requirements for Portable Generators
}

\author{
Steven J. Emmerich \\ Brian Polidoro \\ Matthew J. Brookman \\ Janet Buyer \\ Matthew Hnatov
}

This publication is available free of charge from: https://doi.org/10.6028/NIST.TN.2048 


\title{
Simulation and Analysis Plan to Evaluate the Impact of CO Mitigation Requirements for Portable Generators
}

\author{
Steven J. Emmerich \\ Brian Polidoro \\ Energy and Environment Division \\ Engineering Laboratory \\ Matthew J. Brookman \\ Janet Buyer \\ Matthew Hnatov \\ U.S. Consumer Product Safety Commission
}

This publication is available free of charge from:

https://doi.org/10.6028/NIST.TN.2048

June 2019

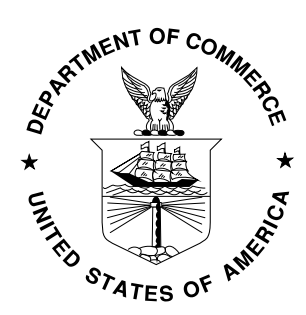

U.S. Department of Commerce Wilbur L. Ross, Jr., Secretary

National Institute of Standards and Technology Walter Copan, NIST Director and Under Secretary of Commerce for Standards and Technology 
Certain commercial entities, equipment, or materials may be identified in this document in order to describe an experimental procedure or concept adequately. Such identification is not intended to imply recommendation or endorsement by the National Institute of Standards and Technology, nor is it intended to imply that the entities, materials, or equipment are necessarily the best available for the purpose.

This technical note, coauthored by the National Institute of Standards and Technology and the U.S. Consumer Product Safety Commission staff, has not been reviewed or approved by, and may not necessarily reflect the views of, the Commission.

National Institute of Standards and Technology Technical Note 2048

Natl. Inst. Stand. Technol. Tech. Note 2048, 65 pages (June 2019)

CODEN: NTNOEF

This publication is available free of charge from: https://doi.org/10.6028/NIST.TN.2048 


\begin{abstract}
This report was written by staff of the National Institute of Standards and Technology (NIST) and the U.S. Consumer Product Safety Commission (CPSC, the Commission) under an interagency agreement $^{1}$ in support of the Commission's effort to address the carbon monoxide (CO) poisoning hazard associated with consumer use of portable generators. This report presents a plan for a computer simulation study to support CPSC staff's evaluation of the effectiveness of CO mitigation requirements that were adopted in two voluntary standards in 2018. These two standards are ANSI/PGMA G300-2018, Safety and Performance of Portable Generators (referred to as PGMA G300) and ANSI/UL 2201-2018, Carbon Monoxide (CO) Emission Rate of Portable Generators (referred to as UL 2201). Both voluntary standards have requirements for a system that will shut the generator off when specific $\mathrm{CO}$ concentrations are present near the generator. PGMA G300 also has notification requirements to alert the user of the presence of CO after the generator has shut off, while UL 2201 has a reduced CO emission rate requirement.

To support CPSC staff's evaluation of the effectiveness of these requirements in addressing the CO hazard, this report documents the plan for conducting a computer simulation study and for analyzing the output of that study. The methodology is largely similar to that used by CPSC staff to evaluate the benefits of the proposed rule issued by the Commission in $2016 .^{2}$ This simulation study will use the same forty buildings, weather conditions, and generator characteristics to study the rate at which the $\mathrm{CO}$ emitted from the generator accumulates in, transports within, and leaves the homes and detached garages for generators with and without CO safety shutoff systems. The plan includes over 900 scenarios that will be considered in all the buildings, which will require more than a million simulations and subsequent analysis of the simulation outputs.
\end{abstract}

\title{
Keywords
}

Generator; carbon monoxide; carboxyhemoglobin; CONTAM; exposure; indoor air quality; measurements; multizone airflow model; safety; simulation

\footnotetext{
${ }^{1}$ CPSC-I-17-0023.

${ }^{2}$ Proposed Safety Standard for Portable Generators, Federal Register, 81 FR 83556, November 21, 2016.
} 


\section{Table of Contents}

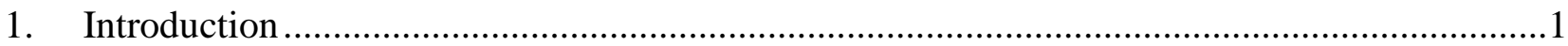

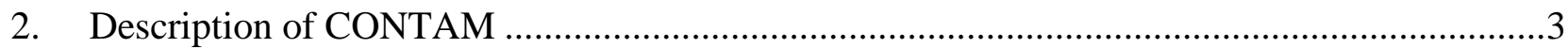

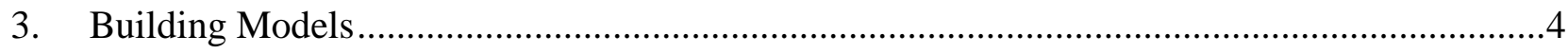

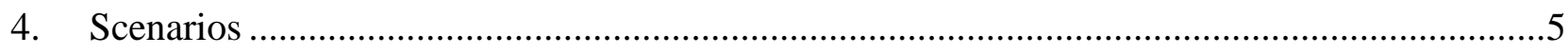

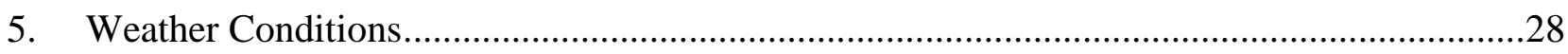

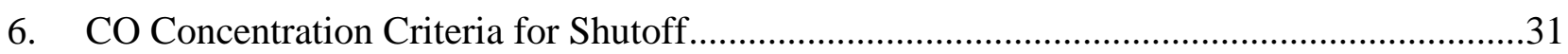

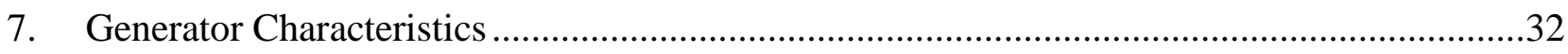

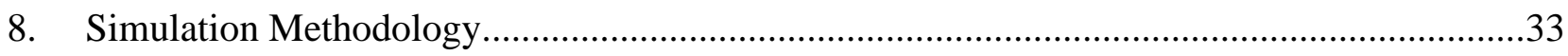

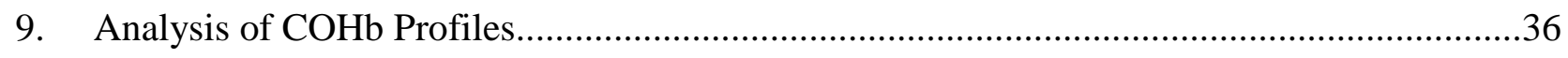

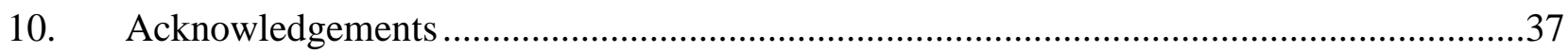

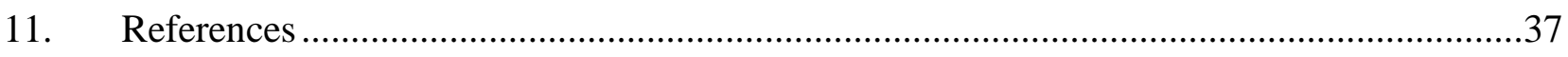

A. Modeling Output and Analysis Methodology ............................................................40 


\section{Introduction}

The U.S. Consumer Product Safety Commission (CPSC) is focused on addressing the hazard of acute carbon monoxide (CO) poisonings of consumers from portable generators that can result in death or serious and/or lasting adverse health effects in exposed individuals. As of June 27, 2018, CPSC databases contain records of at least 943 (880 from generator use alone, 63 from generator use in conjunction with another CO-producing consumer product) consumer deaths from CO poisoning associated with non-work-related use of generators in the period of 2005 through 2017 (Hnatov 2018). In addition, the percentage of estimated non-fire, consumer product-related CO poisoning deaths specifically associated with generators for CPSC's four most recent years of data are 26 \% (2010), 39 \% (2011), 42 \% (2012), and 38 \% (2013) (Hnatov 2017). Typically, these deaths occur when consumers use a generator in an enclosed or partially enclosed space or outdoors near an open door, window or vent, and they often occur after severe weather events such as hurricanes and ice or snow storms.

The initial health impact of CO is caused by anoxia: deprivation of oxygen supply. When inhaled, CO preferentially binds with the oxygen carrier in the red blood cells, hemoglobin ( $\mathrm{Hb})$, to form carboxyhemoglobin (COHb), which causes the anoxia (Stewart 1975). The COHb level reflects the percentage share of the body's total hemoglobin pool occupied by CO. In modeled acute exposure scenarios, it serves as a useful measure of expected poisoning severity in a reference individual.

The work performed previously under CPSC-I-15-0024, documented in National Institute of Standards and Technology (NIST) Technical Note (TN) 1925 (Emmerich et al. 2016), involved a computer simulation study conducted to provide CPSC staff with information to support estimations of modeled residential CO exposures reflecting operation of current designs of portable engine-driven electric generators, inside homes or in attached garages. These results were compared to simulated operation of generators with reduced CO emission rates so that CPSC staff could estimate the effectiveness of the reduced CO generators in preventing deaths that occurred with current generators. CPSC staff then recommended specific reduced CO emission rates as performance requirements to the Commission in a briefing package for a notice of proposed rulemaking (NPR) as the means to address the $\mathrm{CO}$ hazard associated with portable generators. The Commission subsequently voted to approve the NPR. (Proposed Safety Standard for Portable Generators, Federal Register, 81 FR 83556, November 21, 2016.). These previous NIST simulations employed the multizone airflow and contaminant transport model CONTAM, which was applied to 40 buildings (37 houses and 3 detached garages, considered representative of many of the fatal CO poisoning incidents reported in CPSC databases) that are based on a collection of building models representative of the U.S. housing stock (Persily et. al. 2006).

After CPSC issued the NPR, two different industry voluntary standards were published in 2018 to address portable generator CO safety: ANSI/PGMA G300-2018, Safety and Performance of Portable Generators (referred to as PGMA G300) and ANSI/UL 2201-2018, Carbon Monoxide (CO) Emission Rate of Portable Generators (referred to as UL 2201). 
PGMA G300 includes a requirement for generators to be equipped with an onboard CO sensor. Such a device, when tested to the requirements in the standard, must shut the generator off before the $\mathrm{CO}$ concentration measured at a location one inch to two inches above the approximate center of the portable generator's top surface exceeds either a rolling 10 minute average of $400 \mathrm{ppmv}$ of CO or an instantaneous reading of 800 ppmv. PGMA G300 also requires notification after a shutoff event, which is required to be a red indication. The standard also requires that this notification remain for a minimum of 5 minutes after shutoff occurs unless the generator is restarted. PGMA G300 also requires a label about the automatic shutoff in close proximity to the notification indicator, instructing the consumer about moving the generator to an outdoor area and seeking medical help if feeling sick.

UL 2201 includes a requirement of a maximum weighted CO emission rate of 150 grams per hour $(\mathrm{g} / \mathrm{h})$ and a requirement for the generator to shut off when the CO concentration one foot above the centerline of the top of the generator registers either an average of $150 \mathrm{ppmv}$ of CO for a 10minute period or an instantaneous reading of $400 \mathrm{ppmv}$.

To estimate the expected impact of these requirements on CO exposure, this report documents NIST's and CPSC's plan for conducting a new computer simulation study using CONTAM and for CPSC staff to analyze the output to arrive at estimates of effectiveness for the voluntary standards. The methodology developed for NIST TN 1925 will be used as the basis for these simulations. The planned study will include the same forty buildings and weather conditions, which will be used to study CO levels within the buildings for generators with and without CO safety shutoff systems. Simulations will also consider different occupant behaviors after a shutoff system turns the generator off.

This report describes the planned approach to perform the simulations, including descriptions of CONTAM; the building models; the scenarios for each group of building models, including the generator location and ventilation conditions; the weather conditions; the CO concentration criteria for shutting off the generator; and the characteristics of the different generator sizes that will be simulated in the building models, in terms of CO emission rates, run times on a full tank, and heat release rates. These factors affect the rate at which the $\mathrm{CO}$ emitted from the generator accumulates in, transports within, and leaves a building, and thus affects the simulated occupants' $\mathrm{COHb}$ profiles. This report also describes how the COHb profiles determined from CONTAM's predicted $\mathrm{CO}$ concentration profiles will be calculated and the manner in which the COHb data from the simulations will be analyzed by CPSC staff to estimate the effectiveness of the voluntary standards. 


\section{Description of CONTAM}

Indoor CO concentrations will be calculated in the planned study using the multizone airflow and contaminant transport model CONTAM (Dols and Polidoro 2015). CONTAM is a simulation tool for predicting airflows and contaminant concentrations in multizone building airflow systems. When using CONTAM, a building is represented as a series of interconnected zones (e.g., rooms), with the airflow paths (e.g., leakage sites, open doors) between the zones and the outdoors defined as mathematical relationships between the airflow through the path and the pressure difference across it. Outdoor weather conditions are also input into CONTAM, as they are key determinants of pressure differences across airflow paths in exterior walls. System airflow rates must also be defined to capture their effects on building and inter-zone pressure differences. These inputs are used to define mass balances of air into and out of each zone, which are solved simultaneously to determine the inter-zone pressure relationships and resulting airflow rates between each zone, including the outdoors. These airflow rates can be calculated over time as weather conditions and system airflow rates change. Once the airflows are established, CONTAM can then calculate contaminant concentrations over time in each building zone based on contaminant source characteristics and contaminant removal information, such as that associated with filtration. CONTAM has been used for several decades, and a range of validation studies have demonstrated its ability to reliably predict building air change rates and contaminant levels (Emmerich 2001, Emmerich et al. 2004, Poppendieck et al. 2016). Emmerich and Dols (2016) report a validation study that specifically evaluated the model's capability to predict CO concentrations in a test house from portable generator operation over relatively long run times in an attached garage.

CONTAM assumes that the concentration of a contaminant (CO in this study) is uniform within each zone. This was a reasonable assumption for the simulations performed in NIST TN 1925 given that the generator run time was dependent on the fuel consumption and capacity rather than being linked to a single-point value of CO. For the analysis of CO safety shutoff requirements, however, the assumption of uniform concentration may not be valid for the prediction of the run time before shutoff because the distribution of CO may vary within the space while the generator is operating. A non-uniform concentration of $\mathrm{CO}$ in the space around the generator can affect the time to shutoff since the shutoff sensor is at a single location. Distribution of CO in a space is dependent on multiple factors such as where the generator is located within the space, how the exhaust is oriented relative to surfaces that the exhaust stream comes into contact with and how close that surface is to the generator, and the velocity and temperature at which the exhaust jet exits the tailpipe. For example, in many cases, a generator operating in a room will create higher $\mathrm{CO}$ concentrations downstream of the exhaust jet while operating. This non-uniformity of CO in the space where a generator with a CO safety shutoff device is operating may result in longer run times when compared to the same scenario where the $\mathrm{CO}$ is assumed to be uniformly distributed. Increased run-time will result in increased mass of $\mathrm{CO}$ emitted and, for a given set of ventilation and leakage conditions in a building where the generator is operating, this will create higher $\mathrm{COHb}$ profiles compared to when the generator shuts off more quickly. Therefore, the simulations planned for this study will account for non-uniformity of $\mathrm{CO}$ so that reasonably accurate $\mathrm{CO}$ levels and the resulting runtimes before shutoff can be predicted by CONTAM and then be relied 
upon to estimate $\mathrm{COHb}$ profiles. The manner in which non-uniform $\mathrm{CO}$ concentrations will be accounted for are discussed in section 8.

\section{Building Models}

The house models used in the simulations are from a collection of dwellings that were previously defined by Persily et al. (2006), which includes just over 200 dwellings that together represented $80 \%$ of the U.S. housing stock. Those dwellings are grouped into four categories: detached (83 homes), attached (53 homes), manufactured (4 homes) and apartments (69). The definition of that set of dwellings was based on the following variables using the US Census Bureau's American Housing Survey (AHS) (HUD 1999) and the US Department of Energy's (DOE) Residential Energy Consumption Survey (RECS) (DOE 2005): housing type, number of stories, heated floor area, year built, foundation type, presence of a garage, type of heating equipment, number of bedrooms, number of bathrooms, and number of other rooms. In addition to defining the dwellings, multizone representations were created in the airflow and contaminant transport model CONTAM to support their use in analyzing a range of ventilation and indoor air quality issues. The project files and floor plans can be downloaded at the CONTAM website https://www.nist.gov/el/energy-and-environment-division-73200/nist-multizonemodeling/download-contam under Case Studies.

Based on the CPSC analysis of CO poisoning death incidents from 2004 through 2012 (Hnatov 2015), a subset of the NIST suite of homes collection described above (in some cases with modifications) was used in the analysis presented in NIST TN 1925 and will be used again in this study. Appendix A of NIST TN 1925 summarizes the characteristics of these dwellings and identifies the corresponding CONTAM project file name and associated floor plan. As discussed in NIST TN 1925, these files were modified for the purposes of that analysis. The subset of homes includes 31 detached house (DH) models, 4 attached house (AH) models, and 2 manufactured house $(\mathrm{MH})$ models, which reflect the modifications made to the models as described in Appendix B of NIST TN 1925. Additionally, 3 new detached garage (GAR) buildings were defined in NIST TN 1925 and included 2 single-zone garage/sheds (1 car size and 2 car size) and 1 larger garage/shed with a separate work space inside. These detached garages will also be used for this analysis. These same homes and garages were used in the benefits analysis for the NPR; more information on how these particular buildings were selected and the incident data used as the basis of this analysis are provided in TAB K of the briefing package of the NPR (CPSC Staff Briefing Package 2016).

\subsection{Air Handling System Operation}

While the homes in the NIST suite of homes collection include air handling systems for heating and cooling, this analysis will assume that the forced-air distribution systems are not operating. This is consistent with the CPSC analysis of the CO incident reports, which typically do not include incidents where the generator was used to operate the central HVAC system. Similarly, all local exhaust fans (kitchen and bath) will also be assumed to be off. 


\subsection{Door and Window Positions and Sizes}

Interior doors will be fully open during the simulations and all exterior doors and windows will be fully closed, with exceptions noted in the specifics of the scenarios, discussed in section 4. Open interior and exterior doors will be modeled with openings of $2.1 \mathrm{~m}$ high by $0.9 \mathrm{~m}$ wide (or smaller opening width as specified in the scenario descriptions). Fully open windows will be modeled with openings of $0.8 \mathrm{~m}$ high by $0.5 \mathrm{~m}$ wide. All open garage bay doors, whether attached to a house or on a detached garage, will be modeled with openings of $2.0 \mathrm{~m}$ high by $2.4 \mathrm{~m}$ wide.

\subsection{Indoor Air Temperatures}

As with the NIST TN 1925 study, temperature distributions within the simulated buildings will be calculated using a version of the CONTAM model with the ability to also model heat transfer (Emmerich 2006, Wang et al. 2012). This model accounts for heat transfer through the building envelope and for the heat produced by the generator, resulting in more realistic spatial and temporal temperature variations in the buildings. The generator heat source will vary depending on the generator size, as described in section 7.

\section{Scenarios}

This section describes the scenarios that will be used in the simulations, as defined by the type of house, the location (and exhaust direction in some cases) of the generator upon initial startup, and possible consumer responses to shutoff.

The houses are divided into 5 groups, with each group defined by whether the house has a basement, crawlspace, or garage as shown in Table 1. The right-most column in Table1, Tables of Scenarios, refers to the tables in this report describing in detail the modeling scenarios that will be run for each house group.

Table 1. Houses by Group

\begin{tabular}{|c|c|c|c|c|}
\hline House Group & Basement & Crawlspace & Garage & Tables of Scenarios \\
\hline 1 & No & No & No & 2.a. through 2.c. \\
\hline 2 & No & Yes & No & 3.a. through 3.d. \\
\hline 3 & Yes & No & No & 4.a. through 4.c. \\
\hline 4 & No & No & Yes & 5.a. through 5.d. \\
\hline 5 & Yes & No & Yes & 6.a. through 6.d. \\
\hline
\end{tabular}

Tables 2.a. through 6.d. show 121 scenarios that will be simulated for House Groups 1 through 5. These detailed scenario tables show the initial generator location within or outside the house and the initial conditions of its operation. The tables also including weighting factors that assume all 
the scenarios within a table have equal probability, with exceptions as provided in the tables. The initial locations in these tables are based on the available incident data and are discussed in more detail in Appendix A of this report, as well as how the scenario weights will be applied.

Twenty-four scenarios will also be simulated for the three detached garages. Table 7 describes the scenarios for the two single-zone garages (one car size, referred to as GAR1, and two car size, referred to as GAR2). Tables 8.a. through 8.b.ii. describe the scenarios for the larger garage with a separate work space inside, referred to as GAR3.

Each table includes scenarios in which the consumer restarts the generator after it shuts off after reaching the shutoff criteria specified in the simulation. These restart scenarios include the consumer restarting the generator in the same location where it shut off or relocating the generator elsewhere in the house or outside before restarting it. Restart locations elsewhere in the house are included for a variety of reasons as follows.

First, consumers who used their generators in indoor locations did so for one or more reasons, some of which are identified in the incident data (i.e., ignorance of the hazard; fear of theft; concern about operating the generator in wet, icy, or snowy weather conditions; concern about noise to neighbors; not having a long enough extension cord), but often the reasons were not identified. The fact that a generator shuts off due to activation of the shutoff system may not cause the consumer to take it outdoors, at least not immediately, for those same reasons. Instead, they may try to operate the generator elsewhere indoors or try to keep it running at its original location.

Second, some currently marketed generators with shutoff systems are advertised that they will shut the generator off before or when hazardous levels of $\mathrm{CO}$ are detected. The $\mathrm{CO}$ that is emitted while the generator is running, however, can result in the consumer not recognizing being exposed due to symptoms not being evident at time of shutoff. The symptoms experienced by an exposed person may not be immediately perceived but rather may be delayed until later, depending in part on the CO level reached, how quickly the CO leaves the house, and on the exposed person's general health and activity level during the exposure. For example, a vast majority of the tests documented in NIST TN 2049 (Emmerich et al. 2019) in which the shutoff algorithm shut the generator off resulted in calculated $\mathrm{COHb}$ values for simulated occupants throughout the test house at the time the generator shut off that were well below $10 \%$. Thus, exposed persons likely would not experience any perceptible CO poisoning symptoms (Burton, 1996) at the time of shutoff for these tests. Of those tests in which the COHb later rose to above $20 \%$, which is the level commonly associated with onset of perceptible symptoms such as mild headache and decreased exercise tolerance, the time interval between when the generator shut off and when $\mathrm{COHb}$ values in the house reached $20 \%$ typically ranged from about one to two or more hours, per NIST TN 2049. This imparts a reasonable expectation that some consumers may try to restart the generator after shutoff, even if they are aware (perhaps due to notification by the generator) that shutoff may be due to the presence of CO. This expectation is also based in part on incident reports in which consumers had an activated $\mathrm{CO}$ alarm but then removed the alarm batteries because they did not perceive any symptoms, which later resulted in a fatality. 
Third, another rationale for expecting some consumers to restart the generator is that UL 2201 does not have any notification requirement after a shutoff event and PGMA G300 requires the notification to last for a minimum of only 5 minutes. Regarding PGMA G300, if the consumer does not attend to the generator while a notification is present, they may not be aware that it shut off due to elevated levels of CO. This situation might occur if the consumer is not immediately aware that the generator shut off or if the generator is in a more remote location like the garage or basement.

Some scenarios in the tables specify generator exhaust direction, which as noted in section 2 can affect how quickly the generator will shut off and ultimately impact the occupant COHb profiles. The CPSC incident data rarely contains information on how the generator's exhaust was oriented, particularly relative to surfaces and doorways connecting to adjacent rooms; however, there are some incidents in which it was reported that the generator appeared to be oriented with the exhaust towards a doorway or other opening. If the generator location within the room and exhaust orientation are not specified in the tables, it is assumed that the generator's plume of high velocity exhaust remains within the source room. A discussion of how the exhaust orientation is intended to be addressed in the simulations is included in section 8 .

Table 2.a. Scenarios for Houses with no Basement, Garage, or Crawlspace with Generator Initially Operated in the Kitchen

\begin{tabular}{|c|c|c|c|c|c|c|c|c|}
\hline \multicolumn{3}{|c|}{ Structure Type: } & \multicolumn{3}{|c|}{ House } & & Basement: No & $\begin{array}{c}\text { Crawlspace: } \\
\text { No }\end{array}$ \\
\hline \multicolumn{3}{|c|}{ Initial Location: } & \multicolumn{3}{|c|}{ Kitchen (Living Space) } & \multicolumn{3}{|c|}{$\begin{array}{l}\text { Weight for Home Type: (\# deaths allocated to this } \\
\text { home } * \% \text { this location) }\end{array}$} \\
\hline \multicolumn{3}{|c|}{ Initial Conditions: } & \multicolumn{6}{|c|}{ Kitchen window is closed } \\
\hline \multicolumn{9}{|c|}{ Restart Scenarios } \\
\hline Scenario & $\begin{array}{l}\text { Scenario } \\
\text { Weight }\end{array}$ & $\begin{array}{l}\text { Sub-Scenario } \\
\text { Weight }\end{array}$ & Weight & & se to Shut & & Changes fr & Conditions \\
\hline A & $1 / 4$ & 1 & $1 / 4$ & No $\mathrm{r}$ & & & N/A & \\
\hline B1 & \multirow{2}{*}{$1 / 4$} & $1 / 2$ & $1 / 8$ & \multicolumn{3}{|c|}{ Restart in kitchen. } & \multicolumn{2}{|l|}{ None. } \\
\hline B2 & & $1 / 2$ & $1 / 8$ & \multicolumn{3}{|c|}{ Restart in kitchen. } & \multicolumn{2}{|c|}{ Kitchen window is open fully. } \\
\hline C1 & \multirow{2}{*}{$1 / 4$} & $1 / 2$ & $1 / 8$ & \multicolumn{3}{|c|}{$\begin{array}{l}\text { Restart in center of other 1st floor } \\
\text { room that has a door that isolates it. }\end{array}$} & \multicolumn{2}{|c|}{$\begin{array}{l}\text { Door to room is open } 10 \mathrm{~cm} \text {. Window } \\
\text { in room is open } 5 \mathrm{~cm} .\end{array}$} \\
\hline $\mathrm{C} 2$ & & $1 / 2$ & $1 / 8$ & \multicolumn{3}{|c|}{$\begin{array}{l}\text { Restart in center of other } 1 \text { st floor } \\
\text { room that has a door that isolates it. }\end{array}$} & \multicolumn{2}{|c|}{$\begin{array}{l}\text { Door to room is open } 10 \mathrm{~cm} \text {. Window } \\
\text { in room is open fully. }\end{array}$} \\
\hline D1 & \multirow{2}{*}{$1 / 4$} & $1 / 2$ & $1 / 8$ & \multicolumn{3}{|c|}{$\begin{array}{l}\text { Restart after moving generator to } \\
\text { location outside where CO does not } \\
\text { enter home; generator does not shut } \\
\text { off until the tank is empty. }\end{array}$} & \multicolumn{2}{|c|}{$\begin{array}{l}\text { The door between kitchen and outside } \\
\text { is open } 10 \mathrm{~cm} \text {. }\end{array}$} \\
\hline D2 & & $1 / 2$ & $1 / 8$ & \multicolumn{3}{|c|}{$\begin{array}{l}\text { Restart after moving generator to a } \\
\text { location outside of kitchen where } \\
\text { CO enters home; generator does not } \\
\text { shutoff until the tank is empty. }\end{array}$} & \multicolumn{2}{|c|}{$\begin{array}{l}\text { The door between outside and kitchen } \\
\text { is open } 10 \mathrm{~cm} \text {. }\end{array}$} \\
\hline
\end{tabular}


Table 2.b.i. Scenarios for Houses with no Basement, Garage, or Crawlspace with Generator Initially Operated in a First Floor Room that has a Door that Isolates It, with Generator Exhaust Plume Staying in Room [Scenario weight total to 3/4]

\begin{tabular}{|c|c|c|c|c|c|c|c|c|}
\hline \multicolumn{3}{|c|}{ Structure Type: } & \multicolumn{3}{|r|}{$\begin{array}{l}\text { Garage: } \\
\text { No }\end{array}$} & & Basement: No & $\begin{array}{l}\text { Crawlspace: } \\
\text { No }\end{array}$ \\
\hline \multicolumn{3}{|c|}{ Initial Location: } & \multicolumn{3}{|c|}{$\begin{array}{l}\text { Other 1st floor room with door that } \\
\text { isolates this room }\end{array}$} & \multicolumn{3}{|c|}{$\begin{array}{c}\text { Weight for Home Type: (\# deaths allocated to this } \\
\text { home *\% this location) }\end{array}$} \\
\hline \multicolumn{3}{|c|}{ Initial Conditions: } & \multicolumn{6}{|c|}{ Window in room is open $5 \mathrm{~cm}$. Door to room is open $10 \mathrm{~cm}$. } \\
\hline \multicolumn{9}{|c|}{ Scenarios } \\
\hline Scenario & $\begin{array}{c}\text { Scenario } \\
\text { Weight }\end{array}$ & $\begin{array}{c}\text { Sub-Scenario } \\
\text { Weight }\end{array}$ & Weight & Resp & utoff & & Changes from & ditions \\
\hline E & $3 / 12$ & 1 & $1 / 4$ & No $\mathrm{r}$ & & & N/A & \\
\hline $\mathrm{F} 1$ & \multirow{2}{*}{$3 / 12$} & $1 / 2$ & $1 / 8$ & \multicolumn{3}{|c|}{ Restart in room } & \multicolumn{2}{|l|}{ None. } \\
\hline F2 & & $1 / 2$ & $1 / 8$ & \multicolumn{3}{|c|}{ Restart in room } & \multicolumn{2}{|c|}{ Window in room is open fully. } \\
\hline G1 & \multirow{2}{*}{$3 / 12$} & $1 / 2$ & $1 / 8$ & \multicolumn{3}{|c|}{$\begin{array}{l}\text { Restart after moving generator to } \\
\text { location outside where CO does not } \\
\text { enter home; generator does not } \\
\text { shutoff until the tank is empty. }\end{array}$} & \multicolumn{2}{|c|}{$\begin{array}{l}\text { The door between kitchen and outside } \\
\text { is open } 10 \mathrm{~cm} \text {. Window in room is } \\
\text { closed. }\end{array}$} \\
\hline G2 & & $1 / 2$ & $1 / 8$ & \multicolumn{3}{|c|}{$\begin{array}{l}\text { Restart after moving generator to } \\
\text { location outside of kitchen where } \\
\text { CO enters home; generator does not } \\
\text { shutoff until the tank is empty. }\end{array}$} & \multicolumn{2}{|c|}{$\begin{array}{l}\text { The door between kitchen and outside } \\
\text { is open } 10 \mathrm{~cm} \text {. Window in room is } \\
\text { closed. }\end{array}$} \\
\hline
\end{tabular}


Table 2.b.ii. Scenarios for Houses with no Basement, Garage, or Crawlspace with Generator Initially Operated in a First Floor Room that has a Door that Isolates It with Generator Exhaust Oriented Out Door [Scenario weights equal to 1/4]

\begin{tabular}{|c|c|c|c|c|c|c|c|c|}
\hline \multicolumn{3}{|c|}{ Structure Type: } & \multicolumn{3}{|r|}{$\begin{array}{c}\text { Garage: } \\
\text { No }\end{array}$} & & Basement: No & $\begin{array}{l}\text { Crawlspace: } \\
\text { No }\end{array}$ \\
\hline \multicolumn{3}{|c|}{ Initial Location: } & \multicolumn{3}{|c|}{$\begin{array}{l}\text { Other 1st floor room with door that } \\
\text { isolates this room }\end{array}$} & \multicolumn{3}{|c|}{$\begin{array}{l}\text { Weight for Home Type: (\# deaths allocated to this } \\
\text { home * \% this location) }\end{array}$} \\
\hline \multicolumn{3}{|c|}{ Initial Conditions: } & \multicolumn{6}{|c|}{$\begin{array}{c}\text { Window in room is open } 5 \mathrm{~cm} \text {. Door to room is fully open. Exhaust oriented out of that } \\
\text { door. }\end{array}$} \\
\hline \multicolumn{9}{|c|}{ Scenarios } \\
\hline Scenario & $\begin{array}{c}\text { Scenario } \\
\text { Weight }\end{array}$ & $\begin{array}{l}\text { Sub-Scenario } \\
\text { Weight }\end{array}$ & Weight & \multicolumn{3}{|c|}{ Response to Shutoff } & \multicolumn{2}{|c|}{ Changes from Initial Conditions } \\
\hline $\mathrm{H}$ & $1 / 12$ & 1 & $1 / 12$ & \multicolumn{3}{|c|}{ No restart } & \multicolumn{2}{|l|}{ N/A } \\
\hline $\mathrm{I} 1$ & \multirow{2}{*}{$1 / 12$} & $1 / 2$ & $1 / 24$ & Rest & & & \multicolumn{2}{|l|}{ None. } \\
\hline $\mathrm{I} 2$ & & $1 / 2$ & $1 / 24$ & \multicolumn{3}{|c|}{ Restart in room } & \multicolumn{2}{|c|}{ Window in room is open fully. } \\
\hline $\mathrm{J} 1$ & \multirow{2}{*}{$1 / 12$} & $1 / 2$ & $1 / 24$ & \multicolumn{3}{|c|}{$\begin{array}{l}\text { Restart after moving generator to } \\
\text { location outside where CO does not } \\
\text { enter home; generator does not } \\
\text { shutoff until the tank is empty. }\end{array}$} & \multicolumn{2}{|c|}{$\begin{array}{l}\text { The door between kitchen and outside } \\
\text { is open } 10 \mathrm{~cm} \text {. Window in room is } \\
\text { closed. }\end{array}$} \\
\hline $\mathrm{J} 2$ & & $1 / 2$ & $1 / 24$ & \multicolumn{3}{|c|}{$\begin{array}{l}\text { Restart after moving generator to } \\
\text { location outside of kitchen where } \\
\text { CO enters home; generator does not } \\
\text { shutoff until the tank is empty. }\end{array}$} & \multicolumn{2}{|c|}{$\begin{array}{l}\text { The door between kitchen and outside } \\
\text { is open } 10 \mathrm{~cm} \text {. Window in room is } \\
\text { closed. }\end{array}$} \\
\hline
\end{tabular}

Table 2.c. Scenario for Houses with no Basement, Garage, or Crawlspace with Generator Initially Operated Outside

\begin{tabular}{|c|c|c|c|c|c|c|c|c|}
\hline \multicolumn{3}{|c|}{ Structure Type: } & \multicolumn{3}{|r|}{$\begin{array}{l}\text { Garage: } \\
\text { No }\end{array}$} & \multicolumn{2}{|r|}{ Basement: No } & $\begin{array}{l}\text { Crawlspace: } \\
\text { No }\end{array}$ \\
\hline \multicolumn{3}{|c|}{ Initial Location: } & \multicolumn{3}{|c|}{ Outside } & \multicolumn{3}{|c|}{$\begin{array}{l}\text { Weight for Home Type: (\# deaths outside this } \\
\text { home type) }\end{array}$} \\
\hline \multicolumn{3}{|c|}{ Initial Conditions: } & \multicolumn{6}{|c|}{$\begin{array}{c}\text { Exterior door to kitchen is open } 10 \mathrm{~cm} \text {. Start generator in a location outside of kitchen } \\
\text { where CO enters home. }\end{array}$} \\
\hline \multicolumn{9}{|c|}{ Restart Scenarios } \\
\hline Scenario & $\begin{array}{c}\text { Scenario } \\
\text { Weight }\end{array}$ & $\begin{array}{l}\text { Sub-Scenario } \\
\text { Weight }\end{array}$ & Weight & \multicolumn{3}{|c|}{ Response to Shutoff } & \multicolumn{2}{|c|}{ Changes from Initial Conditions } \\
\hline $\mathrm{K}$ & $\begin{array}{l}\text { Actual } \\
\text { Deaths } \\
\text { for } \\
\text { specific } \\
\text { house } \\
\text { model }\end{array}$ & - & $\begin{array}{l}\text { Actual } \\
\text { Deaths for } \\
\text { specific } \\
\text { house } \\
\text { model }\end{array}$ & \multicolumn{3}{|c|}{$\begin{array}{l}\text { Note: generator does not shutoff } \\
\text { until the tank is empty; therefore, } \\
\text { there are no restart scenarios. }\end{array}$} & \multicolumn{2}{|l|}{ N/A } \\
\hline
\end{tabular}


Table 3.a. Scenarios for Houses with Crawlspace but no Basement or Garage, with Generator Initially Operated in the Kitchen

\begin{tabular}{|c|c|c|c|c|c|c|c|c|}
\hline \multicolumn{3}{|c|}{ Structure Type: } & \multicolumn{3}{|r|}{$\begin{array}{l}\text { Jarage: } \\
\text { No }\end{array}$} & & Basement: No & $\begin{array}{c}\text { Crawlspace: } \\
\text { Yes } \\
\end{array}$ \\
\hline \multicolumn{3}{|c|}{ Initial Location: } & \multicolumn{3}{|c|}{ Kitchen (Living Space) } & \multicolumn{3}{|c|}{$\begin{array}{l}\text { Weight for Home Type: (\# deaths allocated to this } \\
\text { home } * \% \text { this location) }\end{array}$} \\
\hline \multicolumn{3}{|c|}{ Initial Conditions: } & \multicolumn{6}{|c|}{ Kitchen window is closed } \\
\hline \multicolumn{9}{|c|}{ Restart Scenarios } \\
\hline Scenario & $\begin{array}{l}\text { Scenario } \\
\text { Weight }\end{array}$ & $\begin{array}{l}\text { Sub-Scenario } \\
\text { Weight }\end{array}$ & Weight & & Ise to Shut & & Changes frc & Conditions \\
\hline A & $1 / 4$ & 1 & $1 / 4$ & No & & & N/A & \\
\hline B1 & \multirow{2}{*}{$1 / 4$} & $1 / 2$ & $1 / 8$ & \multicolumn{3}{|c|}{ Restart in kitchen. } & \multicolumn{2}{|l|}{ None. } \\
\hline B2 & & $1 / 2$ & $1 / 8$ & \multicolumn{3}{|c|}{ Restart in kitchen. } & \multicolumn{2}{|c|}{ Kitchen window is open fully. } \\
\hline C1 & \multirow{2}{*}{$1 / 4$} & $1 / 2$ & $1 / 8$ & \multicolumn{3}{|c|}{$\begin{array}{l}\text { Restart in center of other } 1 \text { st floor } \\
\text { room that has a door that isolates it. }\end{array}$} & \multicolumn{2}{|c|}{$\begin{array}{l}\text { Door to room is open } 10 \mathrm{~cm} \text {. Window } \\
\text { in room is open } 5 \mathrm{~cm} \text {. }\end{array}$} \\
\hline C2 & & $1 / 2$ & $1 / 8$ & \multicolumn{3}{|c|}{$\begin{array}{l}\text { Restart in center of other } 1 \text { st floor } \\
\text { room that has a door that isolates it. }\end{array}$} & \multicolumn{2}{|c|}{$\begin{array}{l}\text { Door to room is open } 10 \mathrm{~cm} \text {. Window } \\
\text { in room is open fully. }\end{array}$} \\
\hline D1 & \multirow{2}{*}{$1 / 4$} & $1 / 2$ & $1 / 8$ & \multicolumn{3}{|c|}{$\begin{array}{l}\text { Restart after moving generator to } \\
\text { location outside where CO does not } \\
\text { enter home; generator does not shut } \\
\text { off until the tank is empty. }\end{array}$} & \multicolumn{2}{|c|}{$\begin{array}{l}\text { The door between kitchen and outside } \\
\text { is open } 10 \mathrm{~cm} \text {. }\end{array}$} \\
\hline D2 & & $1 / 2$ & $1 / 8$ & \multicolumn{3}{|c|}{$\begin{array}{l}\text { Restart after moving generator to a } \\
\text { location outside of kitchen where } \\
\text { CO enters home; generator does not } \\
\text { shutoff until the tank is empty. }\end{array}$} & \multicolumn{2}{|c|}{$\begin{array}{l}\text { The door between outside and kitchen } \\
\text { is open } 10 \mathrm{~cm} \text {. }\end{array}$} \\
\hline
\end{tabular}


Table 3.b.i. Scenarios for Houses with Crawlspace but no Basement or Garage, with Generator Initially Operated in a First Floor Room with a Door that Isolated it with Generator Exhaust Plume Staying in Room [Scenario weight total to 3/4]

\begin{tabular}{|c|c|c|c|c|c|c|c|c|}
\hline \multicolumn{3}{|c|}{ Structure Type: } & \multicolumn{3}{|c|}{\begin{tabular}{c|c} 
House & $\begin{array}{c}\text { Garage } \\
\text { No }\end{array}$ \\
\end{tabular}} & & Basement: No & $\begin{array}{c}\text { Crawlspace: } \\
\text { Yes }\end{array}$ \\
\hline \multicolumn{3}{|c|}{ Initial Location: } & \multicolumn{3}{|c|}{$\begin{array}{l}\text { Other 1st floor room with door that } \\
\text { isolates this room }\end{array}$} & \multicolumn{3}{|c|}{$\begin{array}{c}\text { Weight for Home Type: (\# deaths allocated to this } \\
\text { home * \% this location) }\end{array}$} \\
\hline \multicolumn{3}{|c|}{ Initial Conditions: } & \multicolumn{6}{|c|}{ Window in room is open $5 \mathrm{~cm}$. Door to room is open $10 \mathrm{~cm}$. } \\
\hline \multicolumn{9}{|c|}{ Restart Scenarios } \\
\hline Scenario & $\begin{array}{c}\text { Scenario } \\
\text { Weight }\end{array}$ & $\begin{array}{l}\text { Sub-Scenario } \\
\text { Weight }\end{array}$ & Weight & & se to Shut & & Changes frc & Conditions \\
\hline E & $3 / 16$ & 1 & $3 / 16$ & No $\mathrm{r}$ & & & N/A & \\
\hline $\mathrm{F} 1$ & \multirow{2}{*}{$3 / 16$} & $1 / 2$ & $3 / 32$ & \multicolumn{3}{|c|}{ Restart in room. } & \multicolumn{2}{|l|}{ None. } \\
\hline F2 & & $1 / 2$ & $3 / 32$ & \multicolumn{3}{|c|}{ Restart in room. } & \multicolumn{2}{|c|}{ Window in room is open fully. } \\
\hline G & $3 / 16$ & 1 & $3 / 16$ & \multicolumn{3}{|c|}{ Restart in crawlspace } & \multicolumn{2}{|c|}{$\begin{array}{l}\text { Door to room is open fully. Window } \\
\text { in room is closed. }\end{array}$} \\
\hline H1 & \multirow{2}{*}{$3 / 16$} & $1 / 2$ & $3 / 32$ & \multicolumn{3}{|c|}{$\begin{array}{l}\text { Restart after moving generator to } \\
\text { location outside where CO does not } \\
\text { enter home; generator does not shut } \\
\text { off until the tank is empty. }\end{array}$} & \multicolumn{2}{|c|}{$\begin{array}{l}\text { The door between kitchen and outside } \\
\text { is open } 10 \mathrm{~cm} \text {. Window in room is } \\
\text { closed. }\end{array}$} \\
\hline $\mathrm{H} 2$ & & $1 / 2$ & $3 / 32$ & \multicolumn{3}{|c|}{$\begin{array}{l}\text { Restart after moving generator to a } \\
\text { location outside of kitchen where } \\
\text { CO enters home; generator does not } \\
\text { shutoff until the tank is empty. }\end{array}$} & \multicolumn{2}{|c|}{$\begin{array}{l}\text { The door between kitchen and outside } \\
\text { is open } 10 \mathrm{~cm} \text {. Window in room is } \\
\text { closed. }\end{array}$} \\
\hline
\end{tabular}


Table 3.b.ii. Scenarios for Houses with Crawlspace but no Basement or Garage, with Generator Initially Operated in a First Floor Room with a Door that Isolated it with Generator Exhaust Oriented out of Door [Scenario weights equal to 1/4]

\begin{tabular}{|c|c|c|c|c|c|c|c|c|}
\hline \multicolumn{3}{|c|}{ Structure Type: } & \multicolumn{3}{|c|}{\begin{tabular}{c|c} 
House & $\begin{array}{c}\text { Garage } \\
\text { No }\end{array}$ \\
\end{tabular}} & & Basement: No & $\begin{array}{c}\text { Crawlspace: } \\
\text { Yes }\end{array}$ \\
\hline \multicolumn{3}{|c|}{ Initial Location: } & \multicolumn{3}{|c|}{$\begin{array}{l}\text { Other 1st floor room with door that } \\
\text { isolates this room }\end{array}$} & \multicolumn{3}{|c|}{$\begin{array}{c}\text { Weight for Home Type: (\# deaths allocated to this } \\
\text { home * \% this location) }\end{array}$} \\
\hline \multicolumn{3}{|c|}{ Initial Conditions: } & \multicolumn{6}{|c|}{ Window in room is open $5 \mathrm{~cm}$. Door to room is fully open. Exhaust oriented out of door. } \\
\hline \multicolumn{9}{|c|}{ Restart Scenarios } \\
\hline Scenario & $\begin{array}{c}\text { Scenario } \\
\text { Weight }\end{array}$ & $\begin{array}{l}\text { Sub-Scenario } \\
\text { Weight }\end{array}$ & Weight & & se to Shut & & Changes frc & Conditions \\
\hline I & $1 / 16$ & 1 & $1 / 16$ & No 1 & & & N/A & \\
\hline $\mathrm{J} 1$ & \multirow{2}{*}{$1 / 16$} & $1 / 2$ & $1 / 32$ & \multicolumn{3}{|c|}{ Restart in room. } & \multicolumn{2}{|l|}{ None. } \\
\hline $\mathrm{J} 2$ & & $1 / 2$ & $1 / 32$ & \multicolumn{3}{|c|}{ Restart in room. } & \multicolumn{2}{|c|}{ Window in room is open fully. } \\
\hline K & $1 / 16$ & 1 & $1 / 16$ & \multicolumn{3}{|c|}{ Restart in crawlspace } & \multicolumn{2}{|c|}{$\begin{array}{l}\text { Door to room is open fully. Window } \\
\text { in room is closed. }\end{array}$} \\
\hline L1 & \multirow{2}{*}{$1 / 16$} & $1 / 2$ & $1 / 32$ & \multicolumn{3}{|c|}{$\begin{array}{l}\text { Restart after moving generator to } \\
\text { location outside where CO does not } \\
\text { enter home; generator does not shut } \\
\text { off until the tank is empty. }\end{array}$} & \multicolumn{2}{|c|}{$\begin{array}{l}\text { The door between kitchen and outside } \\
\text { is open } 10 \mathrm{~cm} \text {. Window in room is } \\
\text { closed. }\end{array}$} \\
\hline L2 & & $1 / 2$ & $1 / 32$ & \multicolumn{3}{|c|}{$\begin{array}{l}\text { Restart after moving generator to a } \\
\text { location outside of kitchen where } \\
\text { CO enters home; generator does not } \\
\text { shutoff until the tank is empty. }\end{array}$} & \multicolumn{2}{|c|}{$\begin{array}{l}\text { The door between kitchen and outside } \\
\text { is open } 10 \mathrm{~cm} \text {. Window in room is } \\
\text { closed. }\end{array}$} \\
\hline
\end{tabular}


Table 3.c. Scenarios for Houses with Crawlspace but no Basement or Garage, with Generator Initially Operated in the Crawlspace

\begin{tabular}{|c|c|c|c|c|c|c|c|c|}
\hline \multicolumn{3}{|c|}{ Structure Type: } & \multicolumn{3}{|c|}{ House } & \multicolumn{2}{|r|}{ Basement: No } & $\begin{array}{l}\text { Crawlspace: } \\
\text { Yes }\end{array}$ \\
\hline \multicolumn{3}{|c|}{ Initial Location: } & \multicolumn{3}{|c|}{$\begin{array}{l}\text { Other 1st floor room with door that } \\
\text { isolates this room }\end{array}$} & \multicolumn{3}{|c|}{$\begin{array}{l}\text { Weight for Home Type: (\# deaths allocated to this } \\
\text { home *\% this location) }\end{array}$} \\
\hline \multicolumn{3}{|c|}{ Initial Conditions: } & \multicolumn{6}{|c|}{$\begin{array}{l}\text { Generator is in crawlspace. No added ventilation. Door between kitchen and outside is open } \\
\qquad 10 \mathrm{~cm} \text {. }\end{array}$} \\
\hline \multicolumn{9}{|c|}{ Restart Scenarios } \\
\hline Scenario & $\begin{array}{c}\text { Scenario } \\
\text { Weight }\end{array}$ & $\begin{array}{l}\text { Sub-Scenario } \\
\text { Weight }\end{array}$ & Weight & & ise to Shut & & Changes fr & Conditions \\
\hline M & $1 / 3$ & 1 & $1 / 3$ & No & & & N/A & \\
\hline $\mathrm{N}$ & $1 / 3$ & 1 & $1 / 3$ & Res & lspace & & None. & \\
\hline O1 & \multirow{2}{*}{$1 / 3$} & $1 / 2$ & $1 / 6$ & $\begin{array}{l}\text { Res } \\
\text { loca } \\
\text { ente } \\
\text { off }\end{array}$ & $\begin{array}{l}\text { oving gen } \\
\text { e where C } \\
\text { nerator do } \\
\mathrm{k} \text { is empt }\end{array}$ & $\begin{array}{l}\text { dotor to } \\
\text { does not } \\
\text { s not shut }\end{array}$ & \multicolumn{2}{|c|}{$\begin{array}{l}\text { The door between kitchen and outside } \\
\text { is open } 10 \mathrm{~cm} \text {. }\end{array}$} \\
\hline $\mathrm{O} 2$ & & $1 / 2$ & $1 / 6$ & \multicolumn{3}{|c|}{$\begin{array}{l}\text { Restart after moving generator to a } \\
\text { location outside of kitchen where } \\
\text { CO enters home; generator does not } \\
\text { shutoff until the tank is empty. }\end{array}$} & \multicolumn{2}{|c|}{$\begin{array}{l}\text { The door between kitchen and outside } \\
\text { is open } 10 \mathrm{~cm} \text {. }\end{array}$} \\
\hline
\end{tabular}

Table 3.d. Scenario for Houses with Crawlspace but no Basement or Garage, with Generator Initially Operated Outside

\begin{tabular}{|c|c|c|c|c|c|c|c|c|}
\hline \multicolumn{3}{|c|}{ Structure Type: } & \multicolumn{3}{|r|}{$\begin{array}{l}\text { Garage: } \\
\text { No }\end{array}$} & & Basement: No & $\begin{array}{c}\text { Crawlspace: } \\
\text { Yes }\end{array}$ \\
\hline \multicolumn{3}{|c|}{ Initial Location: } & \multicolumn{3}{|c|}{ Outside } & \multicolumn{3}{|c|}{$\begin{array}{l}\text { Weight for Home Type: (\# deaths outside this } \\
\text { home type) }\end{array}$} \\
\hline \multicolumn{3}{|c|}{ Initial Conditions: } & \multicolumn{6}{|c|}{$\begin{array}{c}\text { Exterior door to kitchen is open } 10 \mathrm{~cm} \text {. Start generator in a location outside of kitchen } \\
\text { where CO enters home. }\end{array}$} \\
\hline \multicolumn{9}{|c|}{ Restart Scenarios } \\
\hline Scenario & $\begin{array}{l}\text { Scenario } \\
\text { Weight }\end{array}$ & $\begin{array}{l}\text { Sub-Scenario } \\
\text { Weight }\end{array}$ & Weight & \multicolumn{3}{|c|}{ Response to Shutoff } & \multicolumn{2}{|c|}{ Changes from Initial Conditions } \\
\hline $\mathrm{P}$ & $\begin{array}{l}\text { Actual } \\
\text { Deaths } \\
\text { for } \\
\text { specific } \\
\text { house } \\
\text { model }\end{array}$ & - & $\begin{array}{l}\text { Actual } \\
\text { Deaths for } \\
\text { specific } \\
\text { house } \\
\text { model }\end{array}$ & \multicolumn{3}{|c|}{$\begin{array}{l}\text { Note: generator does not shutoff } \\
\text { until the tank is empty; therefore, } \\
\text { there are no restart scenarios. }\end{array}$} & \multicolumn{2}{|l|}{ N/A } \\
\hline
\end{tabular}


Table 4.a. Scenarios for Houses with Basement, but no Crawlspace or Garage, with Generator Initially Operated in Kitchen

\begin{tabular}{|c|c|c|c|c|c|c|c|c|}
\hline \multicolumn{3}{|c|}{ Structure Type: } & \multicolumn{3}{|r|}{$\begin{array}{l}\text { Garage: } \\
\text { No }\end{array}$} & \multicolumn{2}{|r|}{ Basement: Yes } & $\begin{array}{l}\text { Crawlspace: } \\
\text { No }\end{array}$ \\
\hline \multicolumn{3}{|c|}{ Initial Location: } & \multicolumn{3}{|c|}{ Kitchen (Living Space) } & \multicolumn{3}{|c|}{$\begin{array}{c}\text { Weight for Home Type: (\# deaths allocated to this } \\
\text { home * \% this location) }\end{array}$} \\
\hline \multicolumn{3}{|c|}{ Initial Conditions: } & \multicolumn{6}{|c|}{ Kitchen window is closed. } \\
\hline \multicolumn{9}{|c|}{ Restart Scenarios } \\
\hline Scenario & $\begin{array}{c}\text { Scenario } \\
\text { Weight }\end{array}$ & $\begin{array}{l}\text { Sub-Scenario } \\
\text { Weight }\end{array}$ & Weight & & se to Shut & & Changes fr & Conditions \\
\hline $\mathrm{A}$ & $1 / 4$ & 1 & $1 / 4$ & No $\mathrm{r}$ & & & N/A & \\
\hline B1 & \multirow{2}{*}{$1 / 4$} & $1 / 2$ & $1 / 8$ & \multicolumn{3}{|c|}{ Restart in kitchen. } & None. & \\
\hline B2 & & $1 / 2$ & $1 / 8$ & \multicolumn{3}{|c|}{ Restart in kitchen. } & \multicolumn{2}{|c|}{ Kitchen window is open fully. } \\
\hline $\mathrm{C}$ & $1 / 4$ & 1 & $1 / 4$ & \multicolumn{3}{|c|}{ Restart in basement. } & \multicolumn{2}{|c|}{$\begin{array}{l}\text { Basement stairway door is open } 10 \\
\mathrm{~cm} \text {. Basement window is open fully. }\end{array}$} \\
\hline D1 & \multirow{2}{*}{$1 / 4$} & $1 / 2$ & $1 / 8$ & \multicolumn{3}{|c|}{$\begin{array}{l}\text { Restart after moving generator to } \\
\text { location outside where CO does not } \\
\text { enter home; generator does not shut } \\
\text { off until the tank is empty. }\end{array}$} & \multicolumn{2}{|c|}{$\begin{array}{l}\text { The door between kitchen and outside } \\
\text { is open } 10 \mathrm{~cm} \text {. }\end{array}$} \\
\hline D2 & & $1 / 2$ & $1 / 8$ & \multicolumn{3}{|c|}{$\begin{array}{l}\text { Restart after moving generator to a } \\
\text { location outside of kitchen where } \\
\text { CO enters home; generator does not } \\
\text { shutoff until the tank is empty. }\end{array}$} & \multicolumn{2}{|c|}{$\begin{array}{l}\text { The door between kitchen and outside } \\
\text { is open } 10 \mathrm{~cm} \text {. }\end{array}$} \\
\hline
\end{tabular}


Table 4.b. Scenarios for Houses with Basement, but no Crawlspace or Garage, with Generator Initially Operated in Basement

\begin{tabular}{|c|c|c|c|c|c|c|c|c|}
\hline \multicolumn{3}{|c|}{ Structure Type: } & \multicolumn{3}{|r|}{$\begin{array}{l}\text { Garage: } \\
\text { No }\end{array}$} & \multicolumn{2}{|r|}{ Basement: Yes } & $\begin{array}{l}\text { Crawlspace: } \\
\text { No }\end{array}$ \\
\hline \multicolumn{3}{|c|}{ Initial Location: } & \multicolumn{3}{|c|}{ Basement } & \multicolumn{3}{|c|}{$\begin{array}{l}\text { Weight for Home Type: (\# deaths allocated to this } \\
\text { home *\% this location) }\end{array}$} \\
\hline \multicolumn{3}{|c|}{ Initial Conditions: } & \multicolumn{6}{|c|}{ Basement stairway door is open $10 \mathrm{~cm}$. Window in basement is closed. } \\
\hline \multicolumn{9}{|c|}{ Restart Scenarios } \\
\hline Scenario & $\begin{array}{c}\text { Scenario } \\
\text { Weight }\end{array}$ & $\begin{array}{l}\text { Sub-Scenario } \\
\text { Weight }\end{array}$ & Weight & \multicolumn{3}{|c|}{ Response to Shutoff } & \multicolumn{2}{|c|}{ Changes from Initial Conditions } \\
\hline E & $1 / 3$ & 1 & $1 / 3$ & \multicolumn{3}{|c|}{ No restart } & \multicolumn{2}{|l|}{ N/A } \\
\hline F1 & \multirow{2}{*}{$1 / 3$} & $1 / 2$ & $1 / 6$ & \multicolumn{3}{|c|}{ Restart in basement. } & \multicolumn{2}{|l|}{ None. } \\
\hline F2 & & $1 / 2$ & $1 / 6$ & \multicolumn{3}{|c|}{ Restart in basement. } & \multicolumn{2}{|c|}{ Window in basement open fully. } \\
\hline G1 & \multirow{2}{*}{$1 / 3$} & $1 / 2$ & $1 / 6$ & \multicolumn{3}{|c|}{$\begin{array}{l}\text { Restart after moving generator to } \\
\text { location outside where CO does not } \\
\text { enter home; generator does not shut } \\
\text { off until the tank is empty. }\end{array}$} & \multicolumn{2}{|c|}{$\begin{array}{l}\text { The door between kitchen and outside } \\
\text { is open } 10 \mathrm{~cm} \text {. }\end{array}$} \\
\hline G2 & & $1 / 2$ & $1 / 6$ & \multicolumn{3}{|c|}{$\begin{array}{l}\text { Restart after moving generator to a } \\
\text { location outside of kitchen where } \\
\text { CO enters home; generator does not } \\
\text { shutoff until the tank is empty. }\end{array}$} & \multicolumn{2}{|c|}{$\begin{array}{l}\text { The door between kitchen and outside } \\
\text { is open } 10 \mathrm{~cm} \text {. }\end{array}$} \\
\hline
\end{tabular}

Table 4.c. Scenario for Houses with Basement, but no Crawlspace or Garage, with Generator Initially Operated Outside

\begin{tabular}{|c|c|c|c|c|c|c|c|c|}
\hline \multicolumn{3}{|c|}{ Structure Type: } & \multicolumn{3}{|r|}{$\begin{array}{l}\text { Garage: } \\
\text { No }\end{array}$} & \multicolumn{2}{|r|}{ Basement: Yes } & $\begin{array}{l}\text { Crawlspace: } \\
\text { No }\end{array}$ \\
\hline \multicolumn{3}{|c|}{ Initial Location: } & \multicolumn{3}{|c|}{ Outside } & \multicolumn{3}{|c|}{$\begin{array}{l}\text { Weight for Home Type: (\# deaths outside this } \\
\text { home type) }\end{array}$} \\
\hline \multicolumn{3}{|c|}{ Initial Conditions: } & \multicolumn{6}{|c|}{$\begin{array}{c}\text { Exterior door to kitchen is open } 10 \mathrm{~cm} \text {. Start generator in a location outside of kitchen } \\
\text { where CO enters home. }\end{array}$} \\
\hline \multicolumn{9}{|c|}{ Restart Scenarios } \\
\hline Scenario & $\begin{array}{c}\text { Scenario } \\
\text { Weight }\end{array}$ & $\begin{array}{l}\text { Sub-Scenario } \\
\text { Weight }\end{array}$ & Weight & \multicolumn{3}{|c|}{ Response to Shutoff } & \multicolumn{2}{|c|}{ Changes from Initial Conditions } \\
\hline $\mathrm{H}$ & $\begin{array}{l}\text { Actual } \\
\text { Deaths } \\
\text { for } \\
\text { specific } \\
\text { house } \\
\text { model }\end{array}$ & - & $\begin{array}{l}\text { Actual } \\
\text { Deaths for } \\
\text { specific } \\
\text { house } \\
\text { model }\end{array}$ & \multicolumn{3}{|c|}{$\begin{array}{l}\text { Note: generator does not shutoff } \\
\text { until the tank is empty; therefore, } \\
\text { there are no restart scenarios. }\end{array}$} & \multicolumn{2}{|l|}{ N/A } \\
\hline
\end{tabular}


Table 5.a. Scenarios for Houses with Garage but no Basement or Crawlspace, with Generator Initially Operated in the Kitchen

\begin{tabular}{|c|c|c|c|c|c|c|c|c|}
\hline \multicolumn{3}{|c|}{ Structure Type: } & \multicolumn{3}{|r|}{ arage: } & \multicolumn{2}{|r|}{ Basement: No } & $\begin{array}{l}\text { Crawlspace: } \\
\text { No }\end{array}$ \\
\hline \multicolumn{3}{|c|}{ Initial Location: } & \multicolumn{3}{|c|}{ Kitchen (Living Space) } & \multicolumn{3}{|c|}{$\begin{array}{c}\text { Weight for Home Type: (\# deaths allocated to this } \\
\text { home *\% this location) }\end{array}$} \\
\hline \multicolumn{3}{|c|}{ Initial Conditions: } & \multicolumn{6}{|c|}{ Kitchen window is closed. } \\
\hline \multicolumn{9}{|c|}{ Restart Scenarios } \\
\hline Scenario & $\begin{array}{l}\text { Scenario } \\
\text { Weight }\end{array}$ & $\begin{array}{l}\text { Sub-Scenario } \\
\text { Weight }\end{array}$ & Weight & & se to Shut & & Changes fr & Conditions \\
\hline $\mathrm{A}$ & $1 / 4$ & 1 & $1 / 4$ & No $\mathrm{r}$ & & \multicolumn{2}{|l|}{ N/A } \\
\hline B1 & \multirow{2}{*}{$1 / 4$} & $1 / 2$ & $1 / 8$ & Rest & & & None. & \\
\hline B2 & & $1 / 2$ & $1 / 8$ & \multicolumn{3}{|c|}{ Restart in kitchen. } & \\
\hline C1 & \multirow{4}{*}{$1 / 4$} & $\begin{array}{l}3 / 4 * 1 / 2 \\
=3 / 8\end{array}$ & $3 / 32$ & \multicolumn{3}{|c|}{$\begin{array}{l}\text { Move and restart in garage. } \\
\text { Exhaust facing away from door. }\end{array}$} & \multicolumn{2}{|c|}{$\begin{array}{l}\text { Bay door closed. Door to house } \\
\text { interior is open } 10 \mathrm{~cm} \text {. }\end{array}$} \\
\hline C2 & & $\begin{array}{l}1 / 4 * 1 / 2 \\
=1 / 8\end{array}$ & $1 / 32$ & \multicolumn{3}{|c|}{$\begin{array}{l}\text { Move and restart in garage. } \\
\text { Exhaust facing toward door. }\end{array}$} & \multicolumn{2}{|c|}{$\begin{array}{l}\text { interior is open } 10 \mathrm{~cm} \text {. } \\
\text { Bay door is open fully. Door to house } \\
\text { interior is open } 10 \mathrm{~cm} \text {. }\end{array}$} \\
\hline C3 & & $\begin{array}{l}3 / 4 * 1 / 2 \\
=3 / 8\end{array}$ & $3 / 32$ & \multicolumn{3}{|c|}{$\begin{array}{l}\text { Move and restart in garage. } \\
\text { Exhaust facing away from door. }\end{array}$} & \multicolumn{2}{|c|}{$\begin{array}{l}\text { interior is open } 10 \mathrm{~cm} \text {. } \\
\text { Bay door closed. Door to house } \\
\text { interior is open } 10 \mathrm{~cm} .\end{array}$} \\
\hline C4 & & $\begin{array}{l}1 / 4 * 1 / 2 \\
=1 / 8\end{array}$ & $1 / 32$ & \multicolumn{3}{|c|}{$\begin{array}{l}\text { Move and restart in garage. } \\
\text { Exhaust facing toward door. }\end{array}$} & \multicolumn{2}{|c|}{$\begin{array}{l}\text { Bay door is open fully. Door to house } \\
\text { interior is open } 10 \mathrm{~cm} \text {. }\end{array}$} \\
\hline D1 & \multirow{2}{*}{$1 / 4$} & $1 / 2$ & $1 / 8$ & \multicolumn{3}{|c|}{$\begin{array}{l}\text { Restart after moving generator to } \\
\text { location outside where CO does not } \\
\text { enter home; generator does not shut } \\
\text { off until the tank is empty. }\end{array}$} & \multicolumn{2}{|c|}{$\begin{array}{l}\text { The door between kitchen and outside } \\
\text { is open } 10 \mathrm{~cm} \text {. }\end{array}$} \\
\hline D2 & & $1 / 2$ & $1 / 8$ & \multicolumn{3}{|c|}{$\begin{array}{l}\text { Restart after moving generator to a } \\
\text { location outside of kitchen where } \\
\text { CO enters home; generator does not } \\
\text { shutoff until the tank is empty. }\end{array}$} & \multicolumn{2}{|c|}{$\begin{array}{l}\text { The door between kitchen and outside } \\
\text { is open } 10 \mathrm{~cm} \text {. }\end{array}$} \\
\hline
\end{tabular}


Table 5.b.i. Scenarios for Houses with Garage but no Basement or Crawlspace, with Generator Initially Operated in a First Floor Room that has a Door that Isolates it with Generator Exhaust Plume Staying in Room [Scenario weight total to 3/4]

\begin{tabular}{|c|c|c|c|c|c|c|c|c|}
\hline \multicolumn{3}{|c|}{ Structure Type: } & \multicolumn{3}{|c|}{ House } & & Basement: No & $\begin{array}{c}\text { Crawlspace: } \\
\text { No }\end{array}$ \\
\hline \multicolumn{3}{|c|}{ Initial Location: } & \multicolumn{3}{|c|}{$\begin{array}{l}\text { Other 1st floor room with door that } \\
\text { isolates this room }\end{array}$} & \multicolumn{3}{|c|}{$\begin{array}{c}\text { Weight for Home Type: (\# deaths allocated to this } \\
\text { home *\% this location) }\end{array}$} \\
\hline \multicolumn{3}{|c|}{ Initial Conditions: } & \multicolumn{6}{|c|}{ Window in room is open $5 \mathrm{~cm}$. Door to room is open $10 \mathrm{~cm}$. } \\
\hline \multicolumn{9}{|c|}{ Restart Scenarios } \\
\hline Scenario & $\begin{array}{l}\text { Scenario } \\
\text { Weight }\end{array}$ & $\begin{array}{l}\text { Sub-Scenario } \\
\text { Weight }\end{array}$ & Weight & & se to Shut & & Changes fr & Conditions \\
\hline E & $3 / 16$ & 1 & $3 / 16$ & & \multicolumn{2}{|l|}{ N/A } \\
\hline F1 & \multirow{2}{*}{$3 / 16$} & $1 / 2$ & $3 / 32$ & \multicolumn{3}{|c|}{ Restart in room. } & \multicolumn{2}{|l|}{ None. } \\
\hline F2 & & $1 / 2$ & $3 / 32$ & \multicolumn{3}{|c|}{ Restart in room. } & \multicolumn{2}{|c|}{ Window in room is open fully. } \\
\hline G1 & \multirow{4}{*}{ 3/16 } & $\begin{array}{l}3 / 4 * 1 / 2 \\
=3 / 8\end{array}$ & 9/128 & \multicolumn{3}{|c|}{$\begin{array}{l}\text { Move and restart in garage. } \\
\text { Exhaust facing away from door. }\end{array}$} & \multicolumn{2}{|c|}{$\begin{array}{l}\text { Bay door is closed. Door to house } \\
\text { interior is open } 10 \mathrm{~cm} \text {. Door to first } \\
\text { floor room is open fully and room } \\
\text { window is closed. }\end{array}$} \\
\hline G2 & & $\begin{array}{c}1 / 4 * 1 / 2 \\
=1 / 8\end{array}$ & $3 / 128$ & \multicolumn{3}{|c|}{$\begin{array}{l}\text { Move and restart in garage. } \\
\text { Exhaust facing toward door. }\end{array}$} & \multicolumn{2}{|c|}{$\begin{array}{l}\text { Bay door is closed. Door to house } \\
\text { interior is open } 10 \mathrm{~cm} \text {. Door to first } \\
\text { floor room is open fully and room } \\
\text { window is closed. }\end{array}$} \\
\hline G3 & & $\begin{array}{l}3 / 4 * 1 / 2 \\
=3 / 8\end{array}$ & 9/128 & \multicolumn{3}{|c|}{$\begin{array}{l}\text { Move and restart in garage. } \\
\text { Exhaust facing away from door. }\end{array}$} & \multicolumn{2}{|c|}{$\begin{array}{l}\text { Bay door is open fully. Door to house } \\
\text { interior is open } 10 \mathrm{~cm} \text {. Door to first } \\
\text { floor room is open fully and room } \\
\text { window is closed. }\end{array}$} \\
\hline G4 & & $\begin{array}{c}1 / 4 * 1 / 2 \\
=1 / 8\end{array}$ & $3 / 128$ & \multicolumn{3}{|c|}{$\begin{array}{l}\text { Move and restart in garage. } \\
\text { Exhaust facing toward door. }\end{array}$} & \multicolumn{2}{|c|}{$\begin{array}{l}\text { Bay door is open fully. Door to house } \\
\text { interior is open } 10 \mathrm{~cm} \text {. Door to first } \\
\text { floor room is open fully and room } \\
\text { window is closed. }\end{array}$} \\
\hline H1 & \multirow{2}{*}{$3 / 16$} & $1 / 2$ & $3 / 32$ & \multicolumn{3}{|c|}{$\begin{array}{l}\text { Restart after moving generator to } \\
\text { location outside where CO does not } \\
\text { enter home; generator does not shut } \\
\text { off until the tank is empty. }\end{array}$} & \multicolumn{2}{|c|}{$\begin{array}{l}\text { The door between kitchen and outside } \\
\text { is open } 10 \mathrm{~cm} \text {. Door to first floor room } \\
\text { is open fully and room window is } \\
\text { closed. }\end{array}$} \\
\hline H2 & & $1 / 2$ & 3/32 & \multicolumn{3}{|c|}{$\begin{array}{l}\text { Restart after moving generator to a } \\
\text { location outside of kitchen where } \\
\text { CO enters home; generator does not } \\
\text { shutoff until the tank is empty. }\end{array}$} & \multicolumn{2}{|c|}{$\begin{array}{l}\text { The door between kitchen and outside } \\
\text { is open } 10 \mathrm{~cm} \text {. Door to first floor room } \\
\text { is open fully and room window is } \\
\text { closed. }\end{array}$} \\
\hline
\end{tabular}


Table 5.b.ii. Scenarios for Houses with Garage but no Basement or Crawlspace, with Generator Initially Operated in a First Floor Room that has a Door that Isolates it with Generator Exhaust Pointed out the Door [Scenario weights equal to 1/4]

\begin{tabular}{|c|c|c|c|c|c|c|c|c|}
\hline \multicolumn{3}{|c|}{ Structure Type: } & \multicolumn{3}{|c|}{\begin{tabular}{c|c} 
House & $\begin{array}{c}\text { Garage: } \\
\text { Yes }\end{array}$ \\
\end{tabular}} & & Basement: No & $\begin{array}{l}\text { Crawlspace: } \\
\text { No }\end{array}$ \\
\hline \multicolumn{3}{|c|}{ Initial Location: } & \multicolumn{3}{|c|}{$\begin{array}{l}\text { Other 1st floor room with door that } \\
\text { isolates this room }\end{array}$} & \multicolumn{3}{|c|}{$\begin{array}{l}\text { Weight for Home Type: (\# deaths allocated to this } \\
\text { home *\% this location) }\end{array}$} \\
\hline \multicolumn{3}{|c|}{ Initial Conditions: } & \multicolumn{6}{|c|}{$\begin{array}{c}\begin{array}{c}\text { Window in room is open } 5 \mathrm{~cm} \text {. Door to room is open } 10 \mathrm{~cm} \text {. Exhaust is pointed out the } \\
\text { door. }\end{array}\end{array}$} \\
\hline \multicolumn{9}{|c|}{ Restart Scenarios } \\
\hline Scenario & $\begin{array}{c}\text { Scenario } \\
\text { Weight }\end{array}$ & $\begin{array}{c}\text { Sub-Scenario } \\
\text { Weight }\end{array}$ & Weight & & ise to Shut & & Changes fr & Conditions \\
\hline I & $1 / 16$ & 1 & $1 / 16$ & \multicolumn{3}{|c|}{ No restart } & \multicolumn{2}{|l|}{ N/A } \\
\hline $\mathrm{J} 1$ & \multirow{2}{*}{$1 / 16$} & $1 / 2$ & $1 / 32$ & \multicolumn{3}{|c|}{ Restart in room. } & \multicolumn{2}{|l|}{ None. } \\
\hline $\mathrm{J} 2$ & & $1 / 2$ & $1 / 32$ & \multicolumn{3}{|c|}{ Restart in room. } & \multicolumn{2}{|c|}{ Window in room is open fully. } \\
\hline K1 & \multirow{4}{*}{$1 / 16$} & $\begin{array}{l}3 / 4 * 1 / 2 \\
=3 / 8\end{array}$ & $3 / 128$ & \multicolumn{3}{|c|}{$\begin{array}{l}\text { Restart in garage. Exhaust facing } \\
\text { away from door. }\end{array}$} & \multicolumn{2}{|c|}{$\begin{array}{l}\text { Bay door is closed. Door to house } \\
\text { interior is open } 10 \mathrm{~cm} \text {. Door to first } \\
\text { floor room is open fully and room } \\
\text { window is closed. }\end{array}$} \\
\hline K2 & & $\begin{array}{l}1 / 4 * 1 / 2 \\
=1 / 8\end{array}$ & $1 / 128$ & \multicolumn{3}{|c|}{$\begin{array}{l}\text { Restart in garage. Exhaust facing } \\
\text { toward door. }\end{array}$} & \multicolumn{2}{|c|}{$\begin{array}{l}\text { Bay door is closed. Door to house } \\
\text { interior is open } 10 \mathrm{~cm} \text {. Door to first } \\
\text { floor room is open fully and room } \\
\text { window is closed. }\end{array}$} \\
\hline K3 & & $\begin{array}{l}3 / 4 * 1 / 2 \\
=3 / 8\end{array}$ & $3 / 128$ & \multicolumn{3}{|c|}{$\begin{array}{l}\text { Restart in garage. Exhaust facing } \\
\text { away from door. }\end{array}$} & \multicolumn{2}{|c|}{$\begin{array}{l}\text { Bay door is open fully. Door to house } \\
\text { interior is open } 10 \mathrm{~cm} \text {. Door to first } \\
\text { floor room is open fully and room } \\
\text { window is closed }\end{array}$} \\
\hline K4 & & $\begin{array}{l}1 / 4 * 1 / 2 \\
=1 / 8\end{array}$ & $1 / 128$ & \multicolumn{3}{|c|}{$\begin{array}{l}\text { Restart in garage. Exhaust facing } \\
\text { toward door. }\end{array}$} & \multicolumn{2}{|c|}{$\begin{array}{l}\text { Bay door is open fully. Door to house } \\
\text { interior is open } 10 \mathrm{~cm} \text {. Door to first } \\
\text { floor room is open fully and room } \\
\text { window is closed. }\end{array}$} \\
\hline L1 & \multirow{2}{*}{$1 / 16$} & $1 / 2$ & $1 / 32$ & \multicolumn{3}{|c|}{$\begin{array}{l}\text { Restart after moving generator to } \\
\text { location outside where CO does not } \\
\text { enter home; generator does not shut } \\
\text { off until the tank is empty. }\end{array}$} & \multicolumn{2}{|c|}{$\begin{array}{l}\text { The door between kitchen and outside } \\
\text { is open } 10 \mathrm{~cm} \text {. Door to first floor room } \\
\text { is open fully and room window is } \\
\text { closed. }\end{array}$} \\
\hline L2 & & $1 / 2$ & $1 / 32$ & \multicolumn{3}{|c|}{$\begin{array}{l}\text { Restart after moving generator to a } \\
\text { location outside of kitchen where } \\
\text { CO enters home; generator does not } \\
\text { shutoff until the tank is empty. }\end{array}$} & \multicolumn{2}{|c|}{$\begin{array}{l}\text { The door between kitchen and outside } \\
\text { is open } 10 \mathrm{~cm} \text {. Door to first floor room } \\
\text { is open fully and room window is } \\
\text { closed. }\end{array}$} \\
\hline
\end{tabular}


Table 5.c.i. Scenarios for Houses with Garage but no Basement or Crawlspace, with Generator Initially Operated in Garage with Generator Exhaust Facing Away from Door to House Interior [Scenario weight total to 3/4]

\begin{tabular}{|c|c|c|c|c|c|c|c|c|}
\hline \multicolumn{3}{|c|}{ Structure Type: } & & use & $\begin{array}{c}\text { Garage: } \\
\text { Yes }\end{array}$ & & Basement: No & $\begin{array}{c}\text { Crawlspace: } \\
\text { No }\end{array}$ \\
\hline \multicolumn{3}{|c|}{ Initial Location: } & \multicolumn{3}{|c|}{ Garage } & \multicolumn{3}{|c|}{$\begin{array}{l}\text { Weight for Home Type: (\# deaths allocated to this } \\
\text { home * \% this location) }\end{array}$} \\
\hline \multicolumn{3}{|c|}{ Initial Conditions: } & \multicolumn{6}{|c|}{$\begin{array}{l}\text { Door to house interior is open } 10 \mathrm{~cm} \text {. Bay door is closed. Generator is in center of garage. } \\
\text { Exhaust is facing away from door to house interior. }\end{array}$} \\
\hline \multicolumn{9}{|c|}{ Restart Scenarios } \\
\hline Scenario & $\begin{array}{l}\text { Scenario } \\
\text { Weight }\end{array}$ & $\begin{array}{l}\text { Sub-Scenario } \\
\text { Weight }\end{array}$ & Weight & \multicolumn{3}{|c|}{ Response to Shutoff } & \multicolumn{2}{|c|}{ Changes from Initial Conditions } \\
\hline $\mathrm{M}$ & $3 / 12$ & 1 & $3 / 12$ & \multicolumn{3}{|c|}{ No restart } & \multicolumn{2}{|l|}{ N/A } \\
\hline N1 & \multirow{2}{*}{$3 / 12$} & $1 / 2$ & $3 / 24$ & \multicolumn{3}{|c|}{ Restart in garage. } & \multicolumn{2}{|l|}{ None. } \\
\hline N2 & & $1 / 2$ & $3 / 24$ & \multicolumn{3}{|c|}{ Restart in garage. } & \multicolumn{2}{|c|}{ Bay door fully open. } \\
\hline $\mathrm{O} 1$ & \multirow{2}{*}{$3 / 12$} & $1 / 2$ & $3 / 24$ & \multicolumn{3}{|c|}{$\begin{array}{l}\text { Restart after moving generator to } \\
\text { location outside of garage where } \\
\text { CO does not enter home; generator } \\
\text { does not shutoff until the tank is } \\
\text { empty. }\end{array}$} & \multicolumn{2}{|c|}{$\begin{array}{l}\text { Occupant opens bay door to remove } \\
\text { generator and then closes it } 2 \text { minutes } \\
\text { later. }\end{array}$} \\
\hline $\mathrm{O} 2$ & & $1 / 2$ & $3 / 24$ & \multicolumn{3}{|c|}{$\begin{array}{l}\text { Restart after moving generator to a } \\
\text { location outside of kitchen where } \\
\text { CO enters home; generator does not } \\
\text { shutoff until the tank is empty. }\end{array}$} & \multicolumn{2}{|c|}{$\begin{array}{l}\text { Bay door is open fully and exhaust is } \\
\text { pointed into garage. }\end{array}$} \\
\hline
\end{tabular}


Table 5.c.ii. Scenarios for Houses with Garage but no Basement or Crawlspace, with Generator Initially Operated in Garage with Generator Exhaust Oriented Toward Door to House Interior [Scenario weight total to $1 / 4$ ]

\begin{tabular}{|c|c|c|c|c|c|c|c|c|}
\hline \multicolumn{3}{|c|}{ Structure Type: } & & use & $\begin{array}{c}\text { Garage: } \\
\text { Yes }\end{array}$ & & Basement: No & $\begin{array}{l}\text { Crawlspace: } \\
\text { No }\end{array}$ \\
\hline \multicolumn{3}{|c|}{ Initial Location: } & \multicolumn{3}{|c|}{ Basement } & \multicolumn{3}{|c|}{$\begin{array}{l}\text { Weight for Home Type: (\# deaths allocated to this } \\
\text { home *\% this location) }\end{array}$} \\
\hline \multicolumn{3}{|c|}{ Initial Conditions: } & \multicolumn{6}{|c|}{$\begin{array}{l}\text { Door to house interior is open } 10 \mathrm{~cm} \text {. Bay door is closed. Generator is in center of garage. } \\
\text { Exhaust is facing towards door to house interior. }\end{array}$} \\
\hline \multicolumn{9}{|c|}{ Restart Scenarios } \\
\hline Scenario & $\begin{array}{c}\text { Scenario } \\
\text { Weight }\end{array}$ & $\begin{array}{l}\text { Sub-Scenario } \\
\text { Weight }\end{array}$ & Weight & \multicolumn{3}{|c|}{ Response to Shutoff } & \multicolumn{2}{|c|}{ Changes from Initial Conditions } \\
\hline $\mathrm{P}$ & $1 / 12$ & 1 & $1 / 12$ & \multicolumn{3}{|c|}{ No restart } & \multicolumn{2}{|l|}{ N/A } \\
\hline Q1 & \multirow{2}{*}{$1 / 12$} & $1 / 2$ & $1 / 24$ & \multicolumn{3}{|c|}{ Restart in garage. } & \multicolumn{2}{|l|}{ None. } \\
\hline Q2 & & $1 / 2$ & $1 / 24$ & \multicolumn{3}{|c|}{ Restart in garage. } & \multicolumn{2}{|c|}{ Bay door fully open. } \\
\hline R1 & \multirow{2}{*}{$1 / 12$} & $1 / 2$ & $1 / 24$ & \multicolumn{3}{|c|}{$\begin{array}{l}\text { Restart after moving generator to } \\
\text { location outside of garage where } \\
\text { CO does not enter home; generator } \\
\text { does not shutoff until the tank is } \\
\text { empty. }\end{array}$} & \multicolumn{2}{|c|}{$\begin{array}{l}\text { Occupant opens bay door to remove } \\
\text { generator and then closes it } 2 \text { minutes } \\
\text { later. }\end{array}$} \\
\hline R2 & & $1 / 2$ & $1 / 24$ & \multicolumn{3}{|c|}{$\begin{array}{l}\text { Restart after moving generator to a } \\
\text { location outside of kitchen where } \\
\text { CO enters home; generator does not } \\
\text { shutoff until the tank is empty. }\end{array}$} & \multicolumn{2}{|c|}{$\begin{array}{l}\text { Bay door is open fully and exhaust is } \\
\text { pointed into garage. }\end{array}$} \\
\hline
\end{tabular}

Table 5.d. Scenario for Houses with Garage but no Basement or Crawlspace, with Generator Initially Operated Outside

\begin{tabular}{|c|c|c|c|c|c|c|c|c|}
\hline \multicolumn{3}{|c|}{ Structure Type: } & & ouse & $\begin{array}{c}\text { Garage: } \\
\text { Yes }\end{array}$ & & Basement: No & $\begin{array}{l}\text { Crawlspace: } \\
\text { No }\end{array}$ \\
\hline \multicolumn{3}{|c|}{ Initial Location: } & \multicolumn{3}{|c|}{ Outside } & \multicolumn{3}{|c|}{$\begin{array}{l}\text { Weight for Home Type: (\# deaths outside this } \\
\text { home type) }\end{array}$} \\
\hline \multicolumn{3}{|c|}{ Initial Conditions: } & \multicolumn{6}{|c|}{$\begin{array}{c}\text { Exterior door to kitchen is open } 10 \mathrm{~cm} \text {. Start generator in a location outside of kitchen } \\
\text { where CO enters home. }\end{array}$} \\
\hline \multicolumn{9}{|c|}{ Restart Scenarios } \\
\hline Scenario & $\begin{array}{l}\text { Scenario } \\
\text { Weight }\end{array}$ & $\begin{array}{l}\text { Sub-Scenario } \\
\text { Weight }\end{array}$ & Weight & \multicolumn{3}{|c|}{ Response to Shutoff } & \multicolumn{2}{|c|}{ Changes from Initial Conditions } \\
\hline S & $\begin{array}{l}\text { Actual } \\
\text { Deaths } \\
\text { for } \\
\text { specific } \\
\text { house } \\
\text { model }\end{array}$ & - & $\begin{array}{l}\text { Actual } \\
\text { Deaths for } \\
\text { specific } \\
\text { house } \\
\text { model }\end{array}$ & \multicolumn{3}{|c|}{$\begin{array}{l}\text { Note: generator does not shutoff } \\
\text { until the tank is empty; therefore, } \\
\text { there are no restart scenarios. }\end{array}$} & N/A & \\
\hline
\end{tabular}


Table 6.a. Scenario for Houses with Garage and Basement but no Crawlspace, with Generator Initially Operated in Kitchen

\begin{tabular}{|c|c|c|c|c|c|c|c|}
\hline \multicolumn{3}{|c|}{ Structure Type: } & \multicolumn{2}{|r|}{$\begin{array}{c}\text { Garage: } \\
\text { Yes }\end{array}$} & \multicolumn{2}{|r|}{ Basement: Yes } & $\begin{array}{l}\text { Crawlspace: } \\
\text { No }\end{array}$ \\
\hline \multicolumn{3}{|c|}{ Initial Location: } & \multicolumn{2}{|c|}{ Kitchen (Living Space) } & \multicolumn{3}{|c|}{$\begin{array}{c}\text { Weight for Home Type: (\# deaths allocated to this } \\
\text { home * \% this location) }\end{array}$} \\
\hline \multicolumn{3}{|c|}{ Initial Conditions: } & \multicolumn{5}{|c|}{ Kitchen window is closed. } \\
\hline \multicolumn{8}{|c|}{ Restart Scenarios } \\
\hline Scenario & $\begin{array}{c}\text { Scenario } \\
\text { Weight }\end{array}$ & $\begin{array}{l}\text { Sub-Scenario } \\
\text { Weight }\end{array}$ & Weight & \multicolumn{2}{|c|}{ Response to Shutoff } & \multicolumn{2}{|c|}{ Changes from Initial Conditions } \\
\hline $\mathrm{A}$ & $1 / 4$ & 1 & $1 / 4$ & \multicolumn{2}{|l|}{ No restart } & \multicolumn{2}{|l|}{ N/A } \\
\hline B1 & \multirow{2}{*}{$1 / 4$} & $1 / 2$ & $1 / 8$ & Restart in kitchen. & & \multicolumn{2}{|l|}{ None. } \\
\hline B2 & & $1 / 2$ & $1 / 8$ & \multicolumn{2}{|l|}{ Restart in kitchen. } & \multicolumn{2}{|c|}{ Kitchen window is open fully. } \\
\hline $\mathrm{C} 1$ & \multirow{4}{*}{$1 / 4$} & $\begin{array}{l}3 / 4 * 1 / 2 \\
=3 / 8\end{array}$ & $3 / 32$ & \multicolumn{2}{|c|}{$\begin{array}{l}\text { Restart in garage. Exhaust facing } \\
\text { away from door. }\end{array}$} & \multicolumn{2}{|c|}{$\begin{array}{l}\text { Bay door closed. Door to house } \\
\text { interior is open } 10 \mathrm{~cm} \text {. Kitchen } \\
\text { window is closed. }\end{array}$} \\
\hline $\mathrm{C} 2$ & & $\begin{array}{l}1 / 4 * 1 / 2 \\
=1 / 8\end{array}$ & $1 / 32$ & \multicolumn{2}{|c|}{$\begin{array}{l}\text { Restart in garage. Exhaust facing } \\
\text { toward door. }\end{array}$} & \multicolumn{2}{|c|}{$\begin{array}{l}\text { Bay door closed. Door to house } \\
\text { interior is open } 10 \mathrm{~cm} \text {. Kitchen } \\
\text { window is closed. }\end{array}$} \\
\hline C3 & & $\begin{array}{l}3 / 4 * 1 / 2 \\
=3 / 8\end{array}$ & $3 / 32$ & \multicolumn{2}{|c|}{$\begin{array}{l}\text { Restart in garage. Exhaust facing } \\
\text { away from door. }\end{array}$} & \multicolumn{2}{|c|}{$\begin{array}{l}\text { Bay door is fully open. Door to house } \\
\text { interior is open } 10 \mathrm{~cm} \text {. Kitchen } \\
\text { window is closed. }\end{array}$} \\
\hline $\mathrm{C} 4$ & & $\begin{array}{l}1 / 4 * 1 / 2 \\
=1 / 8\end{array}$ & $1 / 32$ & \multicolumn{2}{|c|}{$\begin{array}{l}\text { Restart in garage. Exhaust facing } \\
\text { toward door. }\end{array}$} & \multicolumn{2}{|c|}{$\begin{array}{l}\text { Bay door is fully open. Door to house } \\
\text { interior is open } 10 \mathrm{~cm} \text {. Kitchen } \\
\text { window is closed. }\end{array}$} \\
\hline D1 & \multirow{2}{*}{$1 / 4$} & $1 / 2$ & $1 / 8$ & \multicolumn{2}{|c|}{$\begin{array}{l}\text { Restart after moving generator to } \\
\text { location outside where CO does not } \\
\text { enter home; generator does not shut } \\
\text { off until the tank is embtv }\end{array}$} & \multicolumn{2}{|c|}{$\begin{array}{l}\text { The door between kitchen and outside } \\
\text { is open } 10 \mathrm{~cm} \text {. Kitchen window is } \\
\text { closed. }\end{array}$} \\
\hline D2 & & $1 / 2$ & $1 / 8$ & \multicolumn{2}{|c|}{$\begin{array}{l}\text { Restart after moving generator to a } \\
\text { location outside of kitchen where } \\
\text { CO enters home; generator does not } \\
\text { shutoff until the tank is empty. }\end{array}$} & \multicolumn{2}{|c|}{$\begin{array}{l}\text { The door between outside and kitchen } \\
\text { is open } 10 \mathrm{~cm} \text {. Kitchen window is } \\
\text { closed. }\end{array}$} \\
\hline
\end{tabular}


Table 6.b. Scenarios for Houses with Garage and Basement but no Crawlspace, with Generator Initially Operated in Basement

\begin{tabular}{|c|c|c|c|c|c|c|c|}
\hline \multicolumn{3}{|c|}{ Structure Type: } & \multicolumn{2}{|r|}{ Garage: } & \multicolumn{2}{|r|}{ Basement: Yes } & $\begin{array}{l}\text { Crawlspace: } \\
\text { No }\end{array}$ \\
\hline \multicolumn{3}{|c|}{ Initial Location: } & \multicolumn{2}{|r|}{ Basement } & \multicolumn{3}{|c|}{$\begin{array}{l}\text { Weight for Home Type: (\# deaths allocated to this } \\
\text { home *\% this location) }\end{array}$} \\
\hline \multicolumn{3}{|c|}{ Initial Conditions: } & \multicolumn{5}{|c|}{ Basement stairway door is open $10 \mathrm{~cm}$. Basement window is closed. } \\
\hline \multicolumn{8}{|c|}{ Restart Scenarios } \\
\hline Scenario & $\begin{array}{c}\text { Scenario } \\
\text { Weight }\end{array}$ & $\begin{array}{l}\text { Sub-Scenario } \\
\text { Weight }\end{array}$ & Weight & Response to Shut & & & Conditions \\
\hline E & $1 / 4$ & 1 & $1 / 4$ & No restart & & N/A & \\
\hline $\mathrm{F} 1$ & \multirow{2}{*}{$1 / 4$} & $1 / 2$ & $1 / 8$ & \multicolumn{2}{|l|}{ Restart in basement. } & \multicolumn{2}{|l|}{ None. } \\
\hline F2 & & $1 / 2$ & $1 / 8$ & \multicolumn{2}{|l|}{ Restart in basement. } & \multicolumn{2}{|c|}{ Basement window is open fully. } \\
\hline G1 & \multirow{4}{*}{$1 / 4$} & $\begin{array}{l}3 / 4 * 1 / 2 \\
=3 / 8\end{array}$ & 3/32 & \multicolumn{2}{|c|}{$\begin{array}{l}\text { Restart in garage. Exhaust facing } \\
\text { away from door. }\end{array}$} & \multicolumn{2}{|c|}{$\begin{array}{l}\text { Bay door closed. Door to house } \\
\text { interior is open } 10 \mathrm{~cm} \text {. Basement } \\
\text { window is closed. }\end{array}$} \\
\hline G2 & & $\begin{array}{l}1 / 4 * 1 / 2 \\
=1 / 8\end{array}$ & $1 / 32$ & \multicolumn{2}{|c|}{$\begin{array}{l}\text { Restart in garage. Exhaust facing } \\
\text { toward door. }\end{array}$} & \multicolumn{2}{|c|}{$\begin{array}{l}\text { Bay door closed. Door to house } \\
\text { interior is open } 10 \mathrm{~cm} \text {. Basement } \\
\text { window is closed. }\end{array}$} \\
\hline G3 & & $\begin{array}{l}3 / 4 * 1 / 2 \\
=3 / 8\end{array}$ & $3 / 32$ & \multicolumn{2}{|c|}{$\begin{array}{l}\text { Restart in garage. Exhaust facing } \\
\text { away from door. }\end{array}$} & \multicolumn{2}{|c|}{$\begin{array}{l}\text { Bay door is open fully. Door to house } \\
\text { interior is open } 10 \mathrm{~cm} \text {. Basement } \\
\text { window is closed. }\end{array}$} \\
\hline G4 & & $\begin{array}{l}1 / 4 * 1 / 2 \\
=1 / 8\end{array}$ & $1 / 32$ & \multicolumn{2}{|c|}{$\begin{array}{l}\text { Restart in garage. Exhaust facing } \\
\text { toward door. }\end{array}$} & \multicolumn{2}{|c|}{$\begin{array}{l}\text { Bay door is open fully. Door to house } \\
\text { interior is open } 10 \mathrm{~cm} \text {. Basement } \\
\text { window is closed. }\end{array}$} \\
\hline H1 & \multirow{2}{*}{$1 / 4$} & $1 / 2$ & $1 / 8$ & \multicolumn{2}{|c|}{$\begin{array}{l}\text { Restart after moving generator to } \\
\text { location outside where CO does not } \\
\text { enter home; generator does not shut } \\
\text { off until the tank is empty. }\end{array}$} & \multicolumn{2}{|c|}{$\begin{array}{l}\text { The door between outside and kitchen } \\
\text { is open } 10 \mathrm{~cm} \text {. }\end{array}$} \\
\hline H2 & & $1 / 2$ & $1 / 8$ & \multicolumn{2}{|c|}{$\begin{array}{l}\text { Restart after moving generator to a } \\
\text { location outside of kitchen where } \\
\text { CO enters home; generator does not } \\
\text { shutoff until the tank is empty. }\end{array}$} & \multicolumn{2}{|c|}{$\begin{array}{l}\text { The door between outside and kitchen } \\
\text { is open } 10 \mathrm{~cm} \text {. }\end{array}$} \\
\hline
\end{tabular}


Table 6.c.i. Scenarios for Houses with Garage and Basement but no Crawlspace, with Generator Initially Operated in Garage, with Generator Exhaust Oriented Away from Door to House Interior [Scenario weight total to $3 / 4$ ]

\begin{tabular}{|c|c|c|c|c|c|c|c|c|}
\hline \multicolumn{3}{|c|}{ Structure Type: } & & use & $\begin{array}{c}\text { Garage: } \\
\text { Yes }\end{array}$ & & Basement: Yes & $\begin{array}{l}\text { Crawlspace: } \\
\text { No }\end{array}$ \\
\hline \multicolumn{3}{|c|}{ Initial Location: } & \multicolumn{3}{|c|}{ Garage } & \multicolumn{3}{|c|}{$\begin{array}{l}\text { Weight for Home Type: (\# deaths allocated to this } \\
\text { home * \% this location) }\end{array}$} \\
\hline \multicolumn{3}{|c|}{ Initial Conditions: } & \multicolumn{6}{|c|}{$\begin{array}{l}\text { Door to interior of house is open } 10 \mathrm{~cm} \text {. Bay door is fully closed. Generator is in center of } \\
\text { garage. Exhaust is facing away from the door to house interior. }\end{array}$} \\
\hline \multicolumn{9}{|c|}{ Restart Scenarios } \\
\hline Scenario & $\begin{array}{l}\text { Scenario } \\
\text { Weight }\end{array}$ & $\begin{array}{l}\text { Sub-Scenario } \\
\text { Weight }\end{array}$ & Weight & \multicolumn{3}{|c|}{ Response to Shutoff } & \multicolumn{2}{|c|}{ Changes from Initial Conditions } \\
\hline I & $1 / 4$ & 1 & $1 / 4$ & \multicolumn{3}{|c|}{ No restart } & \multicolumn{2}{|l|}{ N/A } \\
\hline $\mathrm{J} 1$ & \multirow{2}{*}{$1 / 4$} & $1 / 2$ & $1 / 8$ & \multicolumn{3}{|c|}{ Restart in garage. } & \multicolumn{2}{|l|}{ None. } \\
\hline $\mathrm{J} 2$ & & $1 / 2$ & $1 / 8$ & \multicolumn{3}{|c|}{ Restart in garage. } & \multicolumn{2}{|c|}{ Bay door fully open. } \\
\hline K1 & \multirow[t]{2}{*}{$1 / 4$} & $1 / 2$ & $1 / 8$ & \multicolumn{3}{|c|}{$\begin{array}{l}\text { Restart after moving generator to } \\
\text { location outside of garage where } \\
\text { CO does not enter home; generator } \\
\text { does not shutoff until the tank is } \\
\text { empty. }\end{array}$} & \multicolumn{2}{|c|}{$\begin{array}{l}\text { Occupant opens bay door to remove } \\
\text { generator and then closes it } 2 \text { minutes } \\
\text { later. Door to house interior is open } 10 \\
\mathrm{~cm} \text {. }\end{array}$} \\
\hline K2 & & $1 / 2$ & $1 / 8$ & \multicolumn{3}{|c|}{$\begin{array}{l}\text { Restart after moving generator to a } \\
\text { location outside of garage where } \\
\text { CO enters home; generator does not } \\
\text { shutoff until the tank is empty. }\end{array}$} & \multicolumn{2}{|c|}{$\begin{array}{l}\text { Bay door is fully open and exhaust is } \\
\text { pointed into garage. Door to house } \\
\text { interior is open } 10 \mathrm{~cm} \text {. }\end{array}$} \\
\hline
\end{tabular}


Table 6.c.ii. Scenarios for Houses with Garage and Basement but no Crawlspace, with Generator Initially Operated in Garage, with Generator Exhaust Oriented Towards Door to House Interior [Scenario weight total to $1 / 4$ ]

\begin{tabular}{|c|c|c|c|c|c|c|c|c|}
\hline \multicolumn{3}{|c|}{ Structure Type: } & & use & $\begin{array}{c}\text { Garage: } \\
\text { Yes }\end{array}$ & & Basement: Yes & $\begin{array}{l}\text { Crawlspace: } \\
\text { No }\end{array}$ \\
\hline \multicolumn{3}{|c|}{ Initial Location: } & \multicolumn{3}{|c|}{ Garage } & \multicolumn{3}{|c|}{$\begin{array}{l}\text { Weight for Home Type: (\# deaths allocated to this } \\
\text { home * \% this location) }\end{array}$} \\
\hline \multicolumn{3}{|c|}{ Initial Conditions: } & \multicolumn{6}{|c|}{$\begin{array}{l}\text { Door to interior of house is open } 10 \mathrm{~cm} \text {. Bay door is fully closed. Generator is in center of } \\
\text { garage. Exhaust is facing towards door to house interior. }\end{array}$} \\
\hline \multicolumn{9}{|c|}{ Restart Scenarios } \\
\hline Scenario & $\begin{array}{l}\text { Scenario } \\
\text { Weight }\end{array}$ & $\begin{array}{l}\text { Sub-Scenario } \\
\text { Weight }\end{array}$ & Weight & \multicolumn{3}{|c|}{ Response to Shutoff } & \multicolumn{2}{|c|}{ Changes from Initial Conditions } \\
\hline $\mathrm{L}$ & $1 / 12$ & 1 & $1 / 12$ & \multicolumn{3}{|c|}{ No restart } & \multicolumn{2}{|l|}{ N/A } \\
\hline M1 & \multirow{2}{*}{$1 / 12$} & $1 / 2$ & $1 / 24$ & \multicolumn{3}{|c|}{ Restart in garage. } & \multicolumn{2}{|l|}{ None. } \\
\hline M2 & & $1 / 2$ & $1 / 24$ & \multicolumn{3}{|c|}{ Restart in garage. } & \multicolumn{2}{|c|}{ Bay door fully open. } \\
\hline N1 & \multirow[t]{2}{*}{$1 / 12$} & $1 / 2$ & $1 / 24$ & \multicolumn{3}{|c|}{$\begin{array}{l}\text { Restart after moving generator to } \\
\text { location outside of garage where } \\
\text { CO does not enter home; generator } \\
\text { does not shutoff until the tank is } \\
\text { empty. }\end{array}$} & \multicolumn{2}{|c|}{$\begin{array}{l}\text { Occupant opens bay door to remove } \\
\text { generator and then closes it } 2 \text { minutes } \\
\text { later. Door to house interior is open } 10 \\
\mathrm{~cm} .\end{array}$} \\
\hline N2 & & $1 / 2$ & $1 / 24$ & \multicolumn{3}{|c|}{$\begin{array}{l}\text { Restart after moving generator to a } \\
\text { location outside of garage where } \\
\text { CO enters home; generator does not } \\
\text { shutoff until the tank is empty. }\end{array}$} & \multicolumn{2}{|c|}{$\begin{array}{l}\text { Bay door is fully open and exhaust is } \\
\text { pointed into garage. Door to house } \\
\text { interior is open } 10 \mathrm{~cm} \text {. }\end{array}$} \\
\hline
\end{tabular}

Table 6.d. Scenario for Houses with Garage and Basement but no Crawlspace, with Generator Initially Operated Outside

\begin{tabular}{|c|c|c|c|c|c|c|c|c|}
\hline \multicolumn{3}{|c|}{ Structure Type: } & \multicolumn{3}{|r|}{$\begin{array}{l}\text { Garage: } \\
\text { Yes }\end{array}$} & \multicolumn{2}{|r|}{ Basement: Yes } & $\begin{array}{l}\text { Crawlspace: } \\
\text { No }\end{array}$ \\
\hline \multicolumn{3}{|c|}{ Initial Location: } & \multicolumn{3}{|c|}{ Outside } & \multicolumn{3}{|c|}{$\begin{array}{c}\text { Weight for Home Type: (\# deaths outside this } \\
\text { home type) }\end{array}$} \\
\hline \multicolumn{3}{|c|}{ Initial Conditions: } & \multicolumn{6}{|c|}{$\begin{array}{l}\text { Exterior door to kitchen is open } 10 \mathrm{~cm} \text {. Start generator in a location outside of kitchen } \\
\text { where CO enters home. }\end{array}$} \\
\hline \multicolumn{9}{|c|}{ Restart Scenarios } \\
\hline Scenario & $\begin{array}{l}\text { Scenario } \\
\text { Weight }\end{array}$ & $\begin{array}{c}\text { Sub-Scenario } \\
\text { Weight }\end{array}$ & Weight & \multicolumn{3}{|c|}{ Response to Shutoff } & \multicolumn{2}{|c|}{ Changes from Initial Conditions } \\
\hline $\mathrm{P}$ & $\begin{array}{l}\text { Actual } \\
\text { Deaths } \\
\text { for } \\
\text { specific } \\
\text { house } \\
\text { model } \\
\end{array}$ & - & $\begin{array}{l}\text { Actual } \\
\text { Deaths for } \\
\text { specific } \\
\text { house } \\
\text { model }\end{array}$ & \multicolumn{3}{|c|}{$\begin{array}{l}\text { Note: generator does not shutoff } \\
\text { until the tank is empty; therefore, } \\
\text { there are no restart scenarios. }\end{array}$} & \multicolumn{2}{|l|}{ N/A } \\
\hline
\end{tabular}


Table 7. Scenarios for Detached 1-Car and 2-Car Garages (GAR1 and GAR2) with Generator Operated in Garage

\begin{tabular}{|c|c|c|c|c|c|}
\hline \multirow{2}{*}{\multicolumn{3}{|c|}{$\begin{array}{l}\text { Structure Type: } \\
\text { Initial Location: }\end{array}$}} & \multicolumn{3}{|c|}{ GAR1 \& GAR2 } \\
\hline & & & & Weight & $\begin{array}{l}\text { r Structure Type: (\# deaths allocated to } \\
\text { is structure * \% this location) }\end{array}$ \\
\hline \multicolumn{3}{|c|}{ Initial Conditions: } & \multicolumn{3}{|c|}{ Bay door is closed. Generator is in center of garage. } \\
\hline \multicolumn{6}{|c|}{ Restart Scenarios } \\
\hline Scenario & $\begin{array}{c}\text { Scenario } \\
\text { Weight }\end{array}$ & $\begin{array}{l}\text { Sub-Scenario } \\
\text { Weight }\end{array}$ & Weight & Response to Shutoff & Changes from Initial Conditions \\
\hline A & $1 / 3$ & 1 & $1 / 3$ & No restart & N/A \\
\hline B1 & \multirow{2}{*}{$1 / 3$} & $1 / 2$ & $1 / 6$ & Restart in garage. & None. \\
\hline B2 & & $1 / 2$ & $1 / 6$ & Restart in garage. & Bay door fully open. \\
\hline $\mathrm{C} 1$ & \multirow{2}{*}{$1 / 3$} & $1 / 2$ & $1 / 6$ & $\begin{array}{l}\text { Restart after moving generator to } \\
\text { location outside of garage where } \\
\text { CO does not enter garage; } \\
\text { generator does not shutoff. }\end{array}$ & $\begin{array}{l}\text { Occupant opens bay door to remove } \\
\text { generator and then closes it } 2 \text { minutes } \\
\text { later. }\end{array}$ \\
\hline C2 & & $1 / 2$ & $1 / 6$ & $\begin{array}{l}\text { Restart after moving generator to a } \\
\text { location outside of garage where } \\
\text { CO enters garage; generator does } \\
\text { not shutoff. }\end{array}$ & $\begin{array}{l}\text { Bay door is open fully and exhaust is } \\
\text { pointed into garage. }\end{array}$ \\
\hline
\end{tabular}


Table 8.a. Scenarios for Detached Garage with Workshop Room in it (GAR3), with Generator Initially Operated in Workshop Room

\begin{tabular}{|c|c|c|c|c|c|c|}
\hline \multirow{2}{*}{\multicolumn{3}{|c|}{$\begin{array}{l}\text { Structure Type: } \\
\text { Initial Location: }\end{array}$}} & \multicolumn{4}{|c|}{ GAR3 } \\
\hline & & & Workshc & oom in detached garage & Weight & $\begin{array}{l}\text { r Structure Type: (\# deaths allocated to } \\
\text { is structure * \% this location) }\end{array}$ \\
\hline \multicolumn{3}{|c|}{ Initial Conditions: } & \multicolumn{4}{|c|}{$\begin{array}{l}\text { Workshop room's door to garage is closed. Window in workshop room is closed. Bay door } \\
\text { is closed. }\end{array}$} \\
\hline \multicolumn{7}{|c|}{ Restart Scenarios } \\
\hline Scenario & $\begin{array}{c}\text { Scenario } \\
\text { Weight }\end{array}$ & $\begin{array}{l}\text { Sub-Scenario } \\
\text { Weight }\end{array}$ & Weight & Response to Sh & & Changes from Initial Conditions \\
\hline$E$ & $1 / 4$ & 1 & $1 / 4$ & No restart & & N/A \\
\hline $\mathrm{F} 1$ & \multirow{2}{*}{$1 / 4$} & $1 / 2$ & $1 / 8$ & \multirow{2}{*}{\multicolumn{2}{|c|}{$\begin{array}{l}\text { Restart in same room. } \\
\text { Restart in same room. }\end{array}$}} & None. \\
\hline F2 & & $1 / 2$ & $1 / 8$ & & & Window is open fully. \\
\hline G1 & \multirow{4}{*}{$1 / 4$} & $\begin{array}{l}3 / 4 * 1 / 2 \\
=3 / 8\end{array}$ & $3 / 32$ & \multicolumn{2}{|c|}{$\begin{array}{l}\text { Restart in garage. Exhaust facing } \\
\text { away from door to work room. }\end{array}$} & $\begin{array}{l}\text { Bay door closed. Door to work room is } \\
\text { open } 10 \mathrm{~cm} \text {. }\end{array}$ \\
\hline G2 & & $\begin{array}{l}1 / 4 * 1 / 2 \\
=1 / 8\end{array}$ & $1 / 32$ & \multicolumn{2}{|c|}{$\begin{array}{l}\text { Restart in garage. } \\
\text { Exhaust facing door to work room. }\end{array}$} & $\begin{array}{l}\text { Bay door closed. Door to work room is } \\
\text { open } 10 \mathrm{~cm} \text {. }\end{array}$ \\
\hline G3 & & $\begin{array}{l}3 / 4 * 1 / 2 \\
=3 / 8\end{array}$ & $3 / 32$ & \multicolumn{2}{|c|}{$\begin{array}{l}\text { Restart in garage. Exhaust facing } \\
\text { away from door to work room. }\end{array}$} & $\begin{array}{l}\text { Bay door is open fully. Door to work } \\
\text { room is open } 10 \mathrm{~cm} \text {. }\end{array}$ \\
\hline G4 & & $\begin{array}{l}1 / 4 * 1 / 2 \\
=1 / 8\end{array}$ & $1 / 32$ & \multicolumn{2}{|c|}{$\begin{array}{l}\text { Restart in garage. } \\
\text { Exhaust facing door to work room. }\end{array}$} & $\begin{array}{l}\text { Bay door is open fully. Door to } \\
\text { workshop room is open } 10 \mathrm{~cm} \text {. }\end{array}$ \\
\hline H1 & \multirow{2}{*}{$1 / 4$} & $1 / 2$ & $1 / 8$ & \multicolumn{2}{|c|}{$\begin{array}{l}\text { Restart after moving generator to } \\
\text { location outside of garage where } \\
\text { CO does not enter garage; } \\
\text { generator does not shutoff. }\end{array}$} & $\begin{array}{l}\text { Occupant opens bay door to remove } \\
\text { generator and then closes it } 2 \text { minutes } \\
\text { later. Door to workshop room is open } \\
10 \mathrm{~cm} \text {. }\end{array}$ \\
\hline $\mathrm{H} 2$ & & $1 / 2$ & $1 / 8$ & \multicolumn{2}{|c|}{$\begin{array}{l}\text { Restart after moving generator to a } \\
\text { location outside of garage where } \\
\text { CO enters garage; generator does } \\
\text { not shutoff. }\end{array}$} & $\begin{array}{l}\text { Bay door is open fully and exhaust is } \\
\text { pointed into garage. Door to workshop } \\
\text { room is open } 10 \mathrm{~cm} \text {. }\end{array}$ \\
\hline
\end{tabular}


Table 8.b.i. Scenarios for Detached Garage with Workshop Room in it (GAR3), with Generator Initially Operated in Garage, with Exhaust Oriented Away from Workshop Room [Scenario weight total to 3/4]

\begin{tabular}{|c|c|c|c|c|c|c|}
\hline \multicolumn{3}{|c|}{ Structure Type: } & \multicolumn{4}{|c|}{ GAR3 } \\
\hline \multicolumn{3}{|c|}{ Initial Location: } & \multicolumn{2}{|c|}{ Garage area in detached garage } & \multicolumn{2}{|c|}{$\begin{array}{l}\text { Weight for Structure Type: (\# deaths allocated to } \\
\text { this structure * \% this location) }\end{array}$} \\
\hline \multicolumn{3}{|c|}{ Initial Conditions: } & \multicolumn{4}{|c|}{$\begin{array}{l}\text { Bay door is closed. Door to workshop is open } 10 \mathrm{~cm} \text {. Generator is in center of garage. } \\
\text { Exhaust is facing away from door to workshop room. }\end{array}$} \\
\hline \multicolumn{7}{|c|}{ Restart Scenarios } \\
\hline Scenario & $\begin{array}{c}\text { Scenario } \\
\text { Weight }\end{array}$ & $\begin{array}{l}\text { Sub-Scenario } \\
\text { Weight }\end{array}$ & Weight & Response to $\mathrm{S}$ & & Changes from Initial Conditions \\
\hline A & $3 / 12$ & 1 & $3 / 12$ & No restart & & N/A \\
\hline B1 & \multirow{2}{*}{$3 / 12$} & $1 / 2$ & $3 / 24$ & \multicolumn{2}{|l|}{ Restart in garage. } & None. \\
\hline B2 & & $1 / 2$ & $3 / 24$ & \multicolumn{2}{|l|}{ Restart in garage. } & Bay door fully open. \\
\hline C1 & \multirow{2}{*}{$3 / 12$} & $1 / 2$ & $3 / 24$ & \multicolumn{2}{|c|}{$\begin{array}{l}\text { Restart after moving generator to } \\
\text { location outside of garage where } \\
\text { CO does not enter home; generator } \\
\text { does not shutoff. }\end{array}$} & $\begin{array}{l}\text { Occupant opens bay door to remove } \\
\text { generator and then closes it } 2 \text { minutes } \\
\text { later. }\end{array}$ \\
\hline C2 & & $1 / 2$ & $3 / 24$ & \multicolumn{2}{|c|}{$\begin{array}{l}\text { Restart after moving generator to a } \\
\text { location outside of garage where } \\
\text { CO enters home; generator does not } \\
\text { shutoff. }\end{array}$} & $\begin{array}{l}\text { Bay door is open fully and exhaust is } \\
\text { pointed into garage. The door in } \\
\text { garage to interior of house is open } 10 \\
\text { cm. }\end{array}$ \\
\hline
\end{tabular}


Table 8.b.ii. Scenarios for Detached Garage with Workshop Room in it (GAR3), with Generator Initially Operated in Garage, with Exhaust Oriented Toward Workshop Room [Scenario weight total to $1 / 4$ ]

\begin{tabular}{|c|c|c|c|c|c|c|}
\hline \multirow{2}{*}{\multicolumn{3}{|c|}{$\begin{array}{l}\text { Structure Type: } \\
\text { Initial Location: }\end{array}$}} & \multicolumn{4}{|c|}{ GAR3 } \\
\hline & & & \multicolumn{2}{|c|}{ Garage area in detached garage } & \multicolumn{2}{|c|}{$\begin{array}{l}\text { Weight for Home Type: (\# deaths allocated to this } \\
\text { home * \% this location) }\end{array}$} \\
\hline \multicolumn{3}{|c|}{ Initial Conditions: } & \multicolumn{4}{|c|}{$\begin{array}{l}\text { Bay door is closed. Door to workshop is open } 10 \mathrm{~cm} \text {. Generator is in center of garage. } \\
\text { Exhaust is toward door to workshop room. }\end{array}$} \\
\hline \multicolumn{7}{|c|}{ Restart Scenarios } \\
\hline Scenario & $\begin{array}{l}\text { Scenario } \\
\text { Weight }\end{array}$ & $\begin{array}{l}\text { Sub-Scenario } \\
\text { Weight }\end{array}$ & Weight & Response to $S$ & & Changes from Initial Conditions \\
\hline A & $1 / 12$ & 1 & $1 / 12$ & No restart & & N/A \\
\hline B1 & \multirow{2}{*}{$1 / 12$} & $1 / 2$ & $1 / 24$ & \multicolumn{2}{|l|}{ Restart in garage. } & None. \\
\hline B2 & & $1 / 2$ & $1 / 24$ & \multicolumn{2}{|l|}{ Restart in garage. } & Bay door fully open. \\
\hline C1 & \multirow{2}{*}{$1 / 12$} & $1 / 2$ & $1 / 24$ & \multicolumn{2}{|c|}{$\begin{array}{l}\text { Restart after moving generator to } \\
\text { location outside of garage where } \\
\text { CO does not enter home; generator } \\
\text { does not shutoff. }\end{array}$} & $\begin{array}{l}\text { Occupant opens bay door to remove } \\
\text { generator and then closes it } 2 \text { minutes } \\
\text { later. }\end{array}$ \\
\hline C2 & & $1 / 2$ & $1 / 24$ & \multicolumn{2}{|c|}{$\begin{array}{l}\text { Restart after moving generator to a } \\
\text { location outside of garage where } \\
\text { CO enters home; generator does not } \\
\text { shutoff. }\end{array}$} & $\begin{array}{l}\text { Bay door is open fully and exhaust is } \\
\text { pointed into garage. The door in } \\
\text { garage to interior of house is open } 10 \\
\text { cm. }\end{array}$ \\
\hline
\end{tabular}

Tables 2.a. through 8.b.ii. contain, when accounting for all 40 building models (37 houses that fit into one of the 5 house groups and 3 detached garages), over 900 scenarios and these will result in more than 1 million simulations once all the weather conditions, shutoff criteria (including lack thereof for the baseline generator), and generator characteristics, all of which are discussed in the following sections, are accounted for with each scenario. To reduce the number of simulations to a more manageable size, NIST and CPSC staff may consider strategies such as taking a statistical sampling of the fatal CO incidents and applying weighting factors a priori or merging modeling efforts that would most likely yield similar results. Additional options to reduce the number of simulations may also be considered.

\section{Weather Conditions}

As mentioned previously in sections 1 and 2, weather affects how quickly the CO will accumulate in, transport through, and leave a house. Therefore, each scenario will be simulated with the building model being subjected to 28 different days of weather conditions that vary on an hourly basis by outdoor temperature, wind speed and wind direction. These 28 days of weather (used in the NIST TN 1925 study) correspond to two weeks of cold weather (due to the observed frequency of events in CPSC's incident data during the winter season), one week of warm weather and one week of mild weather. The hourly weather data for these three conditions were a subset of typical weather files for the following three cities: Detroit, MI (cold); Miami, FL (warm); and Columbus, 
$\mathrm{OH}$ (mild). The files were obtained from the EnergyPlus Energy Simulation Software website: https://energyplus.net/weather. Table 9 presents a summary of the weather conditions for the 28 days in the form of daily average, minimum and maximum outdoor temperatures and wind speeds.

A CONTAM model of a building is associated with a terrain shielding coefficient to account for the impacts of surrounding terrain, buildings and vegetation on surface-averaged, wind-induced pressures on the exterior façade of the building. CONTAM specifies three categories of terrain for flat exposed areas (e.g., airport), suburban, and dense urban centers, and a user can input coefficients to capture a range of terrain options in between the flat and urban extremes. As was done in NIST TN 1925, the simulations will employ the suburban category of terrain shielding, which corresponds to areas with obstructions of the size and spacing of single-family homes. The houses will be oriented such that the predominant wind direction for the simulated weather conditions will be directed toward the garage door for houses with garages or toward the front of the house for houses without garages. 
Table 9. Summary of Hourly Weather Data Used in Simulations

\begin{tabular}{|c|c|c|c|c|c|c|}
\hline \multirow[t]{2}{*}{ Day } & \multicolumn{3}{|c|}{ Outdoor temperature, ${ }^{\circ} \mathrm{C}\left({ }^{\circ} \mathrm{F}\right)$} & \multicolumn{3}{|c|}{ Wind speed, $\mathrm{m} / \mathrm{s}$ (mph) } \\
\hline & Average & Minimum & Maximum & Average & Minimum & Maximum \\
\hline 1-Jan & $0.7(33.3)$ & $-1.7(28.9)$ & $5.6(42.1)$ & $3.2(7.2)$ & $0.0(0.0)$ & $5.7(12.8)$ \\
\hline 2-Jan & $6.1(43.1)$ & $0.0(32.0)$ & $12.2(54.0)$ & $3.9(8.8)$ & $2.1(4.7)$ & $5.7(12.8)$ \\
\hline 3-Jan & $2.5(36.6)$ & $1.1(34.0)$ & $4.4(39.9)$ & $3.1(6.8)$ & $2.1(4.7)$ & $4.1(9.2)$ \\
\hline 4-Jan & $0.9(33.6)$ & $0.0(32.0)$ & $1.7(35.1)$ & $2.9(6.6)$ & $0.0(0.0)$ & $4.6(10.3)$ \\
\hline 5-Jan & $-2.9(26.8)$ & $-5.0(23.0)$ & $0.0(32.0)$ & $5.8(13.1)$ & $4.1(9.2)$ & $8.2(18.3)$ \\
\hline 6-Jan & $-3.3(26.1)$ & $-5.0(23.0)$ & $-1.7(28.9)$ & $5.2(11.6)$ & $1.5(3.4)$ & $8.2(18.3)$ \\
\hline 7-Jan & $-3.8(25.2)$ & $-6.1(21.0)$ & $-2.2(28.0)$ & $3.2(7.2)$ & $0.0(0.0)$ & $5.2(11.6)$ \\
\hline 8-Jan & $-1.7(28.9)$ & $-3.3(26.1)$ & $0.0(32.0)$ & $2.4(5.3)$ & $0.0(0.0)$ & $5.2(11.6)$ \\
\hline 9-Jan & $-0.1(31.8)$ & $-1.7(28.9)$ & $1.1(34.0)$ & $3.5(7.7)$ & $1.5(3.4)$ & 6.2 (13.9) \\
\hline 10-Jan & $1.8(35.3)$ & $1.0(33.8)$ & $2.8(37.0)$ & $3.5(7.7)$ & $0.0(0.0)$ & $6.7(15.0)$ \\
\hline 11-Jan & $0.6(33.0)$ & $-0.6(30.9)$ & $1.1(34.0)$ & $4.3(9.5)$ & $0.0(0.0)$ & $5.7(12.8)$ \\
\hline 12-Jan & $4.9(40.7)$ & $0.6(33.1)$ & $13.3(55.9)$ & $3.9(8.7)$ & $0.0(0.0)$ & 8.8 (19.7) \\
\hline 13-Jan & $9.2(48.5)$ & $0.6(33.1)$ & $14.4(57.9)$ & $6.4(14.3)$ & $2.6(5.8)$ & $10.3(23.0)$ \\
\hline 14-Jan & $-5.5(22.2)$ & $-9.4(15.1)$ & $1.1(34.0)$ & $5.3(11.9)$ & $2.6(5.8)$ & $7.2(16.1)$ \\
\hline 3-Apr & $6.0(42.7)$ & $2.8(37.0)$ & $8.3(46.9)$ & 6.9 (15.5) & $0.0(0.0)$ & $9.8(21.9)$ \\
\hline 4-Apr & $6.3(43.3)$ & $-0.6(30.9)$ & $13.3(55.9)$ & $2.1(4.7)$ & $0.0(0.0)$ & $5.7(12.8)$ \\
\hline 5-Apr & $9.0(48.1)$ & $1.1(34.0)$ & $15.6(60.1)$ & $1.8(4.0)$ & $0.0(0.0)$ & $3.6(8.1)$ \\
\hline 6-Apr & $11.9(53.4)$ & $5.0(41.0)$ & $18.9(66.0)$ & $3.7(8.3)$ & $2.1(4.7)$ & $6.2(13.9)$ \\
\hline 7-Apr & $16.2(61.1)$ & $11.1(52.0)$ & $22.8(73.0)$ & $5.4(12.1)$ & $0.0(0.0)$ & $12.4(27.7)$ \\
\hline 8-Apr & $11.0(51.8)$ & $7.0(44.6)$ & $13.9(57.0)$ & $6.0(13.5)$ & $0.0(0.0)$ & $9.8(21.9)$ \\
\hline 9-Apr & $8.5(47.3)$ & $3.9(39.0)$ & 13.3 (55.9) & $5.5(12.4)$ & $0.0(0.0)$ & $8.2(18.3)$ \\
\hline 25-Jul & $28.5(83.2)$ & $25.6(78.1)$ & 33.3 (91.9) & $2.5(5.7)$ & $1.0(2.2)$ & $5.2(11.6)$ \\
\hline 26-Jul & 29.3 (84.8) & $25.0(77.0)$ & $35.0(95.0)$ & $3.4(7.6)$ & $1.5(3.4)$ & $7.2(16.1)$ \\
\hline 27-Jul & $29.5(85.2)$ & $25.0(77.0)$ & $35.0(95.0)$ & $2.5(5.7)$ & $1.5(3.4)$ & $6.2(13.9)$ \\
\hline 28-Jul & $30.0(86.1)$ & $25.6(78.1)$ & $35.6(96.1)$ & $3.0(6.7)$ & $1.0(2.2)$ & $5.2(11.6)$ \\
\hline 29-Jul & 28.5 (83.3) & $25.6(78.1)$ & $33.9(93.0)$ & $3.3(7.3)$ & $1.0(2.2)$ & $11.3(25.3)$ \\
\hline 30-Jul & $29.2(84.5)$ & $26.1(79.0)$ & 33.3 (91.9) & $3.0(6.7)$ & $1.0(2.2)$ & 6.2 (13.9) \\
\hline 31-Jul & $29.0(84.1)$ & $27.8(82.0)$ & 31.7 (89.1) & $4.3(9.6)$ & $0.0(0.0)$ & $8.2(18.3)$ \\
\hline
\end{tabular}




\section{CO Concentration Criteria for Shutoff}

Both PGMA G300 and UL 2201 specify two CO concentration limits when shutoff must occur: an instantaneous value and a time-averaged value. The simulations will use the shutoff criteria as written in each standard for one set of runs, as well as $50 \%$ of the required shutoff concentrations for each standard for another set of runs. This study includes simulations using $50 \%$ of the specified shutoff concentrations because CPSC staff anticipates that some manufacturers may design systems with lower shutoff concentrations to ensure compliance with the requirements. Therefore, a total of four sets of shutoff criteria will be used in the simulations. In addition, current generators will be simulated with no shutoff criteria, hereafter referred to as baseline generators.

PGMA G300 requires a generator to shut off before the concentration of the measured CO exceeds an instantaneous value of 800 ppmv or a 10 minute rolling average of 400 ppmv. In addition, simulations will be performed where a G300 compliant generator will shut down before the CO concentration exceeds an instantaneous value of 400 parts per million or a rolling 10 minute average of 200 ppmv. The rolling average is calculated in accordance with Section 3.9.1 of PGMA G300 as shown below:

where,

$$
M_{t}=\frac{x_{t}+x_{t-1}+\cdots+x_{t-N+1}}{N}
$$

$M_{t}=$ Rolling average @ time $t$ (ppmv)

$x=$ Measured values taken by the onboard sensor (ppmv)

$N=$ Number of meaurements

UL 2201 requires a generator to shut off when the measured CO reaches an instantaneous value of $400 \mathrm{ppmv}$ or a rolling 600 second average measured at a frequency of $1 \mathrm{~Hz}$ reaches $150 \mathrm{ppmv}$. In addition, simulations will be performed where a UL 2201 compliant generator will shut down when the measured CO reaches an instantaneous value of 200 ppmv or a rolling 600 second average of 75 ppmv.

Table 10 provides the four sets of shutoff criteria that will be used in the simulations.

Table 10. Shutoff Criteria for Simulations

\begin{tabular}{|c|c|c|c|c|}
\hline & $\begin{array}{c}\text { PGMA G300 } \\
\text { Criteria (ppmv) }\end{array}$ & $\begin{array}{c}\text { 50 \% of PGMA } \\
\text { G300 Criteria } \\
\text { (ppmv) }\end{array}$ & $\begin{array}{c}\text { UL 2201 } \\
\text { Criteria } \\
\text { (ppmv) }\end{array}$ & $\begin{array}{c}\text { 50 \% of UL 2201 } \\
\text { Criteria (ppmv) }\end{array}$ \\
\hline Instantaneous & $>800$ & $>400$ & 400 & 200 \\
\hline $\begin{array}{c}\text { 10-min rolling } \\
\text { average }\end{array}$ & $>400$ & $>200$ & 150 & 75 \\
\hline
\end{tabular}




\section{Generator Characteristics}

The simulation inputs associated with the generator include $\mathrm{CO}$ emission rate, heat release rate, and run time on a full tank of gas (to account for situations where the generator does not shut off). As done in NIST TN 1925, generators will be divided into four size ranges, distinguished by the engine powering the generator using the U.S. Environmental Protection Agency (EPA) definitions for classification of engines in portable generators typically used by consumers: Handheld generators (powered by spark-ignited (SI) Handheld engines), Class 1 generators (powered by SI Class I non-handheld engines), Class 2 generators distinguished by either single cylinder or twin cylinder (powered by SI Class II non-handheld engines, referred to as Class 2 single cylinder or twin cylinder generators). ${ }^{3}$

Table 11 contains the $\mathrm{CO}$ emission rates at normal oxygen levels, heat release rates and run times that will be used in the simulations. Detailed descriptions of how these values were derived are provided in Appendix A in TAB K in Briefing Package for the NPR, 2016.

Table 11. Generator CO emission rates, run-times and heat release rates

\begin{tabular}{|l|c|c|c|c|}
\hline $\begin{array}{c}\text { Generator Size } \\
\text { Category }\end{array}$ & $\begin{array}{c}\text { Average Weighted } \\
\text { CO Rate for Baseline } \\
\text { and PGMA G300 } \\
\text { Generators } \\
\mathbf{( g / h )}\end{array}$ & $\begin{array}{c}\text { Average Weighted } \\
\text { CO Rate for UL } \\
\text { 2201 Generators } \\
\mathbf{( g / h )}\end{array}$ & $\begin{array}{c}\text { Average Run } \\
\text { Time for 50\% } \\
\text { Load on Full } \\
\text { Tank } \\
\text { (h) }\end{array}$ & $\begin{array}{c}\text { Average Heat } \\
\text { Release Rate for } \\
\mathbf{5 0 \%} \text { Load } \\
\mathbf{( k W )}\end{array}$ \\
\hline Handheld & 300 & 150 & 8 & 2 \\
\hline Class 1 & 600 & 150 & 9 & 6 \\
\hline Class 2 single cylinder & 1570 & 150 & 10 & 13 \\
\hline Class 2 twin cylinder & 3030 & 150 & 9 & 25 \\
\hline
\end{tabular}

\footnotetext{
${ }^{3}$ Per 40 C.F.R. § 1054.801, the EPA broadly categorizes small SI engines as either Nonhandheld or Handheld and within each of those categories further distinguishes them into different classes, which are based upon engine displacement. Nonhandheld engines are divided into Class I and Class II, with Class I engines having displacement above 80 cubic centimeters (cc) up to 225 cc and Class II having displacement at or above 225 cc but maximum power of 19 kilowatts $(\mathrm{kW})$. Handheld engines, which are divided into Classes III, IV, and V, are all at or below 80 cc. Some Handheld engines are used to power very small portable generators, but the vast majority are powered by Class I and Class II engines. Class II single cylinder engines typically power generators with $3.5 \mathrm{~kW}$ up to and including $9 \mathrm{~kW}$ rated power output. These are referred to as Class 2 single cylinder generators in this report. Class II twin cylinder engines typically power generators over $9 \mathrm{~kW}$ rated power, potentially up to nominally $18 \mathrm{~kW}$. These are referred to as Class 2 twin cylinder generators in this report. Class I engines typically power generators with rated power of $2 \mathrm{~kW}$ to just under $3.5 \mathrm{~kW}$ rated power and are referred to as Class 1 generators in this report. Handheld engines typically power generators with rated power below $2 \mathrm{~kW}$ and are referred to as Handheld generators in this report (CPSC Staff Briefing Package 2016).
} 


\section{Simulation Methodology}

All of the scenarios defined in section 4 will be simulated in each of 40 building models for a 24hr period over a range of 28 different days of weather conditions, 2 sets of shutoff criteria (full and half values as described in Section 6) associated with four CO emission rates/runtimes/heat release rates for each of the 2 voluntary standards, and with no shutoff criteria for baseline generators. The simulations will use the $\mathrm{CO}$ emission rates in Table 11 with the rate increased by a factor of 3 times the $\mathrm{CO}$ emission rate at normal oxygen after 2 hours of operation, to reflect reduced $\mathrm{O}_{2}$ levels associated with operation in rooms without open windows or doors (as described in NIST TN 1925). For scenarios with the generator started outside (or restarted in a location outside that could allow CO entry), the CO entry into the house will be modeled based on the methodology of the validation case 51 of Technical Note 2049. Specifically, a CO source will be located in either the kitchen or garage with a $\mathrm{CO}$ emission rate at a fraction of the full Table 11 rate. The same fraction will be used for all generators located outside.

In all simulations, the generators will be started at the beginning of the simulation period and will run until one tank of gas is used if the shutoff criteria do not turn off the generator either initially or after any prescribed restart. For a restart scenario, the generator will be restarted after a 10minute delay as was done in the experiments described in NIST TN 2049. All simulations will use a one second time step in simulating the time of shutoff and will report CO concentrations in the rooms of each house for each minute during the 24-hour analysis interval. These one-minute concentrations will then be used to calculate $\mathrm{COHb}$ values for an occupant in each occupiable zone (i.e., all rooms except bathrooms, stairs, and hallways). COHb levels will be calculated and reported in the same manner as in NIST TN 1925 using the Coburn-Forster-Kane (CFK) nonlinear differential equation (Peterson and Stewart 1975, Coburn et al. 1965), which is provided in Appendix 2 of NIST TN 2049. Input values for these calculations, determined by CPSC, include an RMV (respiratory minute volume) value of $10 \mathrm{~L} / \mathrm{min}$ (representing a time-weighted average 24 hour value for males and females 16 to 80 years old, for expected residential indoor activity). The COHb levels will then be analyzed, as describe in section 9 .

As shown for the tests reported in NIST TN 2049, generator operation in the test house consistently resulted in non-uniform CO concentrations near the generator due in large part to the generator heat release and exhaust velocity. Tables 2 through 7 in that report show the ratio of the zone average $\mathrm{CO}$ concentration to the shutoff sensor concentration at the time of shutoff. The ratio was calculated using the 10-minute average if the shutoff was based on the average concentration and the instantaneous concentration if the shutoff was based on the instantaneous value. The simulations will account for local non-uniformities using the shutoff ratio methodology applied in validation case 5 of TN 2049 which resulted in improved agreement between the simulations and measurements. Specifically, the CO concentration in the CONTAM zone with the generator will be divided by a factor based on the values reported in TN 2049 to account for the fact that the CO concentration was consistently lower than the zone average at the elevation of a shutoff sensor located on the generator. Separate factors will be used for the instantaneous and 10-minute average shutoff criteria. 
Exhaust orientation is another critical factor when deciding whether the source zone and the shutoff measurement zone are the same room. The space (zone) where exhaust constituents accumulate directly because of the exhaust jet is called the source zone in this discussion. The zone containing the generator and the shutoff measurement is called the shutoff measurement zone. Other zones will also accumulate CO due to interzonal airflow. The source zone and the shutoff measurement zone are assumed to be the same when exhaust from the exhaust jet initially accumulates in the same room as the generator (e.g., many cases when the exhaust is pointed towards a wall without a doorway). If the exhaust is oriented such that the exhaust jet pushes a significant amount of the exhaust constituents into an adjacent zone. which may occur when the exhaust is pointed directly at a doorway, then this adjacent zone is considered the source zone. Adjustments to the modeling approach are needed if the source zone is different than the shutoff measurement zone. When this condition exists, the shutoff ratio may not be used because the concentration of $\mathrm{CO}$ in the shutoff measurement zone will be more uniform as $\mathrm{CO}$ diffuses in from the adjacent source zone. Airflow in the shutoff measurement zone is less affected by the concentration gradient developed near the exhaust jet when most of the exhaust jet is in an adjacent room. In many scenarios in which exhaust orientation is not specified, meaning the exhaust is not directed at a doorway, no adjustments other than use of the shutoff ratio are needed because the source zone and shutoff measurement zone are assumed to be the same.

Exhaust orientations are only specified for scenarios where the generator is operated in the garage or in a first floor room where the exhaust is directed out of a doorway. These scenarios include conditions where the exhaust jet may push CO into another zone adjacent to the shutoff measurement zone. An example is provided in Figure 1, where the generator with shutoff sensor is located in bedroom 3 at the doorway with the exhaust pointed into the dining room. Scenarios where the generator is operated in the garage or in a first floor room include sub-scenarios where the exhaust is directed toward an open door. In these scenarios, it is possible that $\mathrm{CO}$ will accumulate more rapidly in the zone adjacent to the shutoff measurement zone (i.e., in the living space, rather than the garage). 


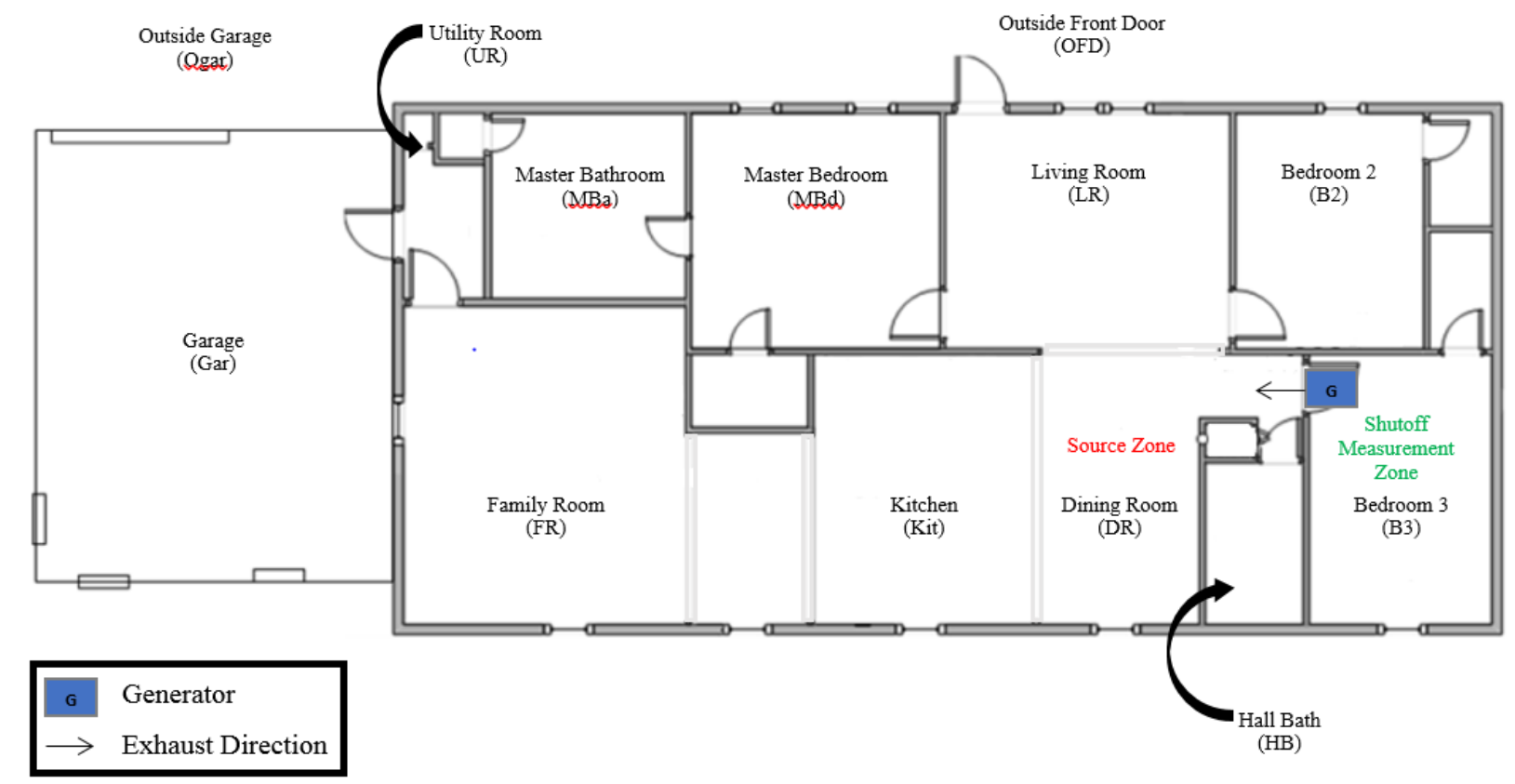

Figure 1. Case 17 of TN 2049, example of a source zone adjacent to a shutoff measurement zone.

To model scenarios where the exhaust jet pushes $\mathrm{CO}$ into an adjacent room, the CO source or a fraction of the total $\mathrm{CO}$ emission rate can be modeled in the source zone, with the shutoff measurement performed in the shutoff measurement zone such as was done for validation case 17 of NIST TN 2049 as shown in Figure 1. This approach can more accurately represent where the exhaust constituents will likely accumulate prior to moving to other zones. CPSC staff anticipates that scenarios with exhaust directed towards the adjacent room would impact less than $1 / 4$ of all modeled incidents, and in fact would likely be much less than that, because this scenario only affects incidents with the generator in the garage or other first floor room. 


\section{Analysis of COHb Profiles}

The approach that will be used for analyzing the simulation results will be similar to that which was used by CPSC staff for analyzing the effectiveness of the proposed rule. This current analysis is based on the concept of making a reasonable attempt to simulate fatal incidents reported in CPSC's incident data records and estimating the number of deaths that might have been avoided if the consumers had used a voluntary standard-compliant generator instead of one without any CO mitigation strategy. In addition, for the simulated survivors of scenarios that would have been fatal exposures with a baseline generator, the analysis will include estimating the severity of any $\mathrm{CO}$ injuries that may result from the reduced CO exposure.

The fatal incident data used as the basis for this study is described in section 9.1. The methodology that will be employed by CPSC staff to arrive at the estimates of effectiveness is described in section 9.2 and Appendix A of this report.

\subsection{Fatality Data used in the Analysis}

The incident data upon which the simulations will be based include 511 deaths that occurred in the 9-year period 2004 to 2012. 503 of these deaths occurred with the victim and generator in a structure for which NIST has an existing building model that reasonably represents the structure in which the incident occurred. These are the same 503 fatalities that were used in the benefits analysis for the proposed rule. Appendix B of TAB K of the CPSC staff briefing package for the NPR describes in detail how the 503 deaths were arrived at out of the total that occurred in that period.

Also included in the present effort are eight indoor fatalities that resulted from generators used in outdoor locations in that same 9-year period near structures represented in the simulations for the 503 deaths that are being included in this effort. The rationale to include these outdoor generator scenarios is the expectation that shutoff devices may not cause the generator to shut off when the generator is located outdoors. More detail on these eight fatalities and the involved structures is provided in Appendix A of this report.

\subsection{Methodology}

CPSC staff developed a methodology to process the simulations' output files containing the COHb data to estimate the number of deaths that might have been avoided and, for the deaths that were avoided, to estimate the potential severity of injuries that may have resulted instead of death. This methodology will be applied to the results from the simulations of each of the different shutoff criteria: one for the shutoff criteria in each voluntary standard and one for half the shutoff criteria in each voluntary standard. Full details of the analysis methodology are included in Appendix A of this report. 


\section{Acknowledgements}

NIST's participation in this effort was supported by an interagency agreement between NIST and CPSC (CPSC-I-17-0023). The authors would like to acknowledge the contributions of Sandy Inkster and Tim Smith from CPSC.

\section{References}

PGMA. 2018. ANSI/PGMA G300-2018, Safety and Performance of Portable Generators, available online at https://www.pgmaonline.com/pdf/ANSI_PGMAG300-2018.pdf

Burton, L.E. 1996. CPSC Health Sciences Memorandum, Toxicity from Low Level Human Exposure to Carbon Monoxide.

Clardy, P. F., et al. 2010. Official reprint from UpToDate on topic carbon monoxide poisoning, last updated October 28, 2010.

CPSC. 2016. CPSC Staff Briefing Package for Notice of Proposed Rulemaking For Safety Standard For Carbon Monoxide Hazard For Portable Generators, October 5, 2016. Available online at https://www.cpsc.gov/s3fspublic/Proposed_Rule_Safety_Standard_for_Portable_Generators_October_5_2016.pdf

DOE. 2005. Residential Energy Consumption Survey (RECS). ; Available from: http://www.eia.doe.gov/emeu/recs/contents.html.

Dols, W.S. and B.J. Polidoro. 2015. CONTAM 3.2 User Guide and Program Documentation. NIST Technical Note 1887. National Institute of Standards and Technology.

Emmerich, S.J. 2001. Validation of Multi-zone IAQ Modeling of Residential-Scale Buildings: A Review. ASHRAE Transactions. 107 (2): p.619-628.

Emmerich, S.J., C. Howard-Reed, and S.J. Nabinger. 2004. Validation of Multi-zone IAQ Model Predictions for Tracer Gas in a Townhouse. Building Service Engineering Research Technology. 25(4): p. 305-316.

Emmerich, S.J. 2006. Simulated Performance of Natural and Hybrid Ventilation Systems in an Office Building. International Journal of HVAC\&R Research Vol. 12 (4).

Emmerich, S.J. and W.S. Dols. 2016. Model Validation Study of Carbon Monoxide Transport due to Portable Generator Operation in an Attached Garage. Journal of Building Performance Simulation 9 (4), 397-410. 10. 
Emmerich, S.J., B. Polidoro, and W.S. Dols. 2016. Simulation of Residential Carbon Monoxide Exposure Due to Generator Operation in Enclosed Spaces. NIST Technical Note 1925.

Emmerich, S.J., S.M. Zimmerman, S.J. Nabinger, and M.J. Brookman. 2019. Characterization of Carbon Monoxide Concentrations and Calculated Carboxyhemoglobin Profiles of Occupants in a Test House from Portable Generators with a Simulated CO Safety Shutoff Device, NIST Technical Note 2049.

Hnatov M.V. 2018. Incidents, Deaths, and In-Depth Investigations Associated with Non-Fire Carbon Monoxide from Engine-Driven Generators and Other Engine-Driven Tools, 2005-2017; U.S. Consumer Product Safety Commission: Bethesda, MD.

Hnatov M.V. 2017. Non-Fire Carbon Monoxide Deaths Associated with the Use of Consumer Products, 2014 Annual Estimates, U.S. Consumer Product Safety Commission, Bethesda, MD.

Hnatov M.V. 2015. Incidents, Deaths, and In-Depth Investigations Associated with Non-Fire Carbon Monoxide from Engine-Driven Generators and Other Engine-Driven Tools, 2004-2014; U.S. Consumer Product Safety Commission: Bethesda, MD.

HUD. 1999. American Housing Survey for the United States. U.S. Department of Housing and Urban Development, U.S. Department of Commerce.

Persily, A.K., A. Musser, and D. Leber. 2006. A Collection of Homes to Represent the U.S. Housing Stock. NISTIR 7330. National Institute of Standards and Technology.

Poppendieck, D.G., S.S. Khurshid, W.S. Dols, L.C. Ng, B.J. Polidoro, and S.J. Emmerich. 2016. Formaldehyde Concentrations in a Net-Zero Energy House: Real-time Monitoring and Simulation. Proceedings of Indoor Air 2016.

Stewart, R.D. 1975. The effect of carbon monoxide on humans. Annual review of pharmacology. 15, 409-23.

UL.2018. UL. 2201-2018, Standard for Carbon Monoxide (CO) Emission Rate of Portable Generators.

Wang, L., W. S. Dols and Q. Chen. 2010. Using CFD Capabilities of CONTAM 3.0 for Simulating Airflow and Contaminant Transport In and Around Buildings. Science and Technology for the Built Environment - Special Edition “CFD Simulations in Buildings” 16(6): 16. 
Appendix A

Modeling Output and Analysis Methodology 


\section{A. Modeling Output and Analysis Methodology}

This Appendix describes how the COHb results discussed in the main body of this report will be further analyzed by CPSC staff to estimate the effectiveness of the voluntary standards. It includes a description of the analytical method and the factors used in that method.

\section{A.1 Scope}

The scope of CPSC staff's analysis of the NIST modeling results described in this report will be limited to a subset of the 659 non-work-related generator-related CO fatalities known to CPSC over the 9-year period 2004 -2012 that occurred at fixed residential structures or similar structures (i.e., cabins, barns, etc.). The subset represents about three quarters (77\%, 511 of 659) of the fatalities known to CPSC staff. 503 of these deaths occurred when the generator was used in a structure in which CPSC staff assessed NIST had a model that reasonably represented it. These 503 deaths were modeled by the simulations in NIST TN 1925 for the NPR (see Appendix B of TAB K of the CPSC staff briefing package for the NPR for details). The other 8 of the 511 fatalities that will be included in this planned analysis were associated with generators located outdoors of structures similar to one of the 37 homes already being modeled for the 503 deaths. The rationale behind the inclusion of the 8 fatalities is based on the assumption that the CO mitigation strategy being considered involves shut-off devices that may not activate when generators are located outdoors.

The remaining 148 generator-related CO fatalities are not within the scope of this analysis. These other reported scenarios include, but are not limited to, fatal incidents where a generator was used inside a structure not specifically modeled by NIST, such as inside churches, office buildings, or other non-residential structures; incidents where a generator was located inside of temporary habitats such as cabins, travel trailers, and recreational vehicles; and incidents in which a generator was used outside a structure that CPSC staff assessed is not represented by one of the 40 structures being modeled in this analysis. CPSC staff believes that CO emissions mitigation strategies, similar to those considered in this analysis, may have the potential to save lives in these other reported fatal scenarios that are not specifically addressed in this analysis.

\section{A.2 Effectiveness Analysis}

CPSC staff's effectiveness analysis will be based on the concept of estimating the number of deaths that might have been avoided if consumers had used a generator employing one of the $\mathrm{CO}$ mitigation strategies in the two voluntary standards in incident scenarios similar to those reported in CPSC's incident data records. Additionally, for the estimated deaths avoided, determinations are made, based on peak COHb levels, to estimate the level of injury, if any, that survivors would endure. NIST modelling results will be used to estimate $\mathrm{CO}$ levels and $\mathrm{COHb}$ levels resulting from baseline generators and those from generators employing the $\mathrm{CO}$ mitigation strategies in one of the two voluntary standards.

The CO mitigation strategies as described in the two voluntary standards either do not require an indicator identifying the reason the generator shut off (UL 2201) or only require the indicator to be visible for a limited time (i.e., 5 minutes) (PGMA G300). Due in part to these limitations, CPSC 
staff assumes that some consumers may attempt to restart the generators due to a lack of understanding of why the generator shut off or for other reasons including those provided in Section 4 of this report. The generator operation scenarios to be considered in the CPSC analysis (including restart) are provided in Tables 2.a. to 8.b.ii. in Section 4. These tables present the different options that CPSC staff believes are most likely for consumers to take. The scenario options are based on an assumed original generator location and reflect CPSC staff's best assessment of how the consumer would react to the generator shutting off. The options include:

- No restart, or

- Restart in the same location, or

- Move to a more isolated area and restart, or

- Move the generator outside and then restart.

Because generators that comply with the voluntary standards are just beginning to enter the market and have not been involved in incidents reported to CPSC that staff is aware of, CPSC staff assumes equal probability for each of these options.

In $48 \%$ of the fatal incidents, the specific details of the generator involved were not obtainable. CPSC staff assumed that the same proportions in these unknown generator category incidents would apply as those in which the generator type could be obtained. Therefore, the unknown generator category incident fatalities were allocated proportionately to the known cases.

Table A.2: Distribution of Known Fatalities and Allocated Fatalities by Generator Category

\begin{tabular}{|c|c|c|c|c|c|}
\hline & \multicolumn{2}{|c|}{ Generator Located Indoors } & \multicolumn{2}{|c|}{ Generator Located Outdoors } & \multirow[b]{2}{*}{$\begin{array}{c}\text { Total } \\
\text { Allocated } \\
\text { Fatalities }\end{array}$} \\
\hline $\begin{array}{l}\text { Generator } \\
\text { Category }\end{array}$ & $\begin{array}{c}\text { Known Fatalities - } \\
\text { Generator } \\
\text { Category Known }\end{array}$ & $\begin{array}{c}\text { Allocated } \\
\text { Fatalities for } \\
\text { Unknown } \\
\text { Generators } \\
\end{array}$ & $\begin{array}{c}\text { Known Fatalities - } \\
\text { Generator } \\
\text { Category Known }\end{array}$ & $\begin{array}{c}\text { Allocated } \\
\text { Fatalities for } \\
\text { Unknown } \\
\text { Generators } \\
\end{array}$ & \\
\hline Handheld & 2.0 & 1.7 & -- & -- & 3.7 \\
\hline Class 1 & 90.0 & 86.2 & 1 & 1.25 & 178.45 \\
\hline $\begin{array}{c}\text { Class } 2 \text { single } \\
\text { cylinder }\end{array}$ & 166.0 & 154.3 & 3 & 3.75 & 327.05 \\
\hline $\begin{array}{c}\text { Class } 2 \text { twin } \\
\text { cylinder }\end{array}$ & 1.0 & 0.8 & -- & -- & 1.8 \\
\hline Total & 259.0 & 243.0 & 4.0 & 5.0 & 511.0 \\
\hline
\end{tabular}

\section{A.3 Analytical Method}

The analytical methodology to be used in CPSC staff's effectiveness analysis is similar to the analysis used in the NPR for the 503 deaths modeled by the simulations reported in NIST TN 1925. Aside from the simulation changes as presented in the main body of this report, the only differences are the addition of: 
- restart scenarios,

- several outdoor scenarios associated with structures included in the simulation modelling (8 deaths), and

- added analyses of injuries from the lives saved.

The effectiveness analysis involves estimating the differential between the actual generatorassociated $\mathrm{CO}$ fatalities germane to this study and the number of predicted fatalities associated with a specific CO mitigation strategy. Therefore, this analysis compares the 503 indoor located generator-related fatalities plus the 8 outdoor located generator fatalities to the number for each of four specific sets of shutoff criteria. In addition to the potential lives saved for a given set of shutoff criteria, estimates of CO injuries and their severity will be determined. The four specific CO mitigation strategies being analyzed are:

1. The PGMA G300 voluntary standard as written requiring generators to shut off before the CO concentration exceeds 400 ppmv for a rolling 10 minute period or before an instantaneous measurement of 800 ppmv measured at a specific location above the generator,

2. One half the PGMA G300 requirements ( $200 \mathrm{ppm}$ of CO for a 10 minute period or an instantaneous reading of $400 \mathrm{ppm}$ ),

3. The UL 2201 voluntary standard as written requiring a maximum weighted CO emission rate of $150 \mathrm{~g} / \mathrm{h}$ and a requirement for generators to shut off when the CO concentration is either an average of $150 \mathrm{ppm}$ of $\mathrm{CO}$ for a 10 minute period or an instantaneous reading of 400 ppm measured at a specific location above the generator during performance testing, and

4. One half the UL 2201 requirements (75 ppm of CO for a 10 minute period or an instantaneous reading of $200 \mathrm{ppm}$ ) but maintaining the maximum weighted $\mathrm{CO}$ emission rate of $150 \mathrm{~g} / \mathrm{h}$.

This simulation plan includes one half of the specified shutoff criteria (items $2 \& 4$, above) to evaluate the impact of these alternate criteria if employed. These are being included because staff anticipates that some manufacturers may design systems with lower shutoff values to ensure compliance with the requirements in either standard.

In order for CPSC staff to estimate the effectiveness of each of the above-mentioned CO mitigation strategies, some or all of the following factors will be taken into account (depending on house/structure type and generator category):

1. Observed proportion of generator locations within house/structure model

2. Observed proportion of generator category involved by location within house/structure model (for example, the incident data shows that larger generators are more likely to be used in a garage while smaller, more portable generators are more often brought into the living spaces) 
3. Number of fatalities associated with house/structure model, including the allocation of unknown and non-exact match cases

4. Proportion of fatalities associated with generator category (Class 1 and Class 2 single cylinder generator categories only)

5. Simulated fatality rates by occupied zone

6. On a per house/structure basis, the actual fatalities (based on assumed CO rate for specific generator category) minus simulated fatalities from generators complying with specific $\mathrm{CO}$ mitigation strategies.

7. Restart scenarios based on CPSC staff's assessment of consumer actions taken after shutoff including no restart.

8. On a per house/structure basis, an assessment of simulated injuries from generators complying with specific CO mitigation strategies.

The methodology steps and the general equations used by CPSC staff to estimate deaths averted are as follows (which is the same as used in the NPR and uses the same COHb criteria to determine fatality), starting with the following nomenclature and definitions:

$A_{j}=$ Allotted Fatalities for $j^{\text {th }}$ Structure

$\mathrm{B}_{\mathrm{k}}=\%$ by $\mathrm{k}^{\text {th }}$ generator category (structure specific considerations)

$C_{j}=$ Allotted Fatalities for $j^{\text {th }}$ Structure by Generator Category $\left(A_{j} * B_{k}\right)$

$\mathrm{D}_{\mathrm{i}, \mathrm{j}}=\%$ Gen Used in $\mathrm{i}^{\text {th }}$ Zone (living space”, “basement”, "garage”, or “crawlspace) in $\mathrm{j}^{\text {th }}$ Structure

$E_{i, j, k}=$ Weighting factor for the $\mathrm{i}^{\text {th }}$ Zone in $\mathrm{j}^{\text {th }}$ Structure and the $\mathrm{k}^{\text {th }}$ restart scenario

$\mathrm{F}_{1, \mathrm{i}, \mathrm{j}}=$ Modeled Fatality Rate for Respective Current or Voluntary Standard Generator Placed in $\mathrm{i}^{\text {th }}$ Zone in $\mathrm{j}^{\text {th }}$

Structure $=\sum\left[\mathrm{D}_{\mathrm{i}, \mathrm{j}} * \mathrm{E}_{\mathrm{i}, \mathrm{j}, \mathrm{k}} *\right.$ Probability of Death $]$

where Probability of Death $=\sum$ of the binary variable for death for each 28 days $/ 28$

$\mathrm{F}_{2, \mathrm{i}, \mathrm{j}}=$ Modeled Hospitalization Rate for Respective Current or Voluntary Standard Generator Placed in the $\mathrm{i}^{\text {th }}$ Zone

in $\mathrm{j}^{\text {th }}$ Structure $=\sum\left[\mathrm{D}_{\mathrm{i}, \mathrm{j}} * \mathrm{E}_{\mathrm{i}, \mathrm{j}, \mathrm{k}} *\right.$ Probability of Hospitalization $]$

where Probability of Hospitalization $=\sum$ of the binary variable for hospitalization for each 28 days / 28

$\mathrm{F}_{3, \mathrm{i}, \mathrm{j}}=$ Modeled Treated \& Released Rate for Respective Current or Voluntary Standard Generator placed in the $\mathrm{i}^{\text {th }}$

Zone in $\mathrm{j}^{\text {th }}$ Structure $=\sum\left[\mathrm{D}_{\mathrm{i}, \mathrm{j}} * \mathrm{E}_{\mathrm{i}, \mathrm{j}, \mathrm{k}} *\right.$ Probability of Treated \& Released $]$ where Probability of Treated \& Released $=\sum$ of the binary variable for treated $\&$ released for each 28 days / 28 
$\mathrm{F}_{4, \mathrm{i}, \mathrm{j}}=$ Modeled Unlikely to Seek Treatment Rate for Respective Current or Voluntary Standard Generator Placed in

$\mathrm{i}^{\text {th }}$ Zone in $\mathrm{j}^{\text {th }}$ Structure $=\sum\left[\mathrm{D}_{\mathrm{i}, \mathrm{j}} * \mathrm{E}_{\mathrm{i}, \mathrm{j}, \mathrm{k}} *\right.$ Probability of Unlikely to Seek Treatment $]$ where Probability of Unlikely to Seek Treatment $=\sum$ of the binary variable for unlikely to seek treatment for each 28 days / 28

Details for each step in the process and the supporting rationale are given below.

\section{A.3.1 ALLOTTED FATALITIES TO EACH STRUCTURE $A_{j}=$ Allotted Fatalities for $j^{\text {th }}$ Structure (class 1 and class 2 single cylinder Generators only)}

As was done in the analysis for the NPR, in order to account for all 503 generator-related fatalities in the simulations, plus the 8 fatalities associated with generators located outdoors of a modeled structure that are new to this study, all incidents need to be assigned or allocated to the different modeled structures. Incidents that occurred in structures that exactly match the parameters of one of the NIST models will be assigned to that specific corresponding model only. Those incidents that occurred in structures that did not exactly match a modeled structure, or in situations where there was not sufficient information to completely characterize the structure, are allocated to one or more of the structures that were the closest matched based on available information. The methodology of allocation differed slightly by structure type which will be explained presently.

\section{A.3.1.1 ALLOCATION OF INCIDENT FATALITIES WITH UNMATCHED OR INCOMPLETE INFORMATION METHODOLOGY}

As a general rule, for all incidents that occurred in structures that do not exactly match the characteristic parameters of a modeled structure, the deaths will be allocated between the closest matched structures. Closest matched structure is defined as the structure or structures that match the greatest number of characteristic parameters in the same type category (e.g., incidents in detached houses were only matched to other detached houses). If more than one structure has been identified as a closest match, then the deaths will be allocated amongst the closest match structures proportional to the numbers of exact match cases. This results in numerous fractional allocations rather than allocations of whole numbers. The allocations ensure that the observed proportions remain constant. A key assumption for using this strategy is that the proportion of unknown characteristics closely matches the distribution of the known characteristics. Raking procedures for allocating unknowns based on observed proportions of knowns is a common statistical practice. The approach has been simplified and modified somewhat to account for the great variation that exists in real-world structures and the somewhat limited available selection of modeled structures. For example, if two deaths needed to be allocated to two equally closest matched structures, where structure A had six exact match deaths and structure B had two deaths, the allocation would be of the proportion 6:2 (A:B) or 3:1. Therefore, 75 percent of the two deaths to be allocated (1.5 deaths) would be allocated to structure A and 25 percent of the deaths ( 0.5$)$ to structure B. 
If a characteristic parameter for a structure involved in an incident is unknown, this parameter is automatically assumed to be unmatched. A few of the modeled structures do not have any exact match incidents. These will be allocated across all like structures proportionally to the matched counts.

If non-exact match incidents are closest matched to structures with exact matches and structures with no exact matches, then all of the incident deaths will be allocated to the structures with exact matches only. If incidents are closest matched to only structures with no exact match fatalities, then all the deaths will be allocated evenly amongst all of the closest match structures.

\section{A.3.1.2 STRUCTURE TYPE SPECIFIC CONSIDERATIONS FOR ALLOCATION OF INCIDENT DEATHS}

Detached Houses - All Characteristic Parameters Known and Exact Match to Modeled Houses For detached house incidents, an exact match is where the five incident structure characteristic parameters match exactly with one of the NIST modeled houses. Also, the garage type (integral”, "attached", or "none) must match. In these cases, all the incident fatalities will be allotted to the exact match house.

Detached Houses - All Characteristic Parameters Known But No Direct Match

If non-exact match house incidents have all known characteristic parameters, then the fatalities will be distributed proportionately amongst all modeled houses that are closest matched as described above.

Detached Houses - One or More Characteristic Parameters Unknown

Characteristic parameters that cannot be determined are considered unknown and a non-matched parameter. An exception to this rule is when it is known that there was a basement at the incident location, but whether it was a finished or unfinished basement is not known. In these cases, it will be considered to be a match to both finished and unfinished basements, but not to concrete slab or crawlspace; allocation of the incident fatalities will be performed as described. So, if there are both finished and unfinished basement closest match models, the deaths will be allocated proportionately between the two. If there is only one closest matched model, then the allocation will go to that model. If neither a matching finished or unfinished basement model are in the exact match set, then this parameter will be considered unmatched. 
Table A.3.1.1: Allocated CO Fatalities - Detached House

\begin{tabular}{|c|c|c|c|c|c|}
\hline $\begin{array}{c}\text { Matched } \\
\text { Model }\end{array}$ & $\begin{array}{l}\text { Exact Match } \\
\text { Allocations }\end{array}$ & $\begin{array}{c}\text { Partial Match } \\
\text { Allocations from “No } \\
\text { Basement" Subset* }\end{array}$ & $\begin{array}{c}\text { Partial Match } \\
\text { Allocations from } \\
\text { “Basement" Subset* }\end{array}$ & $\begin{array}{c}\text { Total } \\
\text { Allocated } \\
\text { Fatalities } \\
\end{array}$ & $\begin{array}{c}\text { Outdoor } \\
\text { Fatalities }\end{array}$ \\
\hline DH-1 & 3.0 & 6.7 & 0.0 & 9.7 & 0.0 \\
\hline DH-2 & 2.0 & 3.6 & 7.1 & 12.7 & 0.0 \\
\hline DH-2mod & 0.0 & 1.0 & 1.5 & 2.5 & 0.0 \\
\hline DH-3 & 7.0 & 11.3 & 0.0 & 18.3 & 1.3 \\
\hline DH-5 & 3.0 & 6.7 & 0.0 & 9.7 & 0.0 \\
\hline DH-7 & 5.0 & 7.5 & 10.5 & 23.0 & 1.3 \\
\hline DH-8 & 6.0 & 9.5 & 0.0 & 15.5 & 1.3 \\
\hline DH-10 & 0.0 & 2.5 & 1.5 & 4.0 & 0.0 \\
\hline DH-12 & 1.0 & 2.4 & 2.3 & 5.6 & 0.0 \\
\hline DH-19mod & 1.0 & 2.3 & 14.4 & 17.7 & 0.0 \\
\hline DH-21 & 17.0 & 14.4 & 0.0 & 31.4 & 0.0 \\
\hline DH-21mod & 3.0 & 2.9 & 0.0 & 5.9 & 1.3 \\
\hline DH-24mod & 4.0 & 1.2 & 0.0 & 5.2 & 0.0 \\
\hline DH-27 & 0.0 & 2.0 & 0.0 & 2.0 & 0.0 \\
\hline DH-32 & 0.0 & 6.0 & 0.0 & 6.0 & 1.3 \\
\hline DH-33mod & 3.0 & 3.8 & 0.3 & 7.1 & 0.0 \\
\hline DH-34 & 9.0 & 10.8 & 1.8 & 21.6 & 0.0 \\
\hline DH-41 & 0.0 & 0.5 & 5.5 & 6.0 & 0.0 \\
\hline DH-44 & 0.0 & 0.0 & 1.0 & 1.0 & 0.0 \\
\hline DH-45 & 0.0 & 1.5 & 1.5 & 3.0 & 0.0 \\
\hline DH-45mod & 1.0 & 13.8 & 18.6 & 33.4 & 0.0 \\
\hline DH-52mod & 1.0 & 1.6 & 4.4 & 7.0 & 1.3 \\
\hline DH-56 & 0.0 & 0.5 & 7.0 & 7.5 & 0.0 \\
\hline DH-60 & 1.0 & 2.0 & 6.2 & 9.2 & 0.0 \\
\hline DH-60mod & 0.0 & 2.0 & 1.5 & 3.5 & 0.0 \\
\hline DH-61 & 3.0 & 3.0 & 10.7 & 16.7 & 0.0 \\
\hline DH-61mod & 8.0 & 6.6 & 13.4 & 28.0 & 0.0 \\
\hline DH-63mod1 & 2.0 & 5.6 & 16.7 & 24.3 & 0.0 \\
\hline DH-63mod2 & 0.0 & 0.0 & 7.0 & 7.0 & 0.0 \\
\hline DH-64 & 4.0 & 5.4 & 1.6 & 11.1 & 0.0 \\
\hline DH-81 & 0.0 & 0.0 & 5.5 & 5.5 & 0.0 \\
\hline Total & 84.0 & 137.0 & 140.0 & 361.0 & 7.7 \\
\hline
\end{tabular}

* In many cases, a basement was known to be part of a house, but it was unknown if the basement was a "finished basement' or an "unfinished basement". In order to allocate "unknown basement type" incidents to only modeled houses that had basements, the allocations were handled separately for "no basement" houses and "with basement" houses. Rows and column counts may not add to totals due to rounding. 
Manufactured Houses

For NIST TN 1925, NIST used models of two manufactured houses and they will be used in this study. One modified model (MH1mod) represents manufactured houses, sometimes called mobile homes, and a previously defined house model (MH1) represents other manufactured homes. When the type of manufactured house was known, mobile home incidents will be allotted to the MH1mod model and all others to the existing manufactured home model. Cases where it was known that the house was a manufactured home, but the specific type was not known, will be proportionately allocated between the two models.

Table A.3.1.2: Allocated CO Fatalities - Manufactured House

\begin{tabular}{|c|c|c|c|c|}
\hline Matched Model & $\begin{array}{c}\text { Exact Match } \\
\text { Allocations }\end{array}$ & $\begin{array}{c}\text { Allocations for } \\
\text { Partial Matches }\end{array}$ & $\begin{array}{c}\text { Total Allocated } \\
\text { Fatalities }\end{array}$ & $\begin{array}{c}\text { Outdoor } \\
\text { Fatalities }\end{array}$ \\
\hline MH1 & 15.0 & 0.5 & 15.5 & 1.3 \\
\hline MH1mod & 63.0 & 1.5 & 64.5 & 0.0 \\
\hline Total & 78.0 & 2.0 & 80.0 & 1.3 \\
\hline
\end{tabular}

Attached Houses - All Characteristic Parameters Known and Direct Match to Model Attached house incidents will be handled similarly to detached houses with the exception that the year built parameter will not be used due to the small number of models.

Table A.3.1.3: Allocated CO Fatalities - Attached House

\begin{tabular}{|c|c|c|c|c|c|}
\hline Matched Model & $\begin{array}{c}\text { Exact Match } \\
\text { Allocations }\end{array}$ & $\begin{array}{c}\text { Partial Match } \\
\text { Allocations } \\
\text { from “No } \\
\text { Basement” } \\
\text { Subset }\end{array}$ & $\begin{array}{c}\text { Partial Match } \\
\text { Allocations } \\
\text { from } \\
\text { "Basement” } \\
\text { Subset }\end{array}$ & $\begin{array}{c}\text { Total Allocated } \\
\text { Fatalities }\end{array}$ & $\begin{array}{c}\text { Outdoor } \\
\text { Fatalities }\end{array}$ \\
\hline AH3 & 3.0 & 4.0 & 0.5 & 7.5 & 0.0 \\
\hline AH10 & 3.0 & 1.0 & 0.5 & 4.5 & 0.0 \\
\hline AH21 & 1.0 & 0.0 & 0.0 & 1.0 & 0.0 \\
\hline AH34mod & 2.0 & 0.0 & 1.0 & 3.0 & 0.0 \\
\hline Total & 9.0 & 5.0 & 2.0 & 16.0 & 0.0 \\
\hline
\end{tabular}

Detached Garages / External Structures

For NIST TN 1925, NIST developed three structures to represent various detached garages and other non-house external structures and they will be used in this study. When the size and/or configuration of the external structures were known, each incident will be assigned to the most appropriate model. In the few cases where there was no information regarding size or configuration of the external structure, the incident fatalities will be allocated proportionately to the three models based on the proportion assigned to the models. 
Table A.3.1.4: Allocated CO Fatalities - Detached Structures

\begin{tabular}{|c|c|c|c|c|}
\hline Matched Model & $\begin{array}{c}\text { Exact Match } \\
\text { Allocations }\end{array}$ & $\begin{array}{c}\text { Allocations for } \\
\text { Partial Matches }\end{array}$ & $\begin{array}{c}\text { Total Allocated } \\
\text { Fatalities }\end{array}$ & $\begin{array}{c}\text { Outdoor } \\
\text { Fatalities }\end{array}$ \\
\hline GAR1 & 11.0 & 1.9 & 12.9 & 0.0 \\
\hline GAR2 & 12.0 & 1.7 & 13.7 & 0.0 \\
\hline GAR3 & 17.0 & 2.4 & 19.4 & 0.0 \\
\hline Total & 40.0 & 6.0 & 46.0 & 0.0 \\
\hline
\end{tabular}

Due to the relatively low number of indoor fatalities while a generator was being used outdoors, only these fatalities matched to a specific house already being modeled will be simulated.

\section{A.3.2 PROPORTION OF GENERATORS INVOLVED IN FATAL CO POISONING INCIDENTS \& ALLOTTED FATALITIES FOR STRUCTURE BY GENERATOR CLASS/TYPE}

$B_{k}=\%$ by $k^{\text {th }}$ Generator Category (structure specific considerations)

$C_{j}=$ Allotted Fatalities for $j^{\text {th }}$ Structure by Gen class $\left(A_{j} * B_{k}\right)$

There are many different types and sizes of generators that have been reported to have been involved in fatal CO poisoning incidents as recorded in the CPSC incident database. The generators involved have been classified into one of four categories: Handheld, Class 1, Class 2 single cylinder, and Class 2 twin cylinder ${ }^{4}$. The majority of fatal incidents and deaths were associated with the use of Class 1 and Class 2 single cylinder generators. Because the number of fatalities associated with Handheld and Class 2 twin cylinder generators was small in relation to the Class 1 and Class 2 single cylinder generators and were only observed in three structures in the incident data, these three structures will be modeled independently. A Handheld incident occurred in a house matched to the DH8 detached house; DH8 was thus handled independently of the other detached houses. A Handheld incident also occurred in a house matched to the MH1mod manufactured home. Therefore, MH1mod and MH1 were handled independently. One fatal incident related to a Class 2 twin cylinder generator occurred in a detached structure matched to

\footnotetext{
${ }^{4}$ To arrive at the number of deaths that occurred by generator category, when the available information about the incident did not report the generator's engine displacement, staff then considered the reported wattage of the generator, if that was available. Staff classified generators with a reported wattage of $3.5 \mathrm{~kW}$ and larger as either a Class 2 single cylinder or Class 2 twin cylinder generator and those less than $3.5 \mathrm{~kW}$ as either a Handheld or Class 2 generator. To distinguish the Handheld generators from the Class 1 generators when there was no information to ascertain the engine displacement, generators with wattage $2 \mathrm{~kW}$ and larger, up to $3.5 \mathrm{~kW}$, were considered to have a Class I engine. There was only one generator with wattage below $2 \mathrm{~kW}$ in which the engine displacement could not be ascertained. That was a 1000 watt generator, which staff classified as a Handheld generator since staff's review of generators nominally in this size showed almost all as being powered by Handheld engines. To distinguish the Class 2 single cylinder generators from the Class 2 twin cylinder generators, staff found from looking at the EPA's website that twin cylinder Class II engines largely have a maximum engine power of $12 \mathrm{~kW}$ to13 kW and higher. Staff then found, from looking at manufacturers' generator specifications, that generators having engines with power equal to or greater than $12 \mathrm{~kW}$ or $13 \mathrm{~kW}$ typically have a rated power of $9 \mathrm{~kW}$ and higher. Rows and column counts may not add to totals due to rounding.
} 
GAR3. Since there were only three detached structure models, it was decided that each model (GAR1, GAR2 and GAR3) would be handled separately. Table A.3.2 below provides a summary of fatalities and allocated fatalities associated with the different generator categories by structure type.

Table A.3.2: Proportions of Generators Observed in Incident Data by Generator Category and Structure Type for Indoor Scenarios

\begin{tabular}{|c|c|c|c|c|c|}
\hline & \multicolumn{5}{|c|}{ Generator Category (\% Generator Category by Structure Type) } \\
\hline & Handheld & Class 1 & $\begin{array}{l}\text { Class } 2 \text { Single } \\
\text { Cylinder }\end{array}$ & $\begin{array}{l}\text { Class } 2 \text { Twin } \\
\text { Cylinder }\end{array}$ & $\begin{array}{c}\text { Total by } \\
\text { Structure } \\
\text { Type } \\
\end{array}$ \\
\hline $\begin{array}{c}\text { Detached } \\
\text { Houses } \\
\text { (except DH8) }\end{array}$ & $\begin{array}{c}0.0 \\
(0.0 \%)\end{array}$ & $\begin{array}{c}116.4 \\
(33.7 \%)\end{array}$ & $\begin{array}{c}229.1 \\
(66.3 \%)\end{array}$ & $\begin{array}{c}0.0 \\
(0.0 \%)\end{array}$ & $\begin{array}{c}345.5 \\
(100.0 \%)\end{array}$ \\
\hline $\begin{array}{c}\text { Detached } \\
\text { Houses - DH8 } \\
\text { only } \\
\end{array}$ & $\begin{array}{c}1.9 \\
(12.4 \%)\end{array}$ & $\begin{array}{c}4.6 \\
(29.5 \%)\end{array}$ & $\begin{array}{c}9.0 \\
(58.1 \%)\end{array}$ & $\begin{array}{c}0.0 \\
(0.0 \%)\end{array}$ & $\begin{array}{c}15.5 \\
(100.0 \%)\end{array}$ \\
\hline $\begin{array}{c}\text { Manufactured } \\
\text { Houses - } \\
\text { MH1 } \\
\end{array}$ & $\begin{array}{c}0.0 \\
(0.0 \%)\end{array}$ & $\begin{array}{c}8.8 \\
(57.1 \%)\end{array}$ & $\begin{array}{c}6.6 \\
(42.9 \%)\end{array}$ & $\begin{array}{c}0.0 \\
(0.0 \%)\end{array}$ & $\begin{array}{c}15.5 \\
(100.0 \%)\end{array}$ \\
\hline $\begin{array}{c}\text { Manufactured } \\
\text { Houses - } \\
\text { MH1mod } \\
\end{array}$ & $\begin{array}{c}1.7 \\
(2.7 \%)\end{array}$ & $\begin{array}{c}22.7 \\
(35.1 \%)\end{array}$ & $\begin{array}{c}40.1 \\
(62.2 \%)\end{array}$ & $\begin{array}{c}0.0 \\
(0.0 \%)\end{array}$ & $\begin{array}{c}64.5 \\
(100.0 \%)\end{array}$ \\
\hline $\begin{array}{c}\text { Attached } \\
\text { Houses }\end{array}$ & $\begin{array}{c}0.0 \\
(0.0 \%) \\
\end{array}$ & $\begin{array}{c}6.9 \\
(42.9 \%) \\
\end{array}$ & $\begin{array}{c}9.1 \\
(57.1 \%) \\
\end{array}$ & $\begin{array}{c}0.0 \\
(0.0 \%) \\
\end{array}$ & $\begin{array}{c}16.0 \\
(100.0 \%) \\
\end{array}$ \\
\hline $\begin{array}{c}\text { External } \\
\text { Structures - } \\
\text { GAR1 } \\
\end{array}$ & $\begin{array}{c}0.0 \\
(0.0 \%)\end{array}$ & $\begin{array}{c}6.2 \\
(48.0 \%)\end{array}$ & $\begin{array}{c}6.7 \\
(52.0 \%)\end{array}$ & $\begin{array}{c}0.0 \\
(0.0 \%)\end{array}$ & $\begin{array}{c}12.9 \\
(100.0 \%)\end{array}$ \\
\hline $\begin{array}{c}\text { External } \\
\text { Structures - } \\
\text { GAR2 } \\
\end{array}$ & $\begin{array}{c}0.0 \\
(0.0 \%)\end{array}$ & $\begin{array}{c}8.9 \\
(64.9 \%)\end{array}$ & $\begin{array}{c}4.8 \\
(35.1 \%)\end{array}$ & $\begin{array}{c}0.0 \\
(0.0 \%)\end{array}$ & $\begin{array}{c}13.7 \\
(100.0 \%)\end{array}$ \\
\hline $\begin{array}{c}\text { External } \\
\text { Structures - } \\
\text { GAR3 } \\
\end{array}$ & $\begin{array}{c}0.0 \\
(0.0 \%)\end{array}$ & $\begin{array}{c}1.8 \\
(9.4 \%)\end{array}$ & $\begin{array}{c}15.8 \\
(81.3 \%)\end{array}$ & $\begin{array}{c}1.8 \\
(9.4 \%)\end{array}$ & $\begin{array}{c}19.4 \\
(100.0 \%)\end{array}$ \\
\hline $\begin{array}{c}\text { Total by } \\
\text { Generator } \\
\text { Category }\end{array}$ & $\begin{array}{c}3.7 \\
(0.7 \%)\end{array}$ & $\begin{array}{c}176.2 \\
(35.0 \%)\end{array}$ & $\begin{array}{c}321.3 \\
(63.9 \%)\end{array}$ & $\begin{array}{c}1.8 \\
(0.4 \%)\end{array}$ & $\begin{array}{c}503.0 \\
(100.0 \%)\end{array}$ \\
\hline
\end{tabular}

\section{A.3.3 PROPORTION OF INCIDENTS BY LOCATION OF THE GENERATOR $D_{i, j}=\%$ Gen Used in $i^{\text {th }}$ Zone (living space", "basement", or "garage) in $j^{\text {th }}$ Structure}

A review of the incident data indicates that the location where consumers placed the generator within the home in fatal CO incidents was dependent on two main factors: the presence of a 
basement/crawlspace and/or a garage, and the size of the generator. The incident data indicates that consumers who use generators indoors do so for a number of reasons including: lack of knowledge of the dangers of $\mathrm{CO}$ and/or incomplete understanding of how rapidly $\mathrm{CO}$ in engine exhaust can accumulate and rise to lethal exposure levels (often a window will be left "cracked open” in an attempt to ventilate the house); fear of theft (especially in urban areas); concerns about bothering the neighbors with the noise produced by the generator; desire to hide the use of the generator from neighbors due to embarrassment at being unable to pay utility bills; not having a long enough extension cord; and attempts to comply with electrocution hazard warnings cautioning against use of the generator in wet weather.

The simulations that will be run by NIST assumes the generator will be operated in a number of modeled locations within the modeled structure, depending on structure type and configuration. The table below shows the generator locations based on the structure configurations.

Table A.3.3.1: Modeled Generator Indoor Locations Based on Structure Parameters

\begin{tabular}{|c|c|c|c|}
\hline \multicolumn{4}{|c|}{ Detached houses, manufactured houses, attached houses } \\
\hline Structure Attributes & Modeled Space 1 & Modeled Space 2 & Modeled Space 3 \\
\hline $\begin{array}{l}\text { No basement/crawl space } \\
\text { and no attached garage }\end{array}$ & $\begin{array}{l}\text { Kitchen (living } \\
\text { space) }\end{array}$ & $\begin{array}{l}\text { Bedroom farthest from } \\
\text { Master Bedroom (living } \\
\text { space) }\end{array}$ & \\
\hline $\begin{array}{l}\text { No basement/crawlspace, } \\
\text { but, attached garage }\end{array}$ & $\begin{array}{l}\text { Kitchen (living } \\
\text { space) }\end{array}$ & $\begin{array}{l}\text { Bedroom farthest from } \\
\text { Master Bedroom (living } \\
\text { space) }\end{array}$ & Attached garage \\
\hline $\begin{array}{l}\text { Basement or crawlspace, } \\
\text { but, no attached garage }\end{array}$ & $\begin{array}{l}\text { Kitchen (living } \\
\text { space) }\end{array}$ & Basement or crawlspace & \\
\hline $\begin{array}{l}\text { If basement or } \\
\text { crawlspace, and, } \\
\text { attached garage }\end{array}$ & $\begin{array}{l}\text { Kitchen (living } \\
\text { space) }\end{array}$ & Attached garage & Basement or crawlspace \\
\hline \multicolumn{4}{|c|}{ External Structures (Detached garages, etc.) } \\
\hline Structure Attributes & Modeled Space 1 & Modeled Space 2 & Modeled Space 3 \\
\hline Single room/space & $\begin{array}{l}\text { Garage Area (single } \\
\text { zone) }\end{array}$ & & \\
\hline $\begin{array}{l}\text { Two or more } \\
\text { rooms/spaces }\end{array}$ & $\begin{array}{l}\text { Garage Area (larger } \\
\text { zone) }\end{array}$ & $\begin{array}{l}\text { Workshop (smaller } \\
\text { zone) }\end{array}$ & \\
\hline
\end{tabular}

An in-depth review of the CPSC incident data indicates that there appear to be differences in where consumers place the generator given the type of structure, the characteristics of the structure, and the size (category) of the generator. It is intuitively obvious that if a generator were used indoors in a house that has neither garage nor basement, then the location of the generator would be in the living space. But differences as to where consumers tend to use a generator seem to appear when the consumer has different location choices, e.g., basement and/or garage/crawlspace in addition to the living space. This choice may also be dependent on the 
generator category, possibly due to the physical size of the generator. For example, in houses with a garage and no basement, for Class 1 generators, $76.9 \%$ of the fatalities occurred with generator used in the living space and $23.1 \%$ when used in the garage. Conversely, in houses with a garage and no basement, for (physically larger) Class 2 single cylinder generators, only $26.4 \%$ of the fatalities occurred with generator used in the living space while $73.6 \%$ occurred when used in the garage.

Table A.3.3.2 presents the houses modeled grouped by their similar structural features.

Table A.3.3.2. Houses Grouped by Similar Structural Features

\begin{tabular}{|c|c|c|l|}
\hline Basement & Crawlspace & Garage & \multicolumn{1}{|c|}{ House models } \\
\hline $\mathrm{N}$ & $\mathrm{N}$ & $\mathrm{N}$ & DH-21, DH-21(mod), DH-24(mod), DH-34, AH-3 \\
\hline $\mathrm{N}$ & $\mathrm{Y}$ & $\mathrm{N}$ & MH-1(mod), DH-3, MH-1 \\
\hline $\mathrm{Y}$ & $\mathrm{N}$ & $\mathrm{N}$ & $\begin{array}{l}\text { DH-61, DH-63 (mod1), DH-61, DH-56, DH-63(mod2), DH-41, } \\
\text { DH-81, DH-27, DH-44, AH-10 }\end{array}$ \\
\hline $\mathrm{N}$ & $\mathrm{N}$ & $\mathrm{Y}$ & DH-8, DH-64, DH-5, DH-1, DH-33(mod), DH-32 \\
\hline $\mathrm{Y}$ & $\mathrm{N}$ & $\mathrm{Y}$ & $\begin{array}{l}\text { DH-45(mod), DH-7, DH-19(mod), DH-2, DH-60, DH-52(mod), } \\
\text { DH-12, DH-10, DH-60(mod), DH-45, DH-2(mod), AH-34(mod), } \\
\text { AH-21 }\end{array}$ \\
\hline
\end{tabular}

Specific assumed probabilities of the restart scenarios are given in the appropriate tables in Section 4 of the report, Tables 2.a. through 8.b.ii. It should be noted that with current generators on the market where sufficient data is available, the different scenarios are given equal weighting. The optional restart scenarios are:

- No restart attempted,

- Restart in place,

- Move to other more isolated area and restart, or

- Move to an outside location and restart.

Within these scenarios there are numerous location specific optional changes to the running environment which include, but are not limited to, window position, garage bay door position, and exhaust orientation.

The following tables present a summary of proportions of fatalities which occurred with generator locations based on structure type and generator category. Note that due to the limited number of attached house cases, for purposes of generator locations, generators were treated together. This was also done for the detached structures GAR1 and GAR2. 
Table A.3.3.4: Proportions of Fatalities Based on Indoor Generator Locations Detached House - Class 1 Generators - By Structure Type (121.0 allocated fatalities)

\begin{tabular}{|c|c|c|c|c|c|}
\hline Foundation & Garage & living space & basement & crawlspace & garage \\
\hline No basement & No garage & $100.0 \%$ & n/a & n/a & n/a \\
\hline No basement & Garage & $76.9 \%$ & n/a & n/a & $23.1 \%$ \\
\hline Crawlspace & No garage & $73.4 \%$ & $\mathrm{n} / \mathrm{a}$ & $26.6 \%$ & $\mathrm{n} / \mathrm{a}$ \\
\hline Crawlspace $^{+}$ & Garage & -- & $\mathrm{n} / \mathrm{a}$ & -- & -- \\
\hline Basement & No garage & $39.3 \%$ & $60.7 \%$ & $\mathrm{n} / \mathrm{a}$ & $\mathrm{n} / \mathrm{a}$ \\
\hline Basement & Garage & $29.5 \%$ & $44.0 \%$ & $\mathrm{n} / \mathrm{a}$ & $26.5 \%$ \\
\hline
\end{tabular}

"n/a" indicates this location is not applicable to the structure configuration.

+ There were no instances in the incident data of a Class 1 generator used in a detached house with a crawlspace and a garage.

Table A.3.3.5: Proportions of Fatalities Based on Indoor Generator Locations - Detached House - Class 2 single cylinder Generators - By Structure Type (238.1 allocated fatalities)

\begin{tabular}{|c|c|c|c|c|c|}
\hline Foundation & Garage & living space & basement & crawlspace & garage \\
\hline No basement & No garage & $100.0 \%$ & n/a & n/a & n/a \\
\hline No basement & Garage & $26.4 \%$ & n/a & n/a & $73.6 \%$ \\
\hline Crawlspace & No garage & $100.0 \%$ & $\mathrm{n} / \mathrm{a}$ & $0.0 \%$ & $\mathrm{n} / \mathrm{a}$ \\
\hline Crawlspace & Garage & $0.0 \%$ & $\mathrm{n} / \mathrm{a}$ & $40.0 \%$ & $60.0 \%$ \\
\hline Basement & No garage & $27.3 \%$ & $72.7 \%$ & $\mathrm{n} / \mathrm{a}$ & $\mathrm{n} / \mathrm{a}$ \\
\hline Basement & Garage & $0.0 \%$ & $20.6 \%$ & $\mathrm{n} / \mathrm{a}$ & $79.4 \%$ \\
\hline
\end{tabular}

Table A.3.3.6: Proportions of Fatalities Based on Indoor Generator Locations - Detached House (DH8 only) - Handheld Generators (1.9 allocated fatalities)

\begin{tabular}{|c|c|c|c|c|c|}
\hline Foundation & Garage & living space & basement & crawlspace & garage \\
\hline No basement & Garage & $26.4 \%$ & n/a & n/a & $73.6 \%$ \\
\hline
\end{tabular}

Table A.3.3.7: Allocated Fatalities and Proportions of Fatalities Based on Indoor Generator Locations - Manufactured Homes - Handheld Generators - By Structure Type

\begin{tabular}{|c|c|c|c|}
\hline Structure Type & Allocated Fatalities & living space & Basement/crawlspace \\
\hline Mobile Home & 1.7 & $100.0 \%$ & $\mathrm{n} / \mathrm{a}$ \\
\hline $\begin{array}{c}\text { Other Manufactured } \\
\text { Homes }\end{array}$ & 0 & $\mathrm{n} / \mathrm{a}$ & $\mathrm{n} / \mathrm{a}$ \\
\hline
\end{tabular}


Table A.3.3.8: Allocated Fatalities and Proportions of Fatalities Based on Indoor Generator Locations - Manufactured Homes - Class 1 Generators - By Structure Type

\begin{tabular}{|c|c|c|c|}
\hline Structure Type & Allocated Fatalities & living space & Basement/crawlspace \\
\hline Mobile Home & 22.7 & $100.0 \%$ & $\mathrm{n} / \mathrm{a}$ \\
\hline $\begin{array}{c}\text { Other Manufactured } \\
\text { Homes }\end{array}$ & 8.8 & $100.0 \%$ & $\mathrm{n} / \mathrm{a}$ \\
\hline
\end{tabular}

Table A.3.3.9: Allocated Fatalities and Proportions of Fatalities Based on Indoor Generator Locations - Manufactured Homes - Class 2 single cylinder Generators - By Structure Type

\begin{tabular}{|c|c|c|c|}
\hline Structure Type & Allocated Fatalities & living space & Basement/crawlspace \\
\hline Mobile Home & 40.1 & $97.5 \%$ & $2.5 \%$ \\
\hline $\begin{array}{c}\text { Other Manufactured } \\
\text { Homes }\end{array}$ & 6.6 & $66.7 \%$ & $33.3 \%$ \\
\hline
\end{tabular}

Table A.3.3.10: Allocated Fatalities and Proportions of Fatalities Based on Indoor Generator Locations, Structure Model and Generator Category - Attached House - All Generator Categories

\begin{tabular}{|c|c|c|c|c|}
\hline $\begin{array}{c}\text { Structure } \\
\text { Model }\end{array}$ & Allocated Fatalities & Living Space & Basement & Garage \\
\hline AH10 & 4.5 & $66.7 \%$ & $33.3 \%$ & $\mathrm{n} / \mathrm{a}$ \\
\hline AH21 & 1.0 & $0.0 \%$ & $20.0 \%$ & $80.0 \%$ \\
\hline AH3 & 7.5 & $100.0 \%$ & $\mathrm{n} / \mathrm{a}$ & $\mathrm{n} / \mathrm{a}$ \\
\hline AH34mod & 3.0 & $0.0 \%$ & $20.0 \%$ & $80.0 \%$ \\
\hline
\end{tabular}

Table A.3.3.11: Allocated Fatalities and Proportions of Fatalities Based on Indoor Generator Locations, Structure Type and Generator Type - Detached Structure - All Generator Categories - GAR1 and GAR2

\begin{tabular}{|c|c|c|c|}
\hline $\begin{array}{c}\text { Structure } \\
\text { Model }\end{array}$ & Allocated Fatalities & $\begin{array}{c}\text { Garage Area/Larger } \\
\text { Room }\end{array}$ & Workshop/Smaller Room \\
\hline GAR1 & 12.9 & $100.0 \%$ & n/a \\
\hline GAR2 & 13.7 & $100.0 \%$ & n/a \\
\hline
\end{tabular}

Table A.3.3.12: Proportions of Fatalities Based on Indoor Generator Locations and Generator Category - Detached Structure - GAR3 (19.4 fatalities)

\begin{tabular}{|c|c|c|}
\hline Generator Category & Garage/Larger Room & Workshop/Smaller Room \\
\hline Class 1 & $12.5 \%$ & $87.5 \%$ \\
\hline Class 2 single cylinder & $51.6 \%$ & $48.4 \%$ \\
\hline Class 2 twin cylinder & $75.0 \%$ & $25.0 \%$ \\
\hline
\end{tabular}




\section{A.3.4 RESTART SCENARIOS}

Tables 2.a. to 8.b.ii. in the main body of this report summarize the restart scenarios and their associated probabilities. Since there are few generators that comply with either of the voluntary standards on the market, and staff is not aware of any available incident data that may inform the actual probabilities, CPSC staff decided to assign equal probability to each restart scenario and restart sub-scenario within the observed probabilities of initial location of the generator within the structure. Sub-scenarios are defined as secondary restart location where there are multiple optional usage characteristics. For example, a generator initially started in one area of the house may be moved to a garage before the consumer attempts to restart it. In this case, there are two different sub-scenarios:

- Restart with the garage door open or closed, (1/2 probability each), and

- Restart with the generator exhaust pointed, generally, away from the wall containing the interior door (3/4 probability) or pointing toward the wall containing the interior door (1/4 probability).

All of these scenario probabilities (weights) and sub-scenarios probabilities (sub-weights) are combined together such that the sum equals one with the exception of, in some cases, the exhaust orientation. In these cases, in these cases, the orientation would be weighted 3/4 away from a wall with door and $1 / 4$ toward the wall with a door as in the example above.

\section{A.3.5 OUTDOOR SCENARIOS}

In addition to the $503 \mathrm{CO}$ fatalities associated with structures included in this analysis, the incident data also included eight $\mathrm{CO}$ fatalities where an outdoor-located generator caused fatalities within fixed residential structures matching those included in this study. In these cases, although the consumer may have thought that their placement of the generator outside of a confined space would prevent $\mathrm{CO}$ buildup inside their home, fatal levels of $\mathrm{CO}$ managed to enter and accumulate within the home. (There were additional deaths from outside use of generators, but the structure where the victims were located do not match any of the structures in NIST's inventory of building models.) Six of the 8 deaths could be associated with model-specific structures. For two of the deaths, it was only known that the incident occurred in a house, but no specific structural information was available. Since only a few different home types were associated with the CO deaths, the two unknown home type fatalities were allocated to just the six home designs that were known to have outdoor-located generator fatalities within the home. Table A.3.5 below lists the involved house designs and the allocated $\mathrm{CO}$ fatalities. Note that this information repeats information contained in Tables A.3.1.1 and A.3.1.2. 
Table A.3.5: Allocated Outdoor Generator CO Fatalities

\begin{tabular}{|c|c|}
\hline Matched Model & $\begin{array}{c}\text { Outdoor } \\
\text { Fatalities }\end{array}$ \\
\hline DH-3 & 1.3 \\
\hline DH-7 & 1.3 \\
\hline DH-8 & 1.3 \\
\hline DH-21mod & 1.3 \\
\hline DH-32 & 1.3 \\
\hline DH-52mod & 1.3 \\
\hline Total & 8.0 \\
\hline
\end{tabular}

\section{A.3.6 CPSC STAFF EFFECTIVENESS ESTIMATES}

NIST will simulate the generator characteristics provided in Table 11 in the body of this report based on a number of factors including:

- Structure design,

- Location of the generator in the structure (structure design dependent),

- Generator runtime (generator type specific, assumed full tank, no refill),

- Exposure duration of up to 24 hours, estimated using one-second simulation time steps with one-minute output resolution, starting at 12:00 a.m.,

- The simulations will be run for 28 individual days using historic weather data recorded at three different geographic locations and three different temperature ranges to approximate the distribution of incidents observed in the CPSC incident data at a generalized level (see Table 9 in the body of the report).

- Although the weather file data was chosen from consecutive days for the different seasons/locations, each simulated day was treated as a standalone event with no carryover effect from the previous day (i.e., each of the day's simulation is not affected by the previous day's results.)

The one-minute CO concentrations generated by the NIST simulations will be used to calculate $\mathrm{COHb}$ profiles for an occupant in each occupiable zone as described in Section 8 of the main body of this report and to determine if, and when, a fatal scenario is predicted based on four criteria developed by CPSC Health Sciences (HS) staff for interpretation of modeled COHb values. The determination of fatalities will be made on a zone-by-zone basis. As was done for the benefits analysis of the NPR, the four criteria used to interpret predicted fatal COHb profiles are:

1. If peak level is $\geq 60 \% \mathrm{COHb}$, assume death.

2. If peak level is $\geq 50 \% \mathrm{COHb}$ but $<60 \%$, assume death unless average duration of elevation $>50 \% \mathrm{COHb}$ is less than 2 hours, and average duration of elevation between $\geq 40 \%$ and $<50 \% \mathrm{COHb}$ is less than 4 hours. 
3. If peak level is $\geq 40 \% \mathrm{COHb}$, but $<50 \% \mathrm{COHb}$, assume death if duration of the average in this range exceeds 6 hours.

4. If peak level is $\leq 40 \% \mathrm{COHb}$, assume survival.

The results of this assessment, for a given day, of $\mathrm{COHb}$ levels yields a binary result where $1=$ death or $0=$ survival.

In addition to the simulated fatalities analysis, CPSC HS staff developed criteria for estimating potential severity of injuries for the survivors of formally fatal exposures. The injury level determination also will employ the calculated COHb levels as in CPSC staff's fatality assessment as follows:

1. $<15 \% \mathrm{COHb}=$ minimal if any perceptible symptoms in healthy adults - unlikely to seek medical treatment

2. $15 \% \mathrm{COHb}$ and $<25 \% \mathrm{COHb}=$ likely to perceive adverse symptoms and to seek medical evaluation (in emergency room (ER) or other medical setting), but likely to be released without need for hospitalization or transfer to a hyperbaric oxygen (HBO) ${ }^{5}$ treatment facility or other specialized treatment center

3. $25 \% \mathrm{COHb}$ but $<40 \% \mathrm{COHb}$ for $6 \mathrm{~h}=$ likely to perceive adverse symptoms and to seek or be taken for medical evaluation (in ER or other medical setting) and likely to be hospitalized or transferred to an HBO-treatment facility or other specialized treatment center

Like the fatality assessment above, levels of injuries also yield a binary variable for each given day. It should be noted that for any given day, there is only one outcome. The potential victim will either be a fatality, be hospitalized, be treated and released, or will not seek medical treatment.

In order to estimate the proportion of fatalities for a given scenario, the following assumptions regarding exposure to generator produced $\mathrm{CO}$ will be used:

1) Each of the 28 simulated days will be treated as a separate event with no carry-over effect from previous runs. The possible outcome at any given point in time for the potential victim would be a binary variable, either survival (0) or death (1). Therefore, the average of the outcomes over all 28 days would be the probability of death for the purposes of this analysis. Similar analyses will be performed for potential injuries.

\footnotetext{
${ }^{5}$ A HBO chamber is a facility used for exposing patients to 100 percent oxygen under supra-atmospheric conditions to shorten the time it otherwise normally takes for the $\mathrm{CO}$ to leave the bloodstream and to increase the amount of oxygen dissolved in the blood. A broad set of recommendations has been established for HBO treatment for CO poisoning, which includes a $\mathrm{COHb}$ level above 25 percent, loss of consciousness, severe metabolic acidosis, victims with symptoms such as persistent chest pain or altered mental status, and pregnant women. Treatment is not recommended for mild-to-moderate CO poisoning victims, other than for those at risk of adverse outcomes (Clardy et. al. 2010).
} 
2) Generator locations within the house/structure are proportionately equal to incident data.

3) Intervention probabilities are assumed to have equal probability over 24-hour period. This assumption will be used because, frequently, it was unknown how long of an interval between when the generator was started and when the victim died or some other type of intervention occurred based on the incident data.

4) The victim's location in the structure is assumed to have equal probability of occurring in any living space room. This assumption will be made for two reasons. In multi-fatality incidents, victims were often found in different locations within a structure. Also, it was frequently unclear whether victims were located in the single area in which they were found for the entire time.

The following four tables present the summary of the simulated proportion of fatalities associated with the location of the generator, based on the incident data. For Class 1 and Class 2 single cylinder generators, the proportions are based on all structures of similar configurations. For Handheld and Class 2 twin cylinder generators, the proportions are based on the few actual incidents as reported in the CPSC incident data. 
Table A.3.6.1.1: Class 1 Generator Placement Location Proportions

\begin{tabular}{|c|c|c|c|c|c|c|c|c|}
\hline \multicolumn{4}{|c|}{ Class I Generators } & \multicolumn{5}{|c|}{ Generator Location } \\
\hline NIST Model & $\begin{array}{c}\text { Allocated } \\
\text { Deaths - All } \\
\text { Gens }\end{array}$ & Proportion & $\begin{array}{l}\text { Allocated } \\
\text { Deaths }\end{array}$ & $\begin{array}{l}\text { Living } \\
\text { Space }\end{array}$ & Basement & $\begin{array}{l}\text { Crawl- } \\
\text { space }\end{array}$ & $\begin{array}{c}\text { Attached } \\
\text { Garage / } \\
\text { Garage Area }\end{array}$ & Workshop \\
\hline AH10 & 4.5 & $42.9 \%$ & 1.9 & $66.7 \%$ & $33.3 \%$ & & & \\
\hline AH21 & 1.0 & $42.9 \%$ & 0.4 & $0.0 \%$ & $20.0 \%$ & & $80.0 \%$ & \\
\hline AH3 & 7.5 & $42.9 \%$ & 3.2 & $100.0 \%$ & & & & \\
\hline AH34mod & 3.0 & $42.9 \%$ & 1.3 & $0.0 \%$ & $20.0 \%$ & & $80.0 \%$ & \\
\hline DH-1 & 9.7 & $33.7 \%$ & 3.3 & $76.9 \%$ & & & $23.1 \%$ & \\
\hline DH-10 & 4.0 & $33.7 \%$ & 1.3 & $29.5 \%$ & $44.0 \%$ & & $26.5 \%$ & \\
\hline DH-12 & 5.6 & $33.7 \%$ & 1.9 & $29.5 \%$ & $44.0 \%$ & & $26.5 \%$ & \\
\hline DH-19mod & 17.7 & $33.7 \%$ & 6.0 & $29.5 \%$ & $44.0 \%$ & & $26.5 \%$ & \\
\hline DH-2 & 12.7 & $33.7 \%$ & 4.3 & $29.5 \%$ & $44.0 \%$ & & $26.5 \%$ & \\
\hline DH-21 & 31.4 & $33.7 \%$ & 10.6 & $100.0 \%$ & & & & \\
\hline DH-21mod & 5.9 & $33.7 \%$ & 2.0 & $100.0 \%$ & & & & \\
\hline DH-24mod & 5.2 & $33.7 \%$ & 1.7 & $100.0 \%$ & & & & \\
\hline DH-27 & 2.0 & $33.7 \%$ & 0.7 & $39.3 \%$ & $60.7 \%$ & & & \\
\hline DH-2mod & 2.5 & $33.7 \%$ & 0.8 & $29.5 \%$ & $44.0 \%$ & & $26.5 \%$ & \\
\hline DH-3 & 18.3 & $33.7 \%$ & 6.2 & $73.4 \%$ & & $26.6 \%$ & & \\
\hline DH-32 & 6.0 & $33.7 \%$ & 2.0 & $76.9 \%$ & & & $23.1 \%$ & \\
\hline DH-33mod & 7.1 & $33.7 \%$ & 2.4 & $76.9 \%$ & & & $23.1 \%$ & \\
\hline DH-34 & 21.6 & $33.7 \%$ & 7.3 & $100.0 \%$ & & & & \\
\hline DH-41 & 6.0 & $33.7 \%$ & 2.0 & $39.3 \%$ & $60.7 \%$ & & & \\
\hline DH-44 & 1.0 & $33.7 \%$ & 0.3 & $29.5 \%$ & $44.0 \%$ & & $26.5 \%$ & \\
\hline DH-45 & 3.0 & $33.7 \%$ & 1.0 & $29.5 \%$ & $44.0 \%$ & & $26.5 \%$ & \\
\hline DH-45mod & 33.4 & $33.7 \%$ & 11.3 & $29.5 \%$ & $44.0 \%$ & & $26.5 \%$ & \\
\hline DH-5 & 9.7 & $33.7 \%$ & 3.3 & $76.9 \%$ & & & $23.1 \%$ & \\
\hline DH-52mod & 7.0 & $33.7 \%$ & 2.4 & $29.5 \%$ & $44.0 \%$ & & $26.5 \%$ & \\
\hline DH-56 & 7.5 & $33.7 \%$ & 2.5 & $39.3 \%$ & $60.7 \%$ & & & \\
\hline DH-60 & 9.2 & $33.7 \%$ & 3.1 & $29.5 \%$ & $44.0 \%$ & & $26.5 \%$ & \\
\hline DH-60mod & 3.5 & $33.7 \%$ & 1.2 & $29.5 \%$ & $44.0 \%$ & & $26.5 \%$ & \\
\hline DH-61 & 16.7 & $33.7 \%$ & 5.6 & $39.3 \%$ & $60.7 \%$ & & & \\
\hline DH-61mod & 28.0 & $33.7 \%$ & 9.4 & $39.3 \%$ & $60.7 \%$ & & & \\
\hline DH-63mod1 & 24.3 & $33.7 \%$ & 8.2 & $39.3 \%$ & $60.7 \%$ & & & \\
\hline DH-63mod2 & 7.0 & $33.7 \%$ & 2.4 & $39.3 \%$ & $60.7 \%$ & & & \\
\hline DH-64 & 11.1 & $33.7 \%$ & 3.7 & $76.9 \%$ & & & $23.1 \%$ & \\
\hline DH-7 & 23.0 & $33.7 \%$ & 7.8 & $29.5 \%$ & $44.0 \%$ & & $26.5 \%$ & \\
\hline DH-8 & 15.5 & $29.5 \%$ & 4.6 & $76.9 \%$ & & & $23.1 \%$ & \\
\hline DH-81 & 5.5 & $33.7 \%$ & 1.9 & $39.3 \%$ & $60.7 \%$ & & & \\
\hline GAR1 & 12.9 & $48.0 \%$ & 6.2 & & & & $100.0 \%$ & \\
\hline GAR2 & 13.7 & $64.9 \%$ & 8.9 & & & & $100.0 \%$ & \\
\hline GAR3 & 19.4 & $9.4 \%$ & 1.8 & & & & $12.5 \%$ & $87.5 \%$ \\
\hline MH1 & 15.5 & $57.1 \%$ & 8.8 & $100.0 \%$ & & $0.0 \%$ & & \\
\hline MH1mod & 64.5 & $35.1 \%$ & 22.7 & $100.0 \%$ & & $0.0 \%$ & & \\
\hline Total & & & 176.2 & & & & & \\
\hline
\end{tabular}

Note: No value in the Generator Location field indicates that this zone is not present in the specific model. 
Table A.3.6.1.2: Class 2 Single Cylinder Generator Placement Location Proportions

\begin{tabular}{|c|c|c|c|c|c|c|c|c|}
\hline \multicolumn{4}{|c|}{ Class 2 Single Cylinder Generators } & \multicolumn{5}{|c|}{ Generator Location } \\
\hline NIST Model & $\begin{array}{c}\text { Allocated } \\
\text { Deaths - All } \\
\text { Gens }\end{array}$ & Proportion & $\begin{array}{l}\text { Allocated } \\
\text { Deaths }\end{array}$ & $\begin{array}{l}\text { Living } \\
\text { Space }\end{array}$ & Basement & $\begin{array}{l}\text { Crawl- } \\
\text { space }\end{array}$ & $\begin{array}{c}\text { Attached } \\
\text { Garage / } \\
\text { Garage Area }\end{array}$ & Workshop \\
\hline AH10 & 4.5 & $57.1 \%$ & 2.6 & $66.7 \%$ & $33.3 \%$ & & & \\
\hline AH21 & 1.0 & $57.1 \%$ & 0.6 & $0.0 \%$ & $20.0 \%$ & & $80.0 \%$ & \\
\hline AH3 & 7.5 & $57.1 \%$ & 4.3 & $100.0 \%$ & & & & \\
\hline AH34mod & 3.0 & $57.1 \%$ & 1.7 & $0.0 \%$ & $20.0 \%$ & & $80.0 \%$ & \\
\hline DH-1 & 9.7 & $66.3 \%$ & 6.4 & $26.4 \%$ & & & $73.6 \%$ & \\
\hline DH-10 & 4.0 & $66.3 \%$ & 2.7 & $0.0 \%$ & $20.6 \%$ & & $79.4 \%$ & \\
\hline DH-12 & 5.6 & $66.3 \%$ & 3.7 & $0.0 \%$ & $20.6 \%$ & & $79.4 \%$ & \\
\hline DH-19mod & 17.7 & $66.3 \%$ & 11.7 & $0.0 \%$ & $20.6 \%$ & & $79.4 \%$ & \\
\hline DH-2 & 12.7 & $66.3 \%$ & 8.4 & $0.0 \%$ & $20.6 \%$ & & $79.4 \%$ & \\
\hline DH-21 & 31.4 & $66.3 \%$ & 20.8 & $100.0 \%$ & & & & \\
\hline DH-21mod & 5.9 & $66.3 \%$ & 3.9 & $100.0 \%$ & & & & \\
\hline DH-24mod & 5.2 & $66.3 \%$ & 3.4 & $100.0 \%$ & & & & \\
\hline DH-27 & 2.0 & $66.3 \%$ & 1.3 & $27.3 \%$ & $72.7 \%$ & & & \\
\hline DH-2mod & 2.5 & $66.3 \%$ & 1.7 & $0.0 \%$ & $20.6 \%$ & & $79.4 \%$ & \\
\hline DH-3 & 18.3 & $66.3 \%$ & 12.2 & $100.0 \%$ & & $0.0 \%$ & & \\
\hline DH-32 & 6.0 & $66.3 \%$ & 4.0 & $26.4 \%$ & & & $73.6 \%$ & \\
\hline DH-33mod & 7.1 & $66.3 \%$ & 4.7 & $26.4 \%$ & & & $73.6 \%$ & \\
\hline DH-34 & 21.6 & $66.3 \%$ & 14.3 & $100.0 \%$ & & & & \\
\hline DH-41 & 6.0 & $66.3 \%$ & 4.0 & $27.3 \%$ & $72.7 \%$ & & & \\
\hline DH-44 & 1.0 & $66.3 \%$ & 0.7 & $0.0 \%$ & $20.6 \%$ & & $79.4 \%$ & \\
\hline DH-45 & 3.0 & $66.3 \%$ & 2.0 & $0.0 \%$ & $20.6 \%$ & & $79.4 \%$ & \\
\hline DH-45mod & 33.4 & $66.3 \%$ & 22.1 & $0.0 \%$ & $20.6 \%$ & & $79.4 \%$ & \\
\hline DH-5 & 9.7 & $66.3 \%$ & 6.5 & $26.4 \%$ & & & $73.6 \%$ & \\
\hline DH-52mod & 7.0 & $66.3 \%$ & 4.6 & $0.0 \%$ & $20.6 \%$ & & $79.4 \%$ & \\
\hline DH-56 & 7.5 & $66.3 \%$ & 5.0 & $27.3 \%$ & $72.7 \%$ & & & \\
\hline DH-60 & 9.2 & $66.3 \%$ & 6.1 & $0.0 \%$ & $20.6 \%$ & & $79.4 \%$ & \\
\hline DH-60mod & 3.5 & $66.3 \%$ & 2.3 & $0.0 \%$ & $20.6 \%$ & & $79.4 \%$ & \\
\hline DH-61 & 16.7 & $66.3 \%$ & 11.1 & $27.3 \%$ & $72.7 \%$ & & & \\
\hline DH-61mod & 28.0 & $66.3 \%$ & 18.5 & $27.3 \%$ & $72.7 \%$ & & & \\
\hline DH-63mod1 & 24.3 & $66.3 \%$ & 16.1 & $27.3 \%$ & $72.7 \%$ & & & \\
\hline DH-63mod2 & 7.0 & $66.3 \%$ & 4.6 & $27.3 \%$ & $72.7 \%$ & & & \\
\hline DH-64 & 11.1 & $66.3 \%$ & 7.3 & $26.4 \%$ & & & $73.6 \%$ & \\
\hline DH-7 & 23.0 & $66.3 \%$ & 15.3 & $0.0 \%$ & $20.6 \%$ & & $79.4 \%$ & \\
\hline DH-8 & 15.5 & $58.1 \%$ & 9.0 & $26.4 \%$ & & & $73.6 \%$ & \\
\hline DH-81 & 5.5 & $66.3 \%$ & 3.6 & $27.3 \%$ & $72.7 \%$ & & & \\
\hline GAR1 & 12.9 & $52.0 \%$ & 6.7 & & & & $100.0 \%$ & \\
\hline GAR2 & 13.7 & $35.1 \%$ & 4.8 & & & & $100.0 \%$ & \\
\hline GAR3 & 19.4 & $81.3 \%$ & 15.8 & & & & $51.6 \%$ & $48.4 \%$ \\
\hline MH1 & 15.5 & $42.9 \%$ & 6.6 & $66.7 \%$ & & $33.3 \%$ & & \\
\hline MH1mod & 64.5 & $62.2 \%$ & 40.1 & $100.0 \%$ & & $0.0 \%$ & & \\
\hline Total & & & 321.3 & & & & & \\
\hline
\end{tabular}

Note: No value in the Generator Location field indicates that this zone is not present in the specific model. 
Table A.3.6.1.3: Handheld Generator Placement Location Proportions

\begin{tabular}{|c|c|c|c|c|c|c|c|c|}
\hline \multicolumn{4}{|c|}{ Handheld Generators } & \multicolumn{5}{|c|}{ Generator Location } \\
\hline NIST Model & $\begin{array}{c}\text { Allocated } \\
\text { Deaths - All } \\
\text { Gens }\end{array}$ & Proportion & $\begin{array}{c}\text { Allocated } \\
\text { Deaths }\end{array}$ & $\begin{array}{l}\text { Living } \\
\text { Space }\end{array}$ & Basement & $\begin{array}{c}\text { Crawl- } \\
\text { space }\end{array}$ & $\begin{array}{c}\text { Attached } \\
\text { Garage }\end{array}$ & Workshop \\
\hline MH1mod & 64.5 & $2.7 \%$ & 1.7 & $100.0 \%$ & & $0.0 \%$ & & \\
\hline DH-8 & 15.5 & $12.4 \%$ & 1.9 & $100.0 \%$ & & & $0.0 \%$ & \\
\hline Total & & & 3.7 & & & & & \\
\hline
\end{tabular}

Note: No value in the Generator Location field indicates that this zone is not present in the specific model.

Table A.3.6.1.4: Class 2 Twin Cylinder Generator Placement Location Proportions

\begin{tabular}{|l|c|c|c|c|c|c|c|}
\hline \multicolumn{4}{|c|}{ Class 2 Twin Cylinder Generators } & \multicolumn{3}{c|}{ Generator Location } \\
\hline NIST Model & $\begin{array}{c}\text { Allocated } \\
\text { Deaths - All } \\
\text { Gens }\end{array}$ & $\%$ TC & $\begin{array}{c}\text { Allocated } \\
\text { Deaths }\end{array}$ & $\begin{array}{c}\text { Living } \\
\text { Space }\end{array}$ & Basement & $\begin{array}{c}\text { Crawl- } \\
\text { space }\end{array}$ & $\begin{array}{c}\text { Garage area } \\
\text { Workshop }\end{array}$ \\
\hline GAR3 & 19.4 & $9.4 \%$ & 1.8 & & & & $75.0 \%$ \\
\hline Total & & & 1.8 & & & & $25.0 \%$ \\
\hline
\end{tabular}

Note: No value in the Generator Location field indicates that this zone is not present in the specific model. 